\title{
LEAN ERP SYSTEMS: EXISTENCE AND VIABILITY IN TODAY'S MANUFACTURING INDUSTRY
}

\author{
A Thesis \\ presented to \\ the Faculty of California Polytechnic State University, \\ San Luis Obispo
}

\author{
In Partial Fulfillment \\ of the Requirements for the Degree \\ Master of Science in Industrial Engineering
}

by

Miroslav Djuric

December 2008 
(C) 2008

Miroslav Djuric

\section{ALL RIGHTS RESERVED}




\section{COMMITTEE MEMBERSHIP}

TITLE:

LEAN ERP SYSTEMS: EXISTENCE AND VIABILITY

IN TODAY'S MANUFACTURING INDUSTRY
AUTHOR:
Miroslav Djuric
DATE SUBMITTED: $\quad$ December 2008
COMMITTE CHAIR: Unny Menon, Ph.D.

COMMITTEE MEMBER: $\quad$ Roya Javadpour, Ph.D.

COMMITEE MEMBER: $\quad$ Reza Pouraghabagher, Ph.D. 


\section{ABSTRACT \\ LEAN ERP SYSTEMS: EXISTENCE AND VIABILITY IN TODAY'S MANUFACTURING INDUSTRY \\ Miroslav Djuric}

This thesis evaluates the existence and viability of lean ERP systems in today's manufacturing industry. Results from the research show that current practitioners of lean - who also utilize ERP systems - do not have a strong enough link between the two to consider their ERP systems, and overall organizations, as being truly lean.

Few articles and research papers in today's body of knowledge contain information on the concept of lean ERP. A survey, sent to numerous industry professionals and posted on lean manufacturing websites, provided the results necessary for statistical analysis. The conclusions obtained from this survey analysis provided a strong foundation for additional, more focused, research of lean ERP systems. 


\section{Table of Contents}

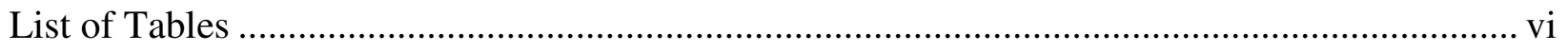

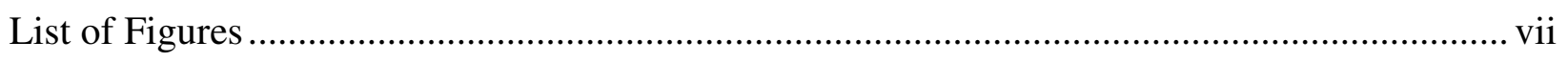

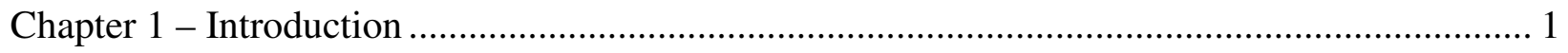

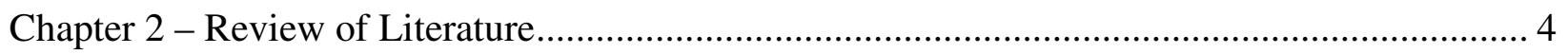

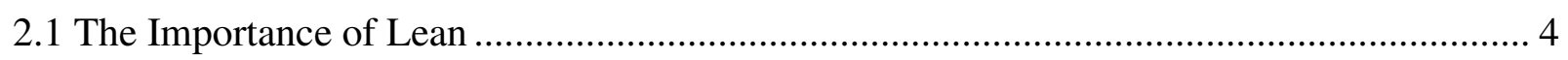

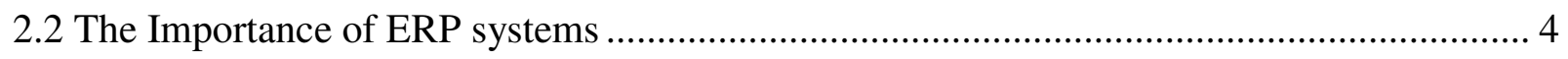

2.3 Implementations of Lean and ERP .......................................................................... 5

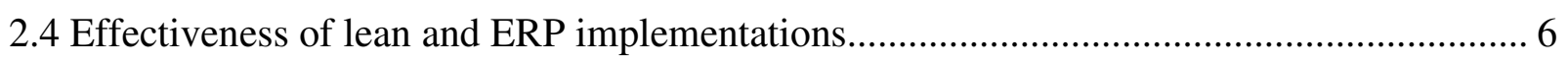

2.5 The Survey and its Relation to Current Literature ....................................................... 8

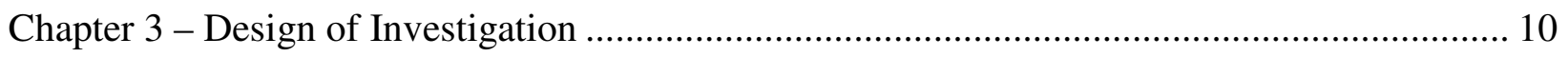

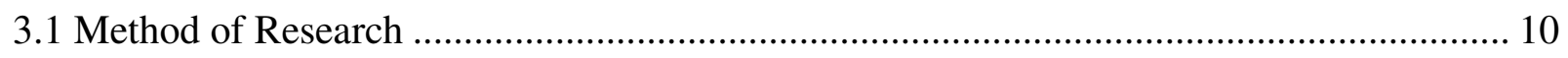

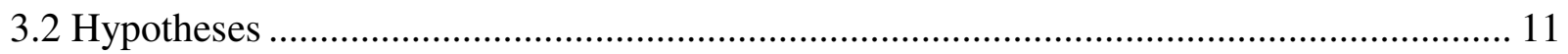

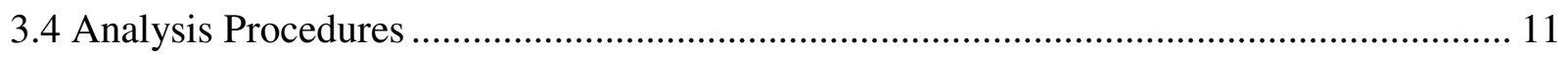

Chapter 4 - Survey Results and Analysis of Data ........................................................... 13

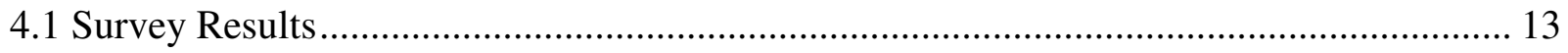

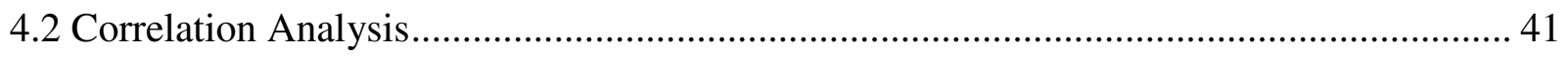

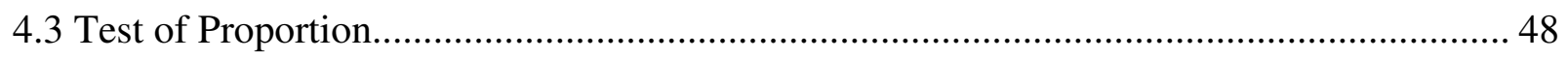

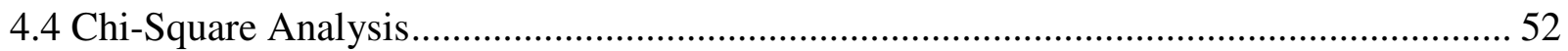

Chapter 5 - Summary of Important Findings .............................................................. 55

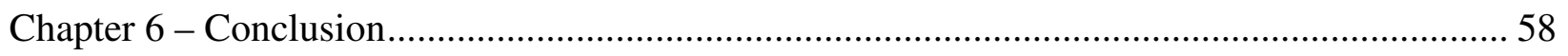

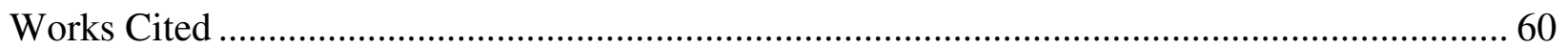

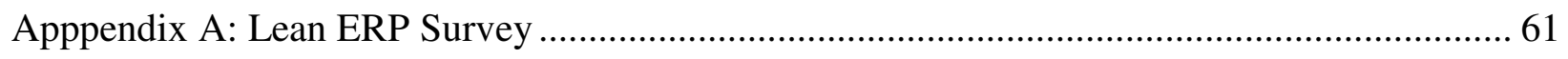




\section{List of Tables}

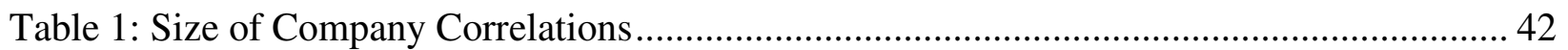

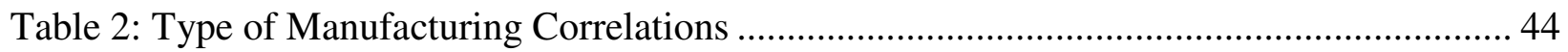

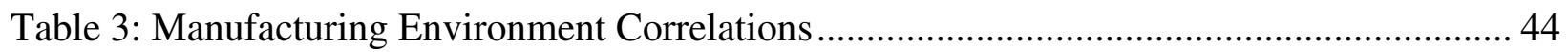

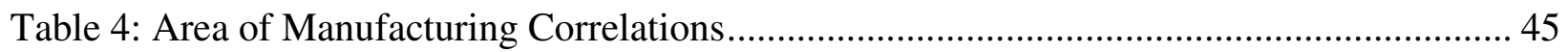

Table 5: Lean ERP Questions (Q27) Correlated to Q1 - Q4 ………………………………..... 47

Table 6: Test of Proportions for 6 out of 8 Survey Responses ................................................... 49

Table 7: Test of Proportions for 7 out of 8 Responses .......................................................... 50

Table 8: Test of Proportions for 8 out of 8 Responses .............................................................. 51 


\section{List of Figures}

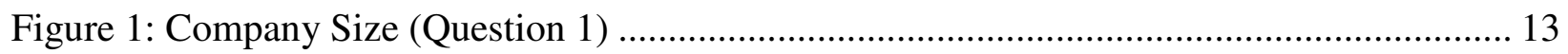

Figure 2: Manufacturing Type (Question 2) ........................................................................ 14

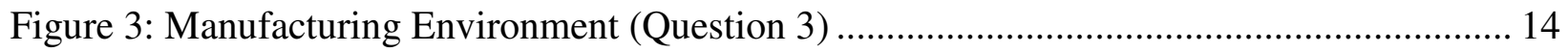

Figure 4: Area of Manufacturing (Question 4) .............................................................. 15

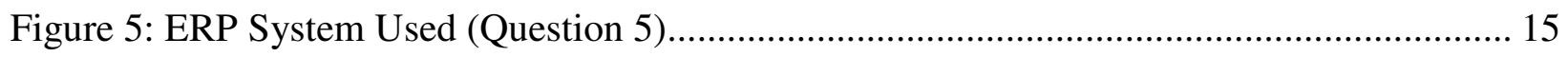

Figure 6: Is Lean Concept Part of Strategic Plan (Question 6)............................................ 16

Figure 7: Percent of Company Practicing Lean (Question 7) ............................................ 16

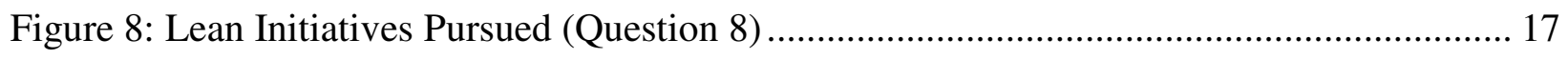

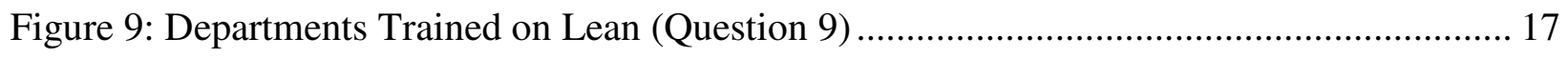

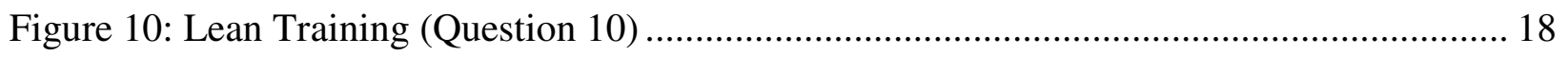

Figure 11: Frequency of Employee Continuing Education on Lean Concepts (Question 11) ..... 18

Figure 12: Did Company Benefit from Lean before ERP Implementation (Question 12).......... 19

Figure 13: Departments Given ERP Training (Question 13)............................................... 19

Figure 14: How ERP Training was Administered (Question 14) ........................................... 20

Figure 15: Frequency of Employee Continuing Education on ERP Concepts (Question 15) ...... 20

Figure 16: Percentage of ERP Integration (Question 16) ............................................... 21 
Figure 17: ERP Implementation Time (Question 17).

Figure 18: Reasons for Module Implementation (Question 18)..... 22

Figure 19: ERP Budget Allotment (Question 19) 22

Figure 20: Percent over Target Budget for ERP Implementation (Question 20) 23

Figure 21: Contribution to Total Cost of Ownership of ERP System (Question 21)...... 23

Figure 22: Levels at Which ERP is Used (Question 22) 24

Figure 23: Departments Using ERP System (Question 23). 24

Figure 24: Use of In-House Tools Instead of ERP (Question 24). 25

Figure 25: ERP Collection of Information (Question 25) 25

Figure 26: ERP Support of Measurements (Question 26) 26

Figure 27: Lean ERP Functionality (Question 27) 27

Figure 28: Use of ERP by Management (Question 28) 28

Figure 29: How Manager-specific Information is Entered (Question 29). 28

Figure 30: How Managers Improve Efficiency 29

Figure 31: Existence of an IT Database 29

Figure 32: IT Problems Handled by ERP System 30

Figure 33: Difficulty of Implementing Additional ERP Modules (Question 33) 30 
Figure 34: ERP Communication Ability with Supply Chain (Question 34)

Figure 35: Supply Chain Elements Monitored by ERP (Question 35) 31

Figure 36: Supply Chain Visibility in ERP (Question 36) 32

Figure 37: Percent of Companies in Supply Chain Interacting with ERP (Question 37)..... 32

Figure 38: How Information is Input into ERP System (Question 38). 33

Figure 39: Percent of Supply Chain Information Being Input Automatically (Question 39)...... 33

Figure 40: Manufacturing Shop Layout (Question 40) 34

Figure 41: Push or Pull Manufacturing (Question 41). 34

Figure 42: Material Flow through Manufacturing Line (Question 42). 35

Figure 43: How Production Information is Collected (Question 43) 35

Figure 44: How Quality Control Collects/Disseminates Information (Question 44) 36

Figure 45: Frequency of Quality Control Report Generation (Question 45). 36

Figure 46: Automatic/Manual Report Generation for QC Department (Question 46)...... 37

Figure 47: Accounting Reports Generation (Question 47) 37

Figure 48: How Accounting Reports Reach Recipients (Question 48)..... 38

Figure 49: Why Accounting Reports Are Not Sent Electronically (Question 49) ....... 38

Figure 50: ERP System Improvement Capability for Accounting (Question 50) 39 
Figure 51: HR Utilization of ERP.

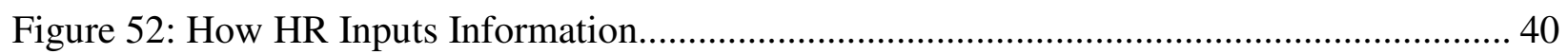

Figure 53: Aspects of HR Being Improved by ERP (Question 53) ........................................... 40

Figure 54: Existence of CRM Module in ERP System (Question 54) ....................................... 41

Figure 55: Does ERP System Respond Automatically to Outside Customers (Question 55) ...... 41

Figure 56: Chi-Square Analysis of Q27 Answer 1 with Question 24......................................... 52

Figure 57: Chi-Square Analysis of Q27 Answer 6 and 7 vs Question 24 .................................. 53

Figure 58: Chi-Square Analysis of Q27, Answer 8 with Question 24........................................ 53

Figure 59: Chi-Square Analysis of Q27, Answer 14 with Question 24.......................................... 54 


\section{Chapter 1 - Introduction}

Lean manufacturing concepts - the elimination of waste through various methods, such as continuous improvement - existed since the early $20^{\text {th }}$ century. Henry Ford implemented some of the earliest lean concepts by incorporating waste reduction, standardization of parts, and design for manufacture into his assembly lines(Ford and Crowther). Since the early 1920s, the concept of lean manufacturing has been developed and refined by several different organizations, most notably by Toyota with the formation of the Toyota Production System (TPS) in the early 1950s. Toyota is credited with being one of the first organizations to develop and utilize lean principles in its manufacturing facilities on a widespread scale. The company's philosophies translated into efficiency and profitability that greatly interested other companies. Consequently, the concept of lean has transformed into a methodology that several companies have emulated.

Enterprise Resource Planning (ERP) systems, however, have been developed and implemented starting in the early 1990s. The advent of the ERP system made it possible to integrate a multitude of formerly manual tasks into a database that would automatically process the information and return valuable results. The incorporation of several, if not all, departments into the ERP system enabled both internal and external customers to share information with one another and with the system itself. However, the extensiveness of implementation and large information sharing also worked against the systems. The enormous scale of a company's system led to huge cost overruns, preventing ERP from being implemented in a time-efficient and costefficient manner. Going over schedule and over budget became a fact of life for many companies. Furthermore, ERP systems' ability to absorb and share such a large volume of information incorporated a large volume of waste that plagued the system's performance. Users requested modules that may not have added any value to their daily operations, further increasing 
the time and cost of ERP implementation. Consequently, ERP systems were not lean from their inception, provided they were implemented in a traditional manner.

ERP systems govern the capture, storage, transfer, and integration of information for the entire enterprise. The thesis investigates whether the concept of lean has shifted from lean manufacturing, such as TPS, to an overall lean enterprise that is governed by an ERP system. In order for lean ERP to be effective, every aspect of a company's functions and activities should be lean, as well as governed by an end to end ERP integration. Certain requirements need to be met in order for a company to be considered a truly lean ERP:

- All recipients of ERP information, both internal and external - management, manufacturing, accounting, quality control, human resources, supply chain, external customers, and other related areas - share a common database, and must be given lean, value-added information.

- A lean ERP system needs to be implemented within the cost and time allotted, and must process only value-added information. Hence, value stream mapping must be applied to any function that interacts with ERP to ensure non-value added information is eliminated.

- The ERP system should offer continuous improvement for the users, the functions of the users, as well as its own future revisions.

- Information that is captured, processed, stored, disseminated, and integrated is done in such a manner that it promotes the lean nature of the organization.

In their current form, both lean and ERP stand alone as two different practices that companies employ in order to be more efficient and profitable. Both practices have their own 
positives and negatives, and companies are finding it tough to incorporate both into their organization at the same time. An attempt is made to define the meaning of the "lean ERP" concept through a literature review of current methods and practices, as well as an analysis of a survey taken by industry professionals. The literature review investigates and identifies problems of implementing both lean and ERP into one organization. The survey, on the other hand, asks questions to various manufacturing organizations to gather insight into how their company is utilizing both lean concepts and their ERP system. The survey tries to answer the question: "Is your whole enterprise really lean?"

The importance of this research should not be underscored by its simplistic nature. Background literary research revealed the lack of discussion of lean applications towards the implementation, organization, and operation of ERP systems. The survey investigates current lean practices of companies and asks pertinent questions on the application of the methods towards companies' ERP systems. Questions asked in the survey progress the definition of "lean ERP" and also enable survey respondents to objectively view their own performance in achieving an ERP system that does not accept any waste, nor generate waste of its own. 


\section{Chapter 2 - Review of Literature}

Several articles were reviewed and studied in order to form a basis for the thesis.

Database searches were performed on "lean ERP" to obtain as much information as possible on the topic. Focus was placed on finding articles that would present the most pertinent information available.

\subsection{The Importance of Lean}

All of the reviewed articles indicate that "manufacturers must adopt lean models or risk extinction" (Caruso) in today's highly-competitive, demand-driven manufacturing world. The implementation of lean manufacturing serves as a starting point for companies to absorb lean into the company culture. Lean thinking and the benefits of its implementation - elimination of waste, continuous improvement, streamlining processes - can only be accepted in other areas of the company after the culture has learned and accepted its benefits. Several sources of information mention significant increases in productivity and reductions in waste due to the implementations of lean principles within their organizations (Executing on lean with production IT; Lean thinking and IT do go together; Tapping into lean processess and systems).

\subsection{The Importance of ERP systems}

Computers are now considered to be mainstream in every modern organization; they offer the ability to process, store, share, and manage an incredible amount of information with unprecedented ease. The relatively inexpensive nature of computer technology in the $21^{\text {st }}$ century has given companies the ability to implement ERP systems into their organizations, as the computing infrastructure is already present. ERP systems are used to incorporate all aspects of a company into one package: the system allows customers, both internal and external, to share 
pertinent information amongst themselves and to have a lot of tasks automated by the system. Charts, graphs, reports can be now automatically performed as opposed to having an employee manually accomplish the task.

\subsection{Implementations of Lean and ERP}

Lean and ERP have one significant commonality - they are expensive to implement. The amount of cost, time, and effort required to implement either one can vary greatly, and usually requires the full backing and resources of a company. Cost variation depends on which paths the company chooses in order to implement their system. Several factors need to be considered:

- The extent of the implementation - will the entire company or just parts of the company have the system implemented?

- The company size and number of physical locations - obviously the larger the company is, and the more locations it has, the more extensive the implementation will need to be.

- The number of modules implemented - Depending on the company's needs, the modules can be few or numerous. The number of modules is also indirectly tied to the company size, as usually a larger company will require a larger assortment of modules to accomplish its daily tasks.

- Whether custom modules or standard modules are ordered - Most ERP software companies (Oracle, SAP, etc) have a set of standard modules offered to every company, but offer customized modules that cater to a particular company's needs

- The amount of training required on using the system - the ERP system is in place, but nobody knows how to use it. Training for the system can be performed either in-house 
(provided that the IT department is trained during the ERP implementation) or can be outsourced as classes held by the ERP implementers.

Regardless of the size of company and extent of implementation, the process of implementing an ERP system wastes time and monetary resources (James-Moore). Cost and scheduling overruns are common to ERP system implementations and are regarded as the norm when such a system is being incorporated into the company. ERP implementation especially is known to be "difficult, wasteful and typically costing five times the purchase price" (JamesMoore). Cost overruns alone can be over 100\% of the allocated funding for the project, indicating that a definite need exists for streamlining or improving the ERP implementation process.

Finding the costs of lean implementation, on the other hand, is a bit more elusive. The figures for costs of lean implementation, the return on that investment, and the productivity increases that are associated with implementing lean are difficult to obtain, as companies do not want the figures to be viewed and misinterpreted by the company's competitors (Costs of Lean implementation). Even so, thorough lean implementation can carry costs of upwards of $\$ 15$ to \$30 million dollars for large organizations, with typical returns on investment being one and a half years (Costs of Lean implementation).

\subsection{Effectiveness of lean and ERP implementations}

Companies who are considering spending large sums of money for either implementing lean or ERP systems (or both) have to realize the value of implementing either one. However, the value of each is often realized separately since most companies change gradually from the customs they have developed over the years. Thus, lean methods and ERP systems are 
implemented at different times in a company's lifetime. Logical thinking would presume that lean methods should be adopted by a company first, and then have an ERP system introduced to an already-lean culture. The already-lean culture would prevent the spawning of poor and variable quality that plagues ERP implementations (Ward). The presumption would be that the company was already actively reducing waste, continuously improving its methods, and religiously following all other lean principles - not only in its manufacturing department, but in all departments of the company. With this assumption, the company would clearly identify all required modules of a potential ERP system and have them implemented in such a way that the modules themselves would not introduce waste into the company. This ideal implementation of ERP would maximize the effectiveness of the system once it is placed into service. Module functions would process and retain information that is specifically of value to the company; all other data would be discarded or not generated in the first place. The system would essentially be a lean ERP system, and all of its capabilities would be guided by lean principles.

However, many barriers exist in forming the ideal lean ERP system. Employees are most likely the largest barrier, and these barriers come in many employee flavors (Ward):

- The "fireman" culture - people who regard themselves as heroes and run around putting out fires. If there are no fires to be put out, they will most likely start one. A Lean ERP system would prevent the majority of fires to be started. The most applicable of this culture is the fire fighting led by top management - deploy impossible plans and then expedite when things go out of schedule.

- People suspicious of simplification - people do not want to figure out a way to simplify matters, as they view that process of simplification as a threat to their job. 
- People who are afraid of risk - The culture would rather increase productivity by $5 \%$ than re-do the entire process, with much greater risk, for a substantial increase in productivity

- Middle management - Resist empowering shopfloor workers with extra tasks and accountability (Ward).

The reviewed articled indicate that only a small percentage of companies are trying to achieve the ideal ERP system. Most companies that have implemented lean and ERP systems have a combination of sorts, where the ERP system is used for sales and purchasing, etc., while their MRP modules are configured for lean pull production (Lean thinking and IT do go together). However, some companies that have implemented lean are now focusing on eliminating waste in areas other than manufacturing, shifting the focus from lean manufacturing to lean thinking (Ward). These companies have seen the value of lean when it was implemented in their manufacturing department, and wish to extend that value to other aspects of the company. They also have a tough road to travel through, as "Software suppliers have not been able to provide the functions required to support lean easily" (Dixon).

\subsection{The Survey and its Relation to Current Literature}

The survey tries to answer the question that has not been posed by any of the reviewed articles: Are companies striving to implement ERP systems that are so methodologically and expertly tailored to the company that they could be considered lean? Current literature lends to the belief that some organizations are certainly trying to come close to that ideal situation. Certain ERP modules, designed by vendors and dubbed "leanware," are surfacing to fill the need of organizations that already have implemented lean and are using it as a major driving force within the company (Ward). The leanware modules promise automation, flexibility, and 
robustness to companies that have lean thinking already in place with its people, machines, and supply chain (Ward). However, the amount of people actually utilizing leanware, as well as the effectiveness of leanware implementations, is currently unknown. The survey asks through several questions if the company uses an ERP system that could be indirectly compared to "leanware." Leanware by definition is constrained to the specific module, while the survey asks if the organization as a whole is lean, and if that lean methodology applies to a company's ERP as well. The respondents' answers will dictate if any practitioners are lean to such a high degree. 


\section{Chapter 3 - Design of Investigation}

\subsection{Method of Research}

A literature review was conducted to see what practices currently existed in the industry. The review was used as a guideline for formulating the survey, which originally consisted of over 100 questions. The large volume of questions encompassed several aspects of both lean and ERP systems. Irrelevant questions were eliminated, others were combined into a single question, and yet others were kept as-is. The resulting 55 questions presented to the industry professionals focused numerous subjects that were pertinent to their company, including questions on lean, ERP, lean ERP, and specific areas of business.

A website was established - $\underline{\text { www.leanerpsurvey.com }}$ - and industry professionals were sent invitation letters to take the survey online. In order to prevent fraudulent submissions, a user name and password were required to gain access to the survey. Each respondent was asked to provide their name, company name, email address, and telephone number in order to further ensure legitimacy of the responses. Once submitted, the survey responses were automatically emailed to the author for analysis. Over 40 personal invitations were sent to industry professionals at various manufacturing organizations. Additionally, a general request for respondents was also posted on several manufacturing-related websites and forums, such as the Society of Manufacturing Engineers' Lean Manufacturing Enterprise Discussions forum. The invitations gave background information on the study, provided a formal request for the recipient to take the survey, and ensured that all company information will be kept strictly confidential. The invitations also indicated that the survey results were solely used as a source of data for analyzing the concept of lean ERP. 
After spending almost a year collecting survey results, only eight companies were able to send a response. The number of respondents had to be limited to eight due to time constraints. However, as the analysis will show, meaningful results were able to be formulated even with such a small sample.

\subsection{Hypotheses}

The following hypotheses were formulated as a result of the literature review:

- Today's ERP systems are not utilized in such a manner as to be considered "lean."

- Companies that utilize lean principles may also employ ERP systems, but the two are used independently with very little, if any, overlap.

The literature review provided some insight on the status of lean and ERP in today's companies. Although many companies claim to have lean ERP, and even more software developers are advertising their ERP systems as being lean, the literature review shed a different light on the concept. Very few articles existed that mentioned the concept of lean ERP - most focused on either lean or ERP. As a result, the hypotheses reflect the idea that although there may be a significant amount of difference between what is advertised and what is actually being practiced in the industry.

\subsection{Analysis Procedures}

An incredible amount of information was obtained from the survey responses. The following statistical methods were utilized to obtain meaningful results:

- Correlation

- Test of Proportions 
- Chi-Square analysis

Correlation and Test of Proportions were primarily used to establish significant conclusions from the survey. Both were used in any way possible that would yield meaningful results. However, the small sample size limited the use of some statistical methods. Chi-Square analysis was limited to specific questions that allowed only one response from each company (as opposed to "Select all that applies" types of questions) and could only be used for questions that had two answer choices. All other questions generated an error when a Chi-Square analysis was attempted. 


\section{Chapter 4 - Survey Results and Analysis of Data}

\subsection{Survey Results}

The following graphs and tables represent the data collected from the lean ERP survey. Each question is labeled appropriately, followed by a short explanation of the responses.

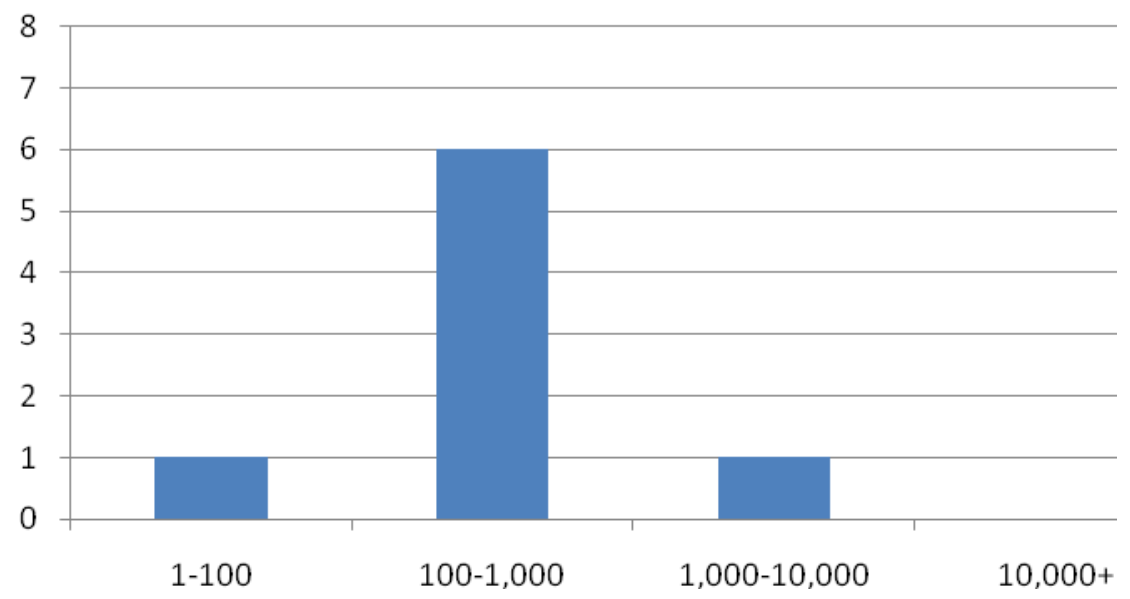

Figure 1: Company Size (Question 1)

Survey results for question 1 illustrate the sizes of companies that responded to the survey. The majority of companies had between 100-1,000 employees, as evident by the six out of eight responses in that category. 


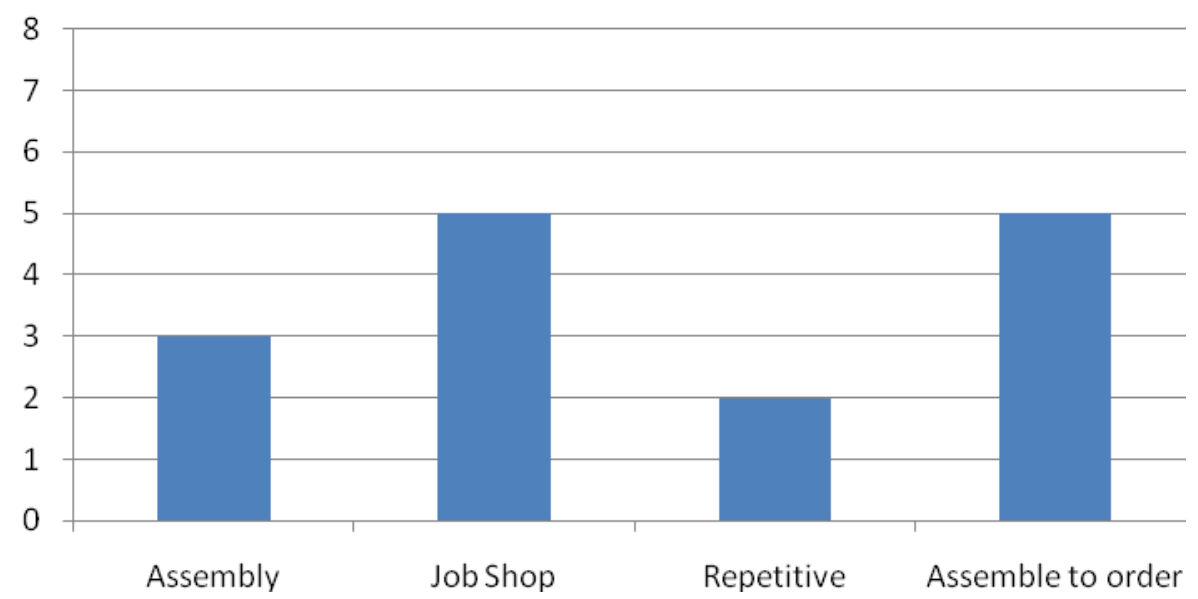

Figure 2: Manufacturing Type (Question 2)

Survey results for question 2 illustrate manufacturing capabilities of the companies that responded to the survey. Types of manufacturing were more spread out than company sizes. Multiple responses were given in some categories, indicating that the respondents implement more than one type of manufacturing within their organizations.

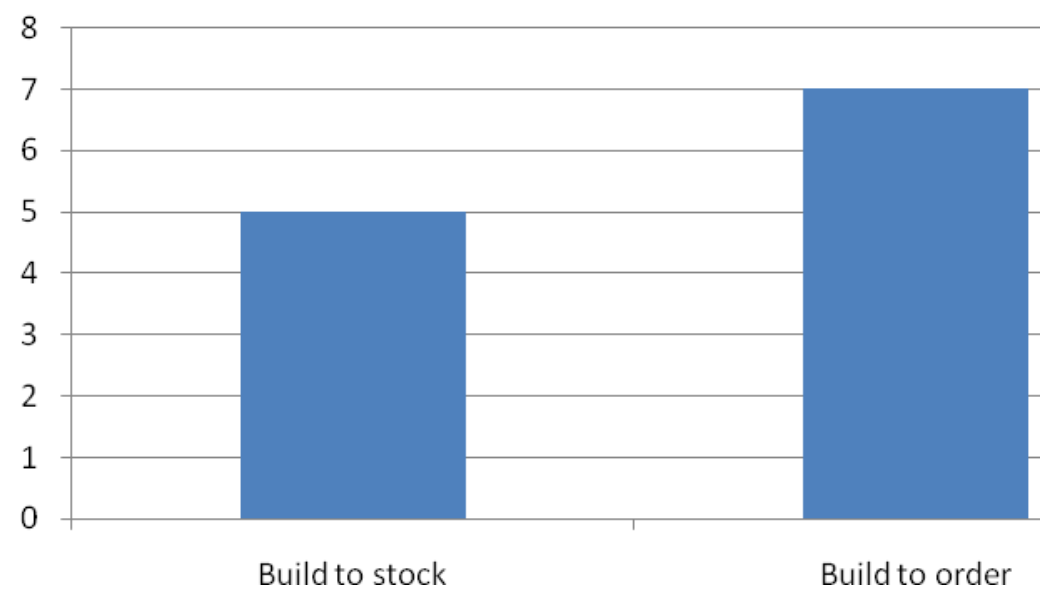

Figure 3: Manufacturing Environment (Question 3)

Survey results for question 3 illustrate the type of manufacturing environment of the respondents. More than eight responses indicate that some companies have both build to stock and build to order environments. 


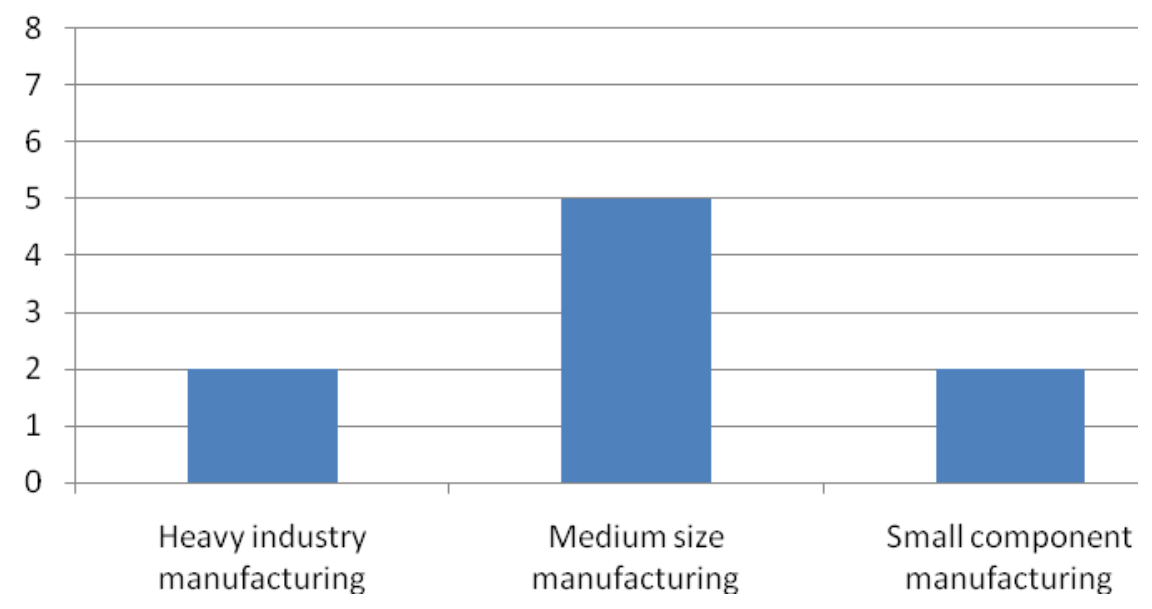

Figure 4: Area of Manufacturing (Question 4)

Survey results for question 4 illustrate the areas of manufacturing being utilized by the respondents. A lone company performed services in two different areas - all others were focused on a specific industry.

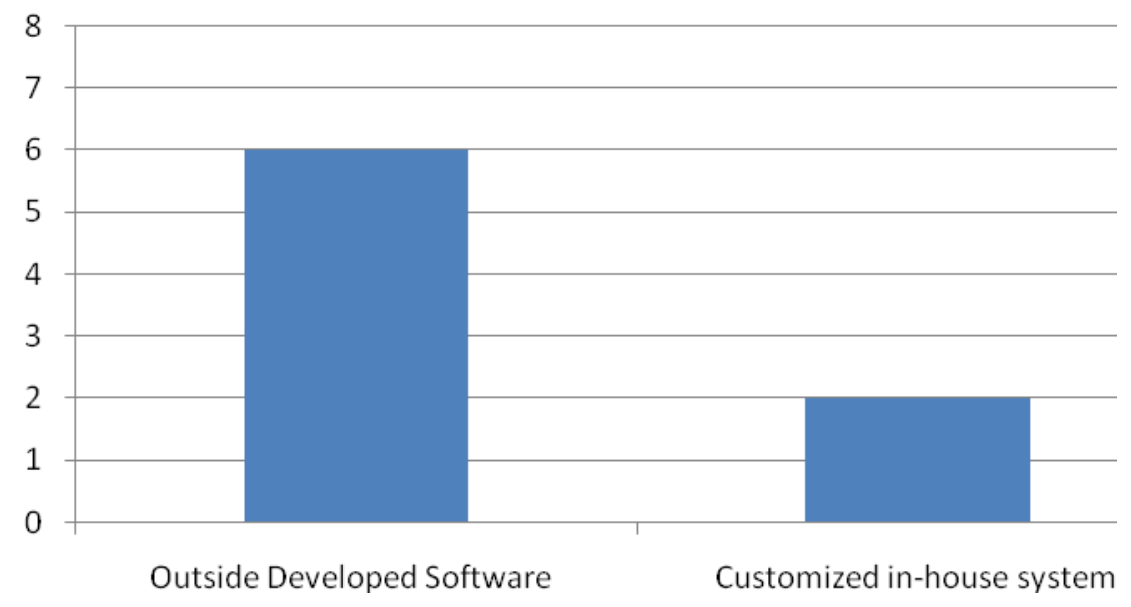

Figure 5: ERP System Used (Question 5)

Survey results for question 5 indicate that the majority of the ERP systems used by the respondents were packages developed outside of the company. 


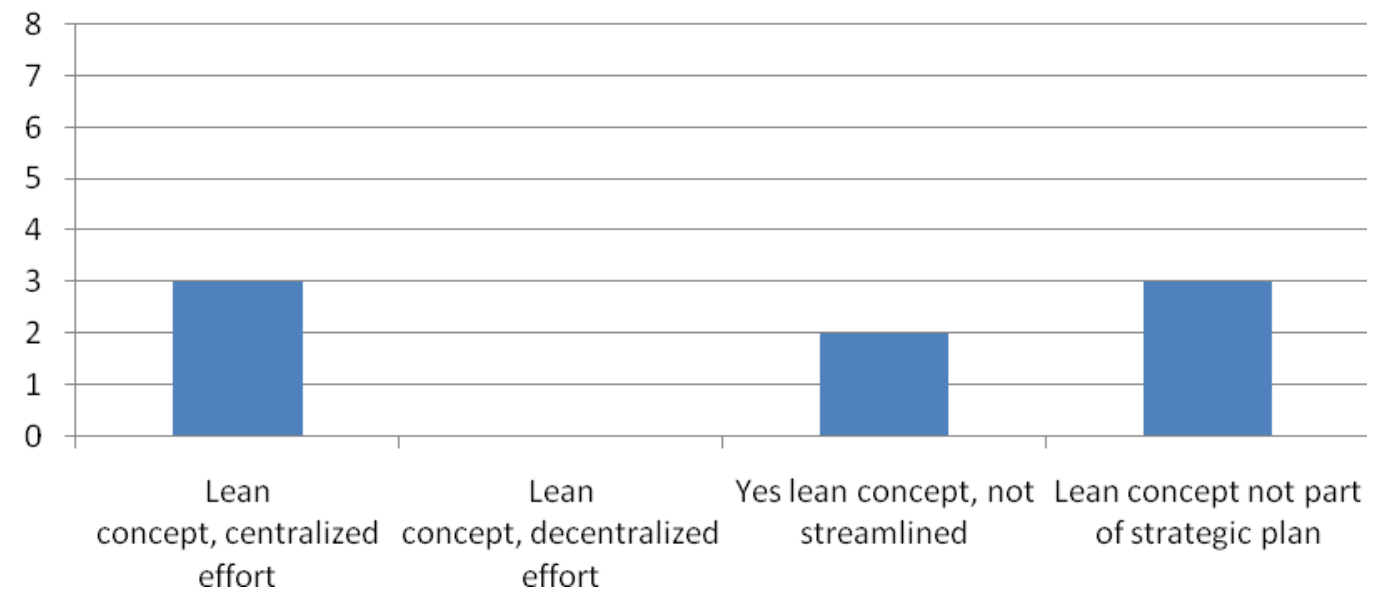

Figure 6: Is Lean Concept Part of Strategic Plan (Question 6)

Survey results for question 6 indicate that the majority of respondents included the lean concept in their strategic plans, but only some of the respondents indicate that the concept has been streamlined through a centralized effort. Others did not streamline or did not include the lean concept as part of their strategic plan.

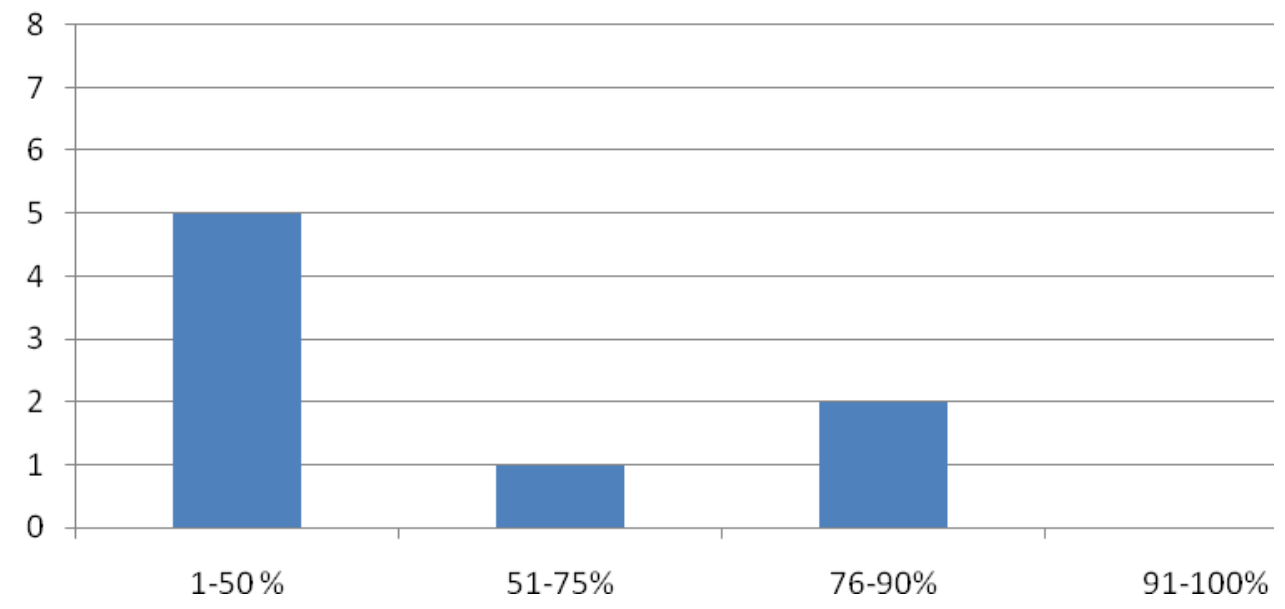

Figure 7: Percent of Company Practicing Lean (Question 7)

Survey results for question 7 show the extent of each company's lean practices. The majority of respondents had only $50 \%$ or less of the company practicing lean concepts, indicating that several departments may not be operating as effectively as possible. 


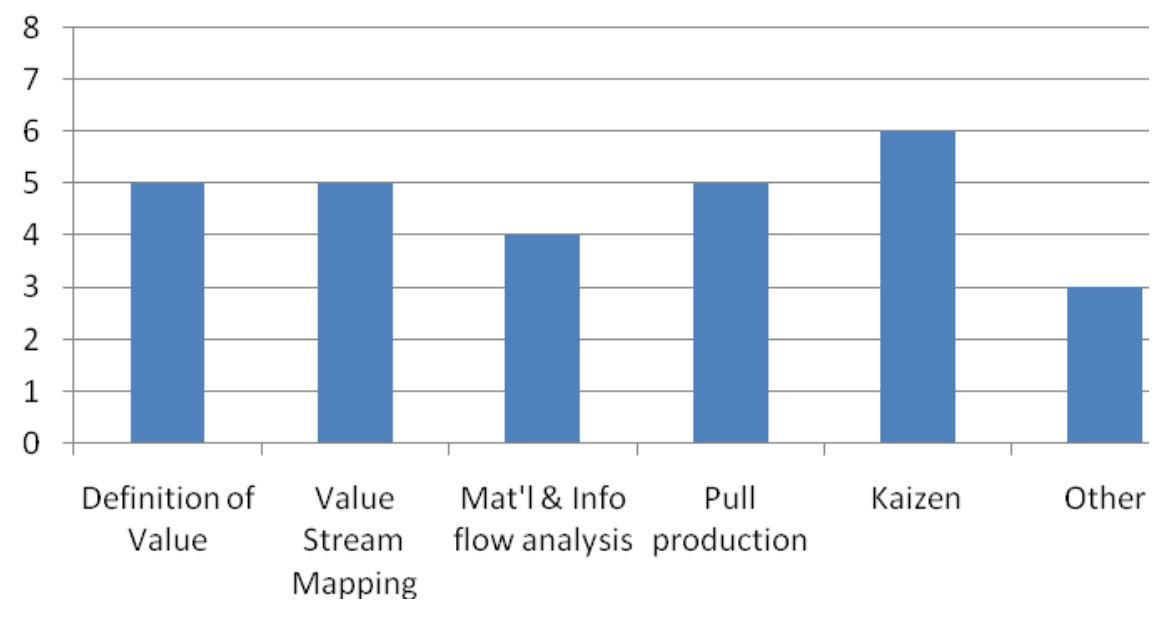

Figure 8: Lean Initiatives Pursued (Question 8)

Survey results for question 8 indicate that several different lean initiatives are being pursued at companies which practice lean.

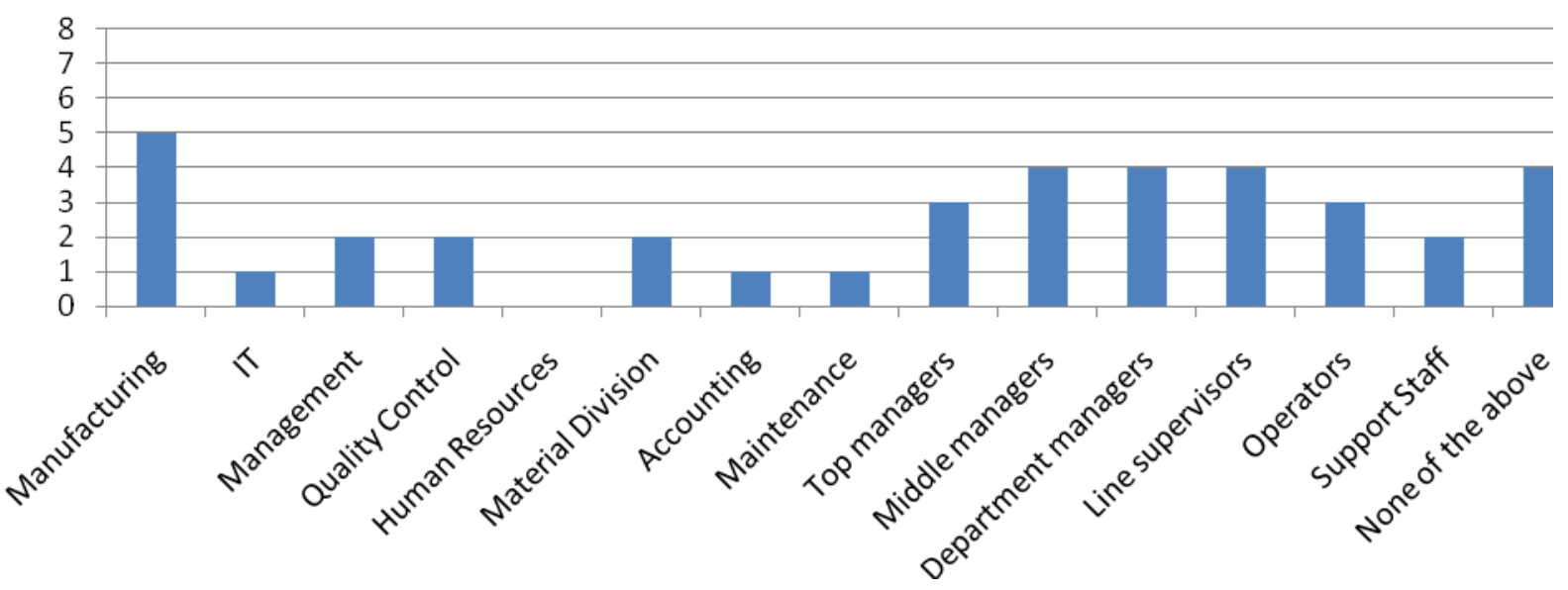

Figure 9: Departments Trained on Lean (Question 9)

Survey results for question 9 indicate that various departments have been trained on lean. The majority of responses show that manufacturing departments, middle and department managers, and line supervisors receive the most lean training, whereas human resources, IT, accounting, and maintenance receive the least. 


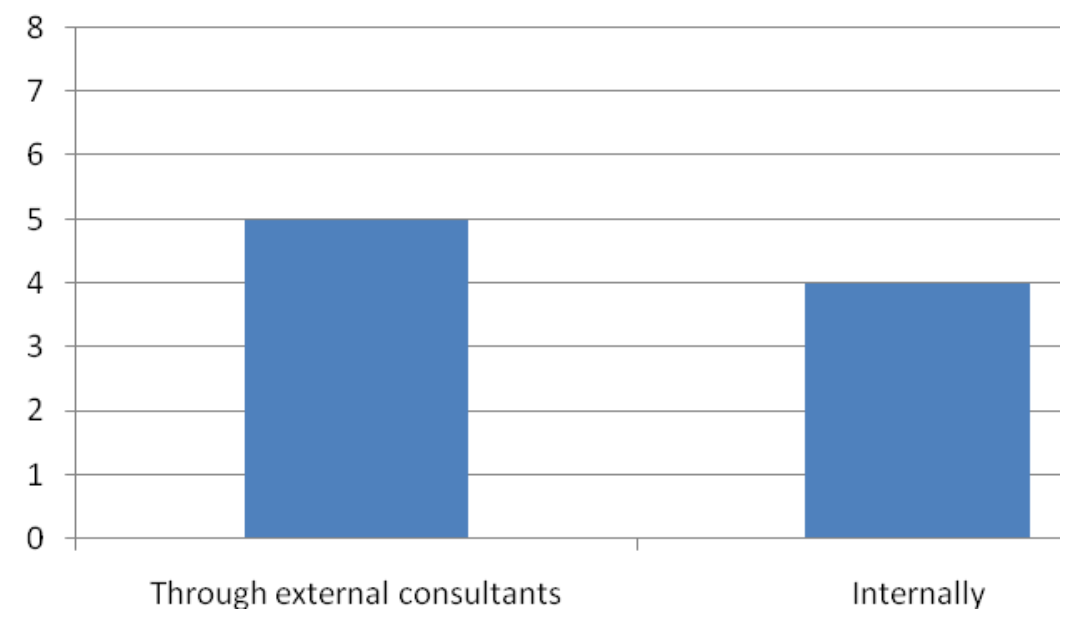

Figure 10: Lean Training (Question 10)

Survey results for question 10 shows that lean training was almost equally divided between external consultants and internal training, with companies utilizing both methods to train employees.

\begin{tabular}{|c|c|c|c|c|c|}
\hline Employees: & Every month & Every 3 months & Every 6 months & Every year & Never \\
\hline Top managers & 0 & 0 & 1 & 3 & 4 \\
\hline Middle managers & 0 & 0 & 2 & 3 & 3 \\
\hline Department managers & 0 & 2 & 0 & 3 & 3 \\
\hline Line supervisors & 0 & 2 & 2 & 2 & 3 \\
\hline Operators & 0 & 1 & 3 & 2 & 3 \\
\hline Support staff & 1 & 0 & 1 & 4 & 3 \\
\hline
\end{tabular}

Figure 11: Frequency of Employee Continuing Education on Lean Concepts (Question 11)

Survey results for question 11 indicate that the majority of companies do not offer employee continuing education on lean concepts. 


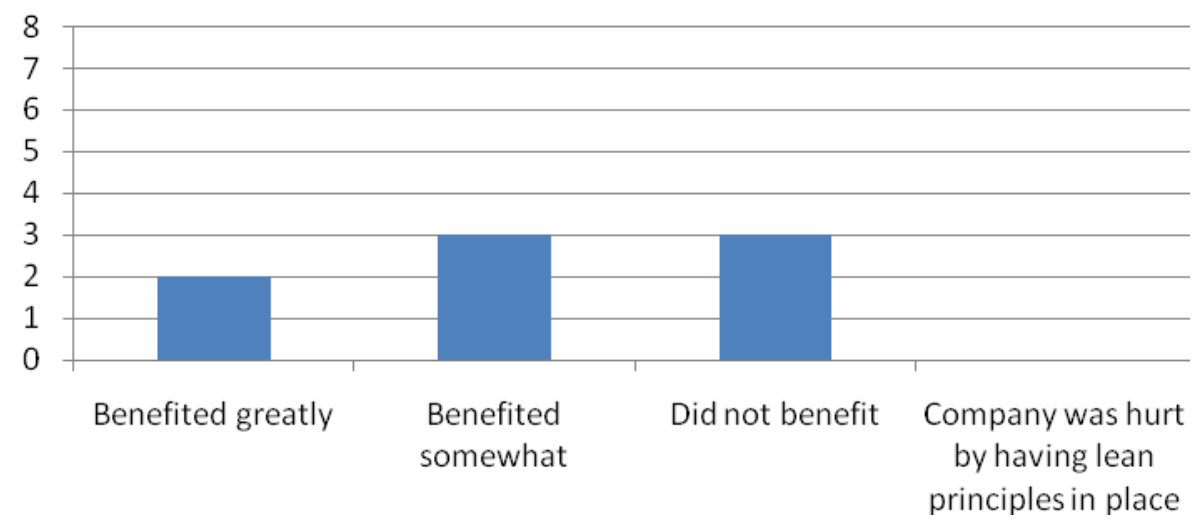

Figure 12: Did Company Benefit from Lean before ERP Implementation (Question 12)

Survey results for question 12 show that the almost two-thirds of companies benefitted from already practicing lean before implementing their ERP system. No companies were disadvantaged from having lean in place before the implementation.

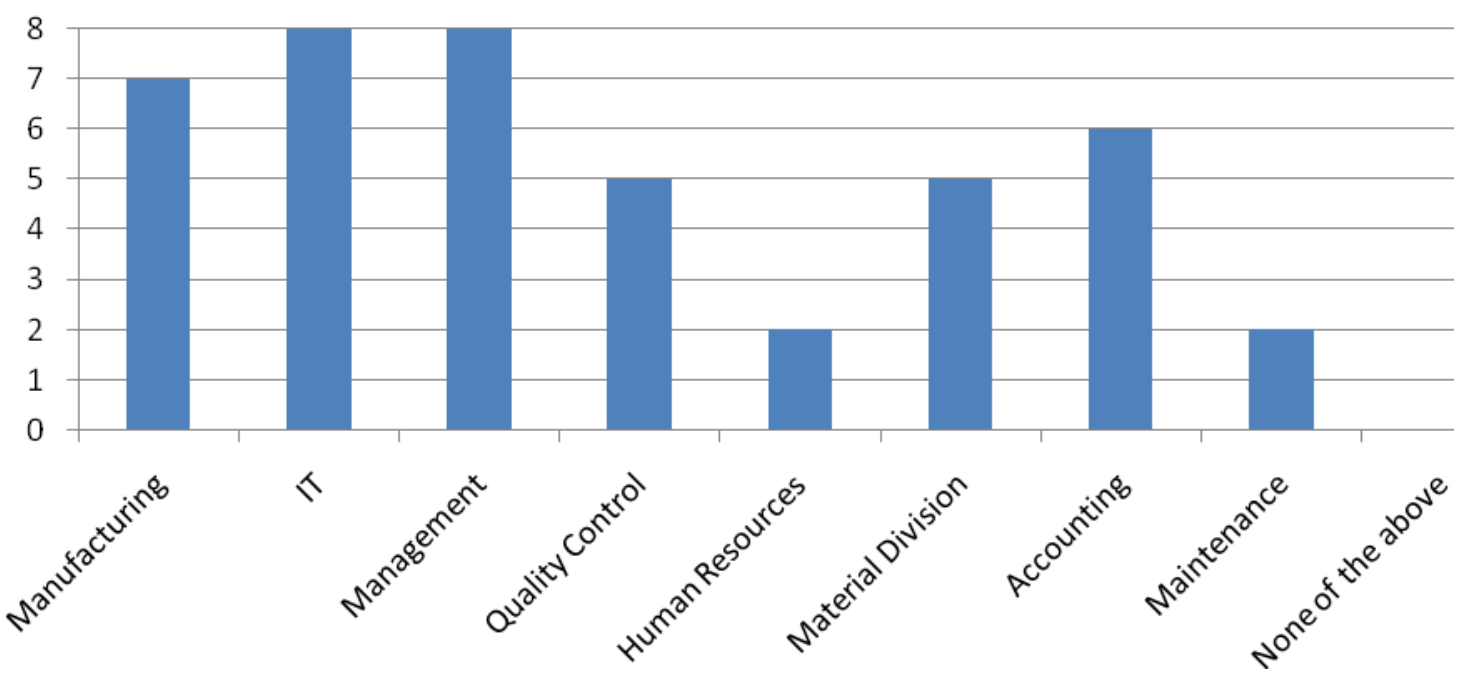

Figure 13: Departments Given ERP Training (Question 13)

Survey results for question 13 indicate a much larger response for employee ERP training, as opposed to lean training. All respondents trained their IT and management staff, and seven of eight trained the manufacturing department. However, only two of eight trained their HR and maintenance personnel. 


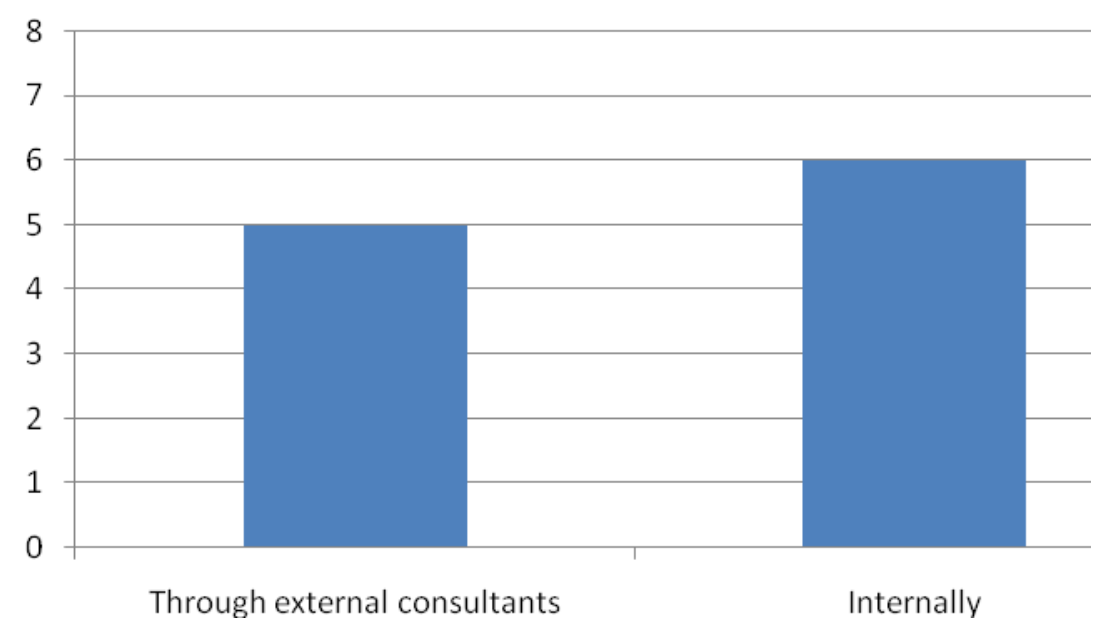

Figure 14: How ERP Training was Administered (Question 14)

Survey results for question 14 show that ERP training was administered through a combination of external consulting and internal personnel.

\begin{tabular}{|c|c|c|c|c|c|}
\hline Employees: & Every month & Every 3 months & Every 6 months & Every year & Never \\
\hline Top managers & 0 & 0 & 0 & 2 & 6 \\
\hline Middle managers & 0 & 0 & 1 & 1 & 6 \\
\hline Department managers & 0 & 0 & 1 & 1 & 6 \\
\hline Line supervisors & 0 & 1 & 0 & 1 & 6 \\
\hline Operators & 0 & 1 & 0 & 1 & 6 \\
\hline Support staff & 1 & 0 & 0 & 1 & 6 \\
\hline
\end{tabular}

Figure 15: Frequency of Employee Continuing Education on ERP Concepts (Question 15)

Survey results for question 15 indicate that the majority of respondents - six out of eight - do not offer continuing education on the usage of ERP. 


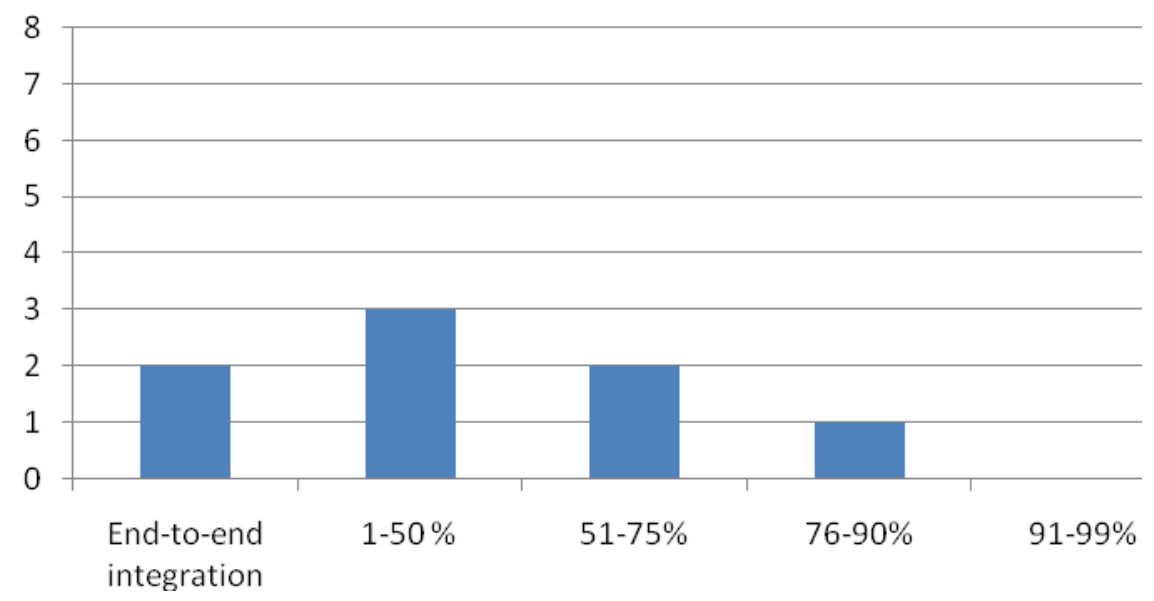

Figure 16: Percentage of ERP Integration (Question 16)

Survey results for question 16 shows that the majority of companies implemented only a partial ERP system, as opposed to an end-to-end integration.

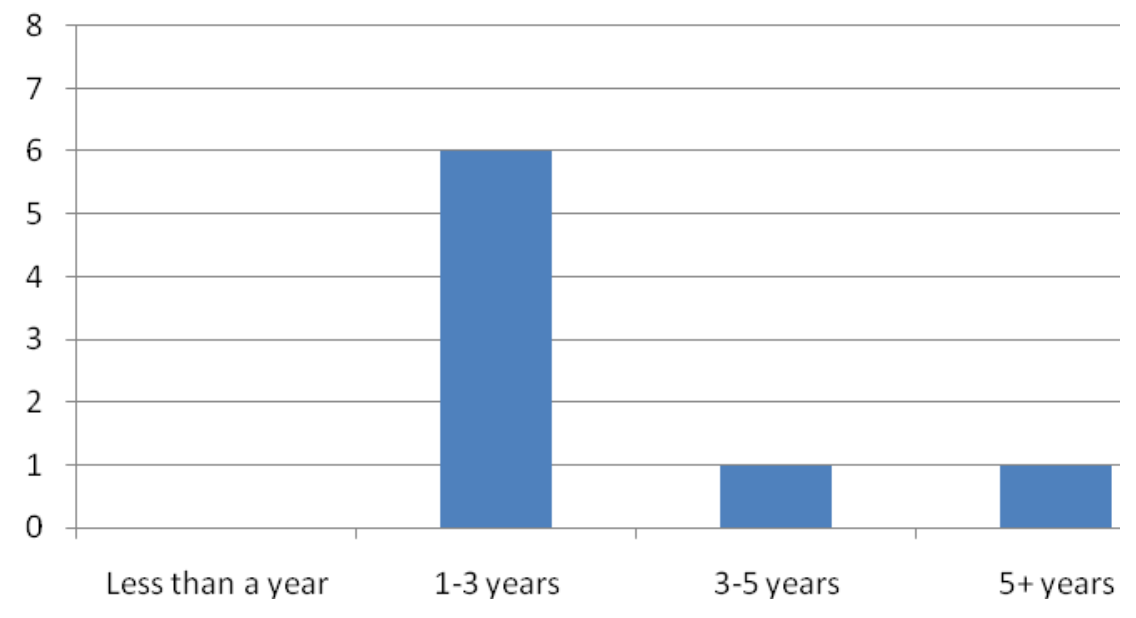

Figure 17: ERP Implementation Time (Question 17)

Survey results for question 17 indicate that the majority of ERP installations took between one and three years to fully implement. 


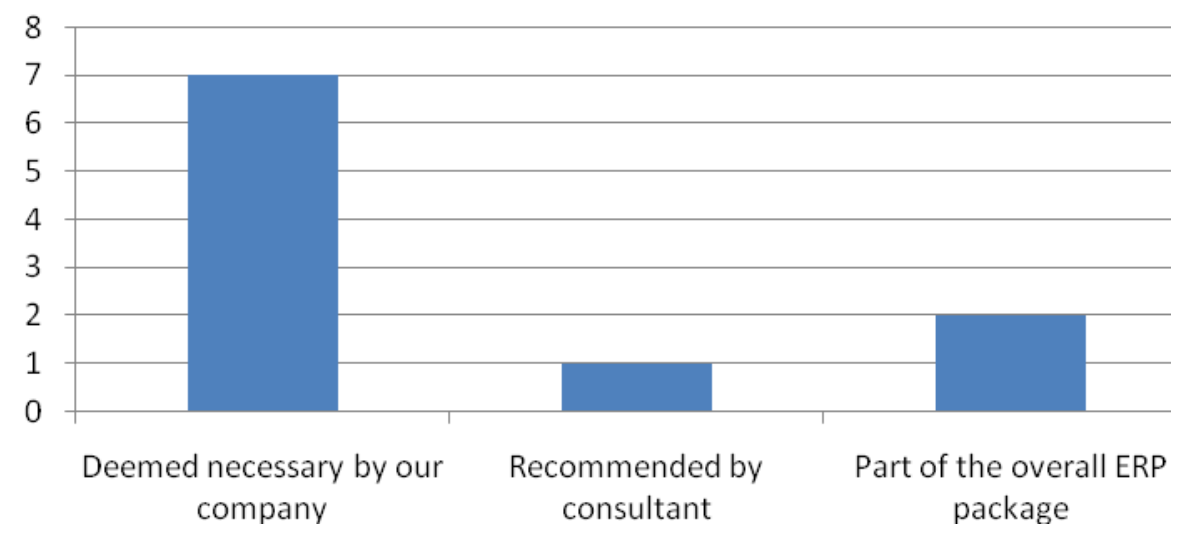

Figure 18: Reasons for Module Implementation (Question 18)

Survey results for question 8 indicate that several different lean initiatives are being pursued at companies which practice lean.

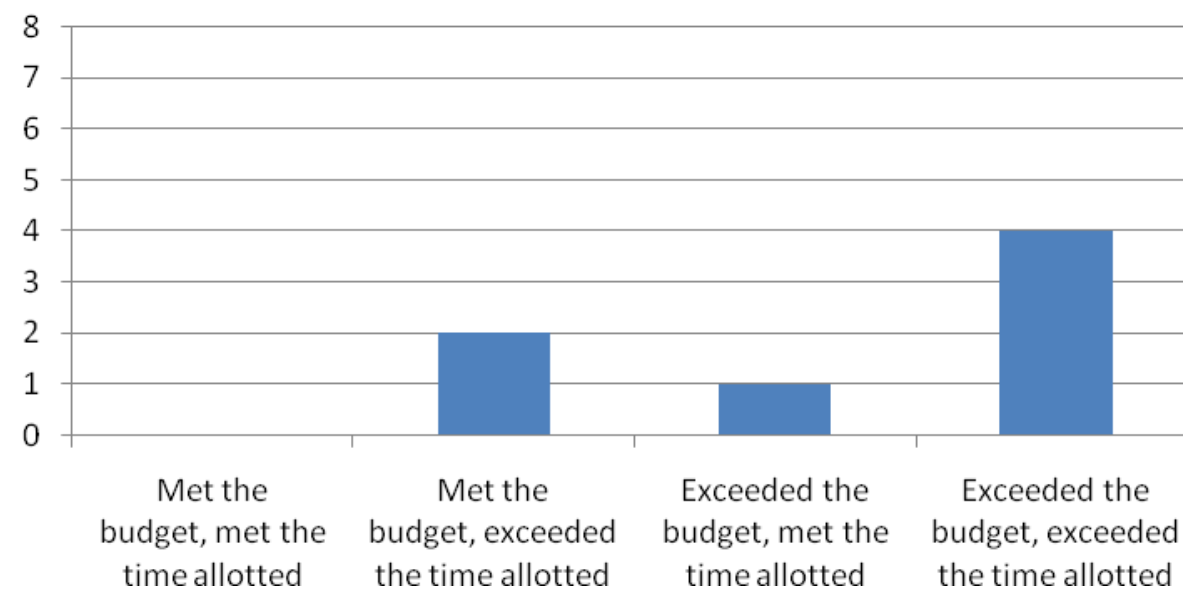

Figure 19: ERP Budget Allotment (Question 19)

Survey results for question 19 show that no companies met the budget and time allotted when implementing their ERP systems. Half exceeded both, and three exceeded one of the two factors. 


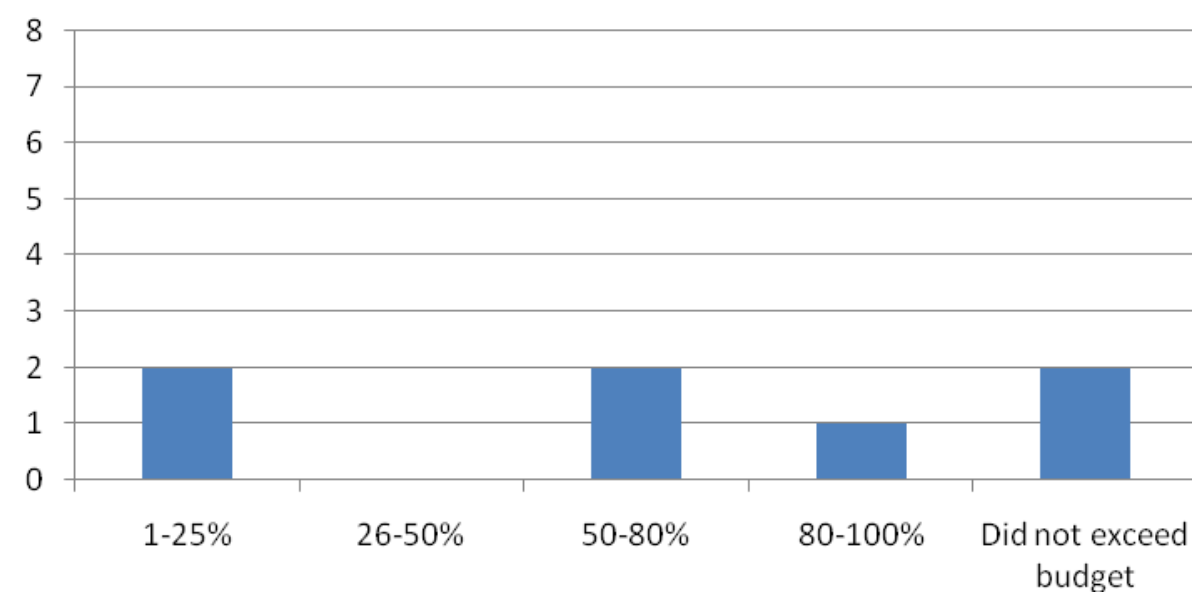

Figure 20: Percent over Target Budget for ERP Implementation (Question 20)

Survey results for question 20 display a wide range of percentages which the ERP

implementation went over budget. Three of eight respondents indicated that the target budget was exceeded by $50 \%$ or more.

\begin{tabular}{|c|c|c|c|c|c|}
\cline { 2 - 6 } \multicolumn{1}{c|}{} & \multicolumn{5}{c|}{ Cost Scale (1 lowest, 5 highest) } \\
\hline Factor & One & Two & Three & Four & Five \\
\hline $\begin{array}{c}\text { Multiple installation } \\
\text { sites }\end{array}$ & 1 & 4 & 0 & 1 & 1 \\
\hline $\begin{array}{c}\text { Extensive hardware } \\
\text { upgrades }\end{array}$ & 1 & 3 & 0 & 2 & 1 \\
\hline $\begin{array}{c}\text { Extensive non-ERP } \\
\text { software upgrades }\end{array}$ & 1 & 1 & 0 & 4 & 1 \\
\hline $\begin{array}{c}\text { Extensive training for } \\
\text { entire company }\end{array}$ & 1 & 1 & 3 & 1 & 1 \\
\hline $\begin{array}{c}\text { Cost of ERP software } \\
\text { modules }\end{array}$ & 0 & 1 & 2 & 2 & 2 \\
\hline
\end{tabular}

Figure 21: Contribution to Total Cost of Ownership of ERP System (Question 21)

Survey results for question 21 indicate a widespread range of factors contributing to the overall cost of ownership for ERP systems. Half of the respondents cited "Extensive non-ERP software upgrades" as a four out of five cost, signifying that the category may be a source of cost overruns for ERP implementations. 


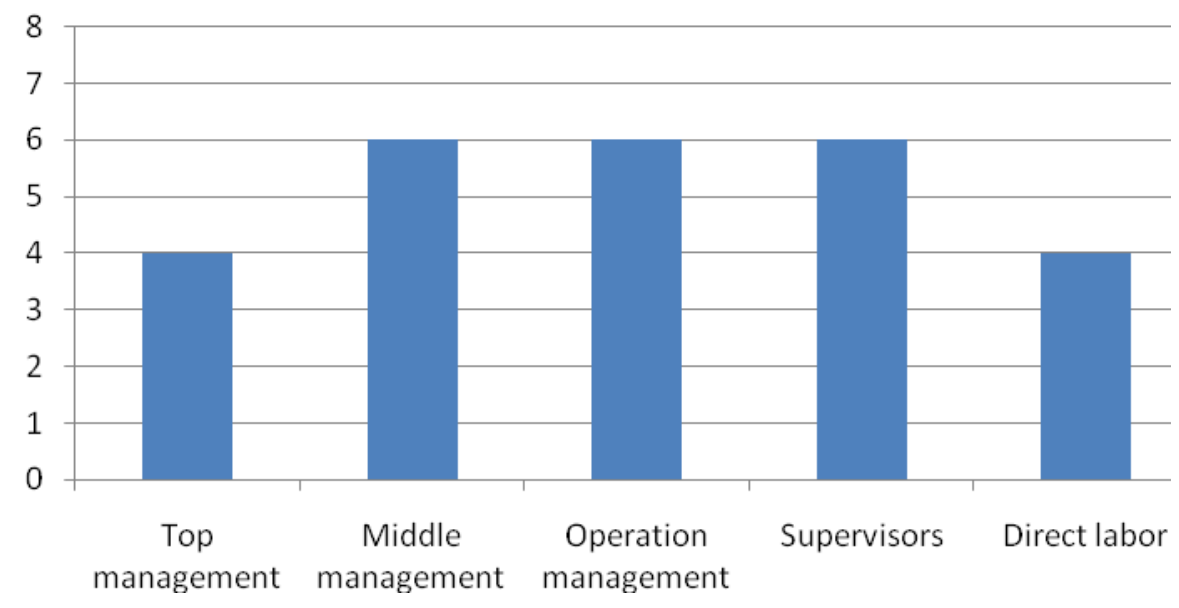

Figure 22: Levels at Which ERP is Used (Question 22)

Survey results for question 22 show that ERP is uniformly used at various levels of the company.

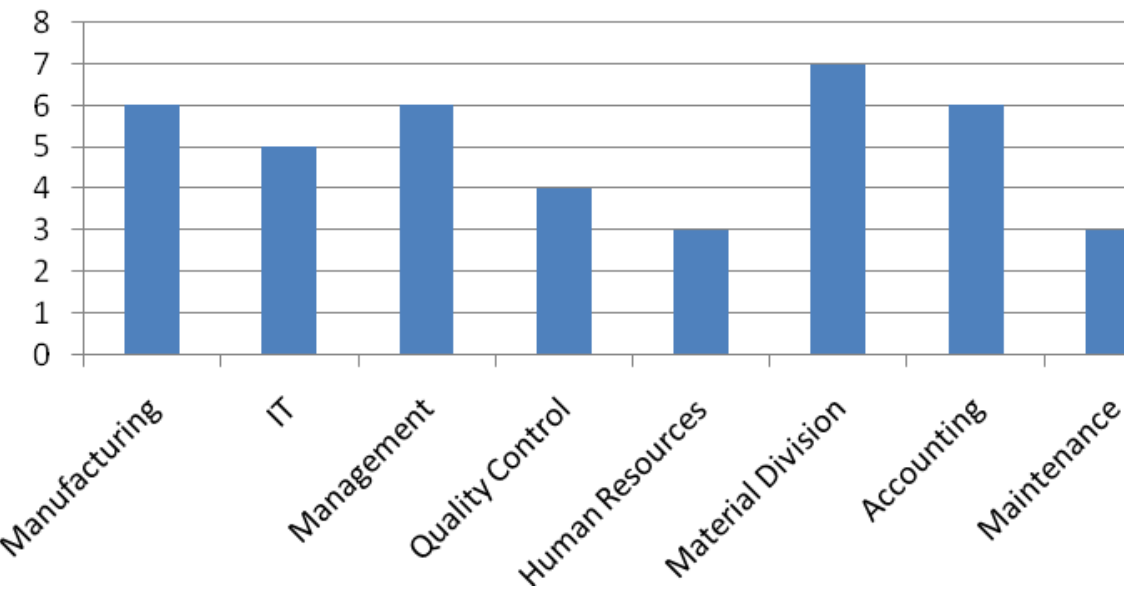

Figure 23: Departments Using ERP System (Question 23)

Survey results for question 23 show that ERP is somewhat uniformly used at different departments within the company. 


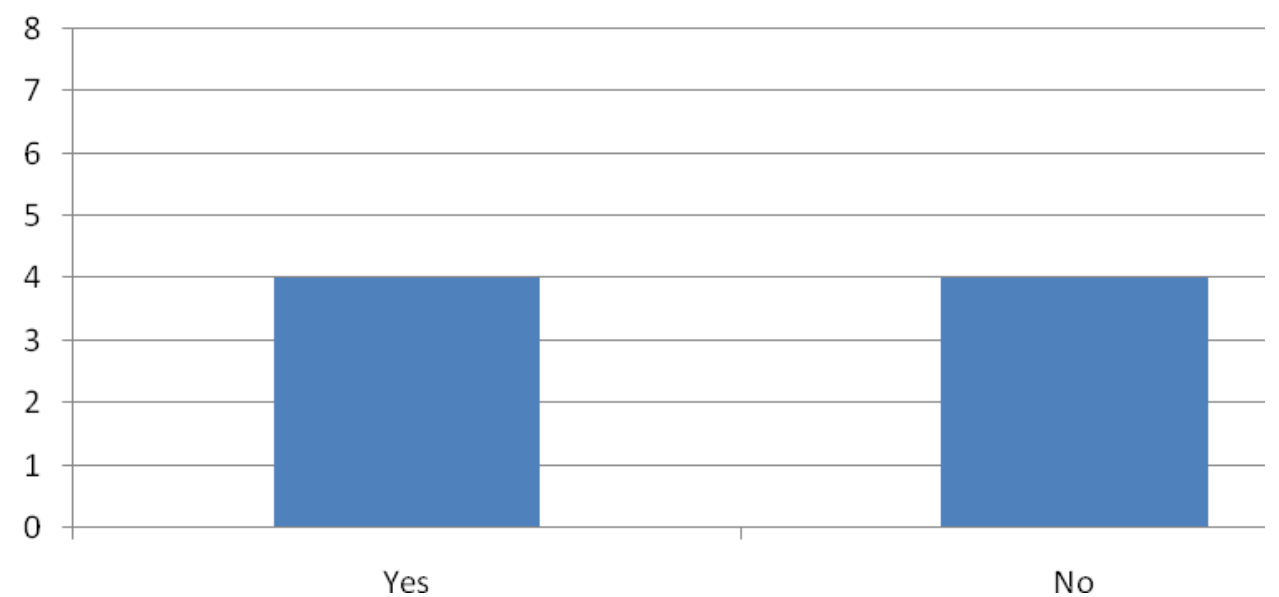

Figure 24: Use of In-House Tools Instead of ERP (Question 24)

Survey results for question 24 indicate that $50 \%$ of the respondents have in-house tools that are used in order to avoid using the ERP system.

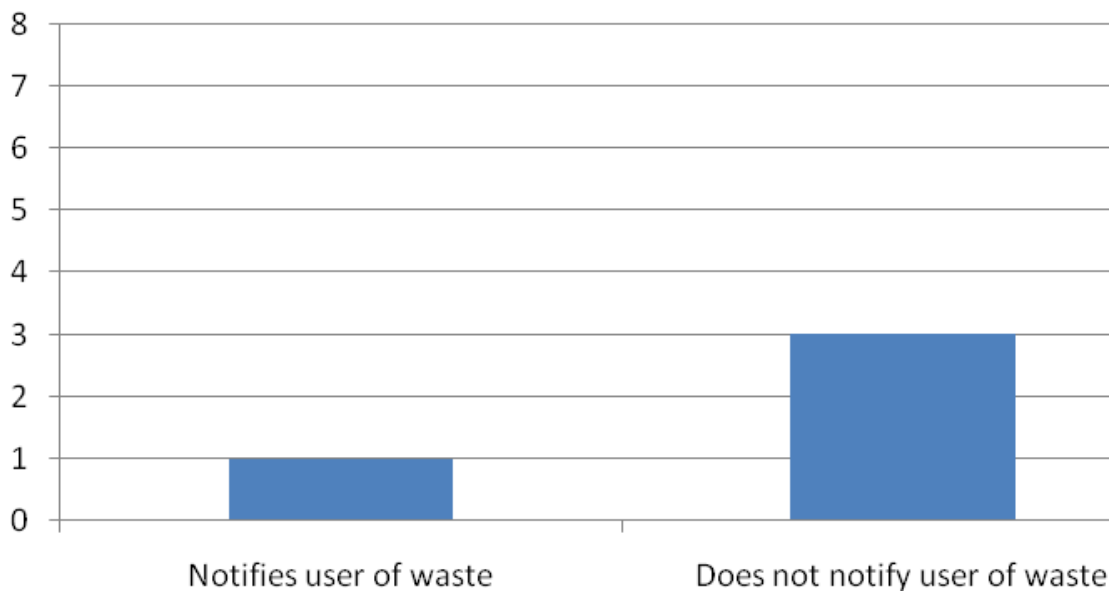

Figure 25: ERP Collection of Information (Question 25)

Survey results for question 25 show that only one respondent's ERP system is able to detect waste entering the system. 


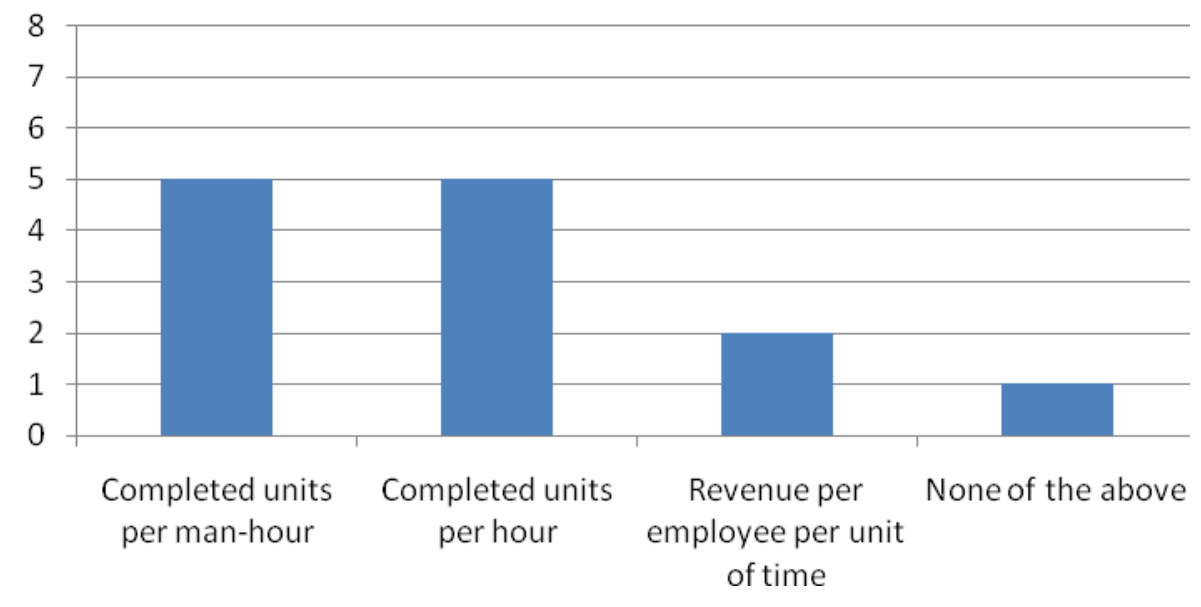

Figure 26: ERP Support of Measurements (Question 26)

Survey results for question 26 shows that the majority of measurements are being supported at cell, operations, and corporate levels. Only one respondent did not have any of the measurements supported. 


\begin{tabular}{|l|c|}
\hline \multicolumn{1}{|c|}{ Lean ERP Functionality } & $\begin{array}{c}\text { \# of "Yes" } \\
\text { Responses }\end{array}$ \\
\hline Provides for continuous measurement and reporting of setup times & 3 \\
\hline Enables comparisons of actual setup time vs. planned setup time & 3 \\
\hline Includes data and spreadsheets for line balancing and capacity analysis & 3 \\
\hline Provides for continuous lot size analysis & 1 \\
\hline Compares actual lot size to planned lot size & 1 \\
\hline Notifies the supply chain when a visual determination reorder point is reached & 5 \\
\hline Supports electronic transfer of replenishment signals & 5 \\
\hline Supports electronic printing and posting of kanban signals & 5 \\
\hline Supports automatic capture of line/cell production completion times & 3 \\
\hline Offers real-time measurement of performance to takt time & 0 \\
\hline $\begin{array}{l}\text { Includes spreadsheets for calculating line/load balance and total labor } \\
\text { requirements }\end{array}$ & 3 \\
\hline $\begin{array}{l}\text { Utilizes labor measurement as an indicator of performance for effective line/load } \\
\text { balancing }\end{array}$ & 0 \\
\hline $\begin{array}{l}\text { Performs real-time tracking of wait, transportation, and queue times on the road } \\
\text { and in the warehouse }\end{array}$ & 0 \\
\hline Supports electronic work instructions with color coding, digital photos, or video & 2 \\
\hline Supports electronic, color-coded work instructions & 2 \\
\hline Supports embedded checks that prevent careless errors to be made & 1 \\
\hline Supports measurement of safety stock by line or cell & 2 \\
\hline Tracks actual inventory turnover vs. planned inventory turnover & 3 \\
\hline Integrates quality measurements into comprehensive performance measurements & 1 \\
\hline Supports effective, custom measurement of the cost of quality & 1 \\
\hline Supports a direct measurement of lead time reductions & 1 \\
\hline Compares actual lead time vs. planned lead time & 3 \\
\hline
\end{tabular}

Figure 27: Lean ERP Functionality (Question 27)

Survey results for question 27 indicate that the majority of respondents do not have lean ERP functionality built into their ERP systems. Only three categories (of twenty-two) have a majority of respondents indicating that their system supports the specified functionality. 


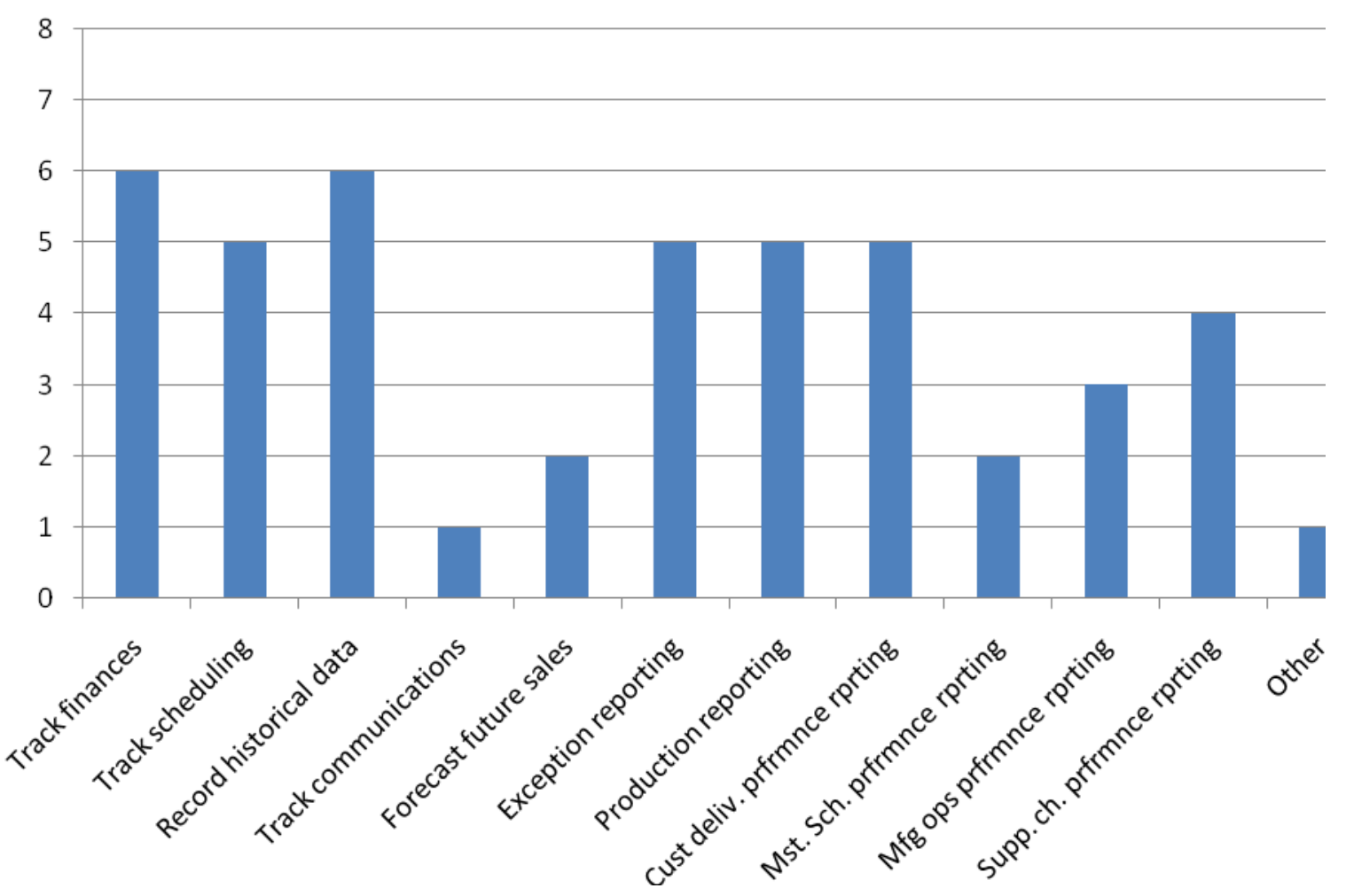

Figure 28: Use of ERP by Management (Question 28)

Survey results for question 28 showcases the usage of ERP by the management.

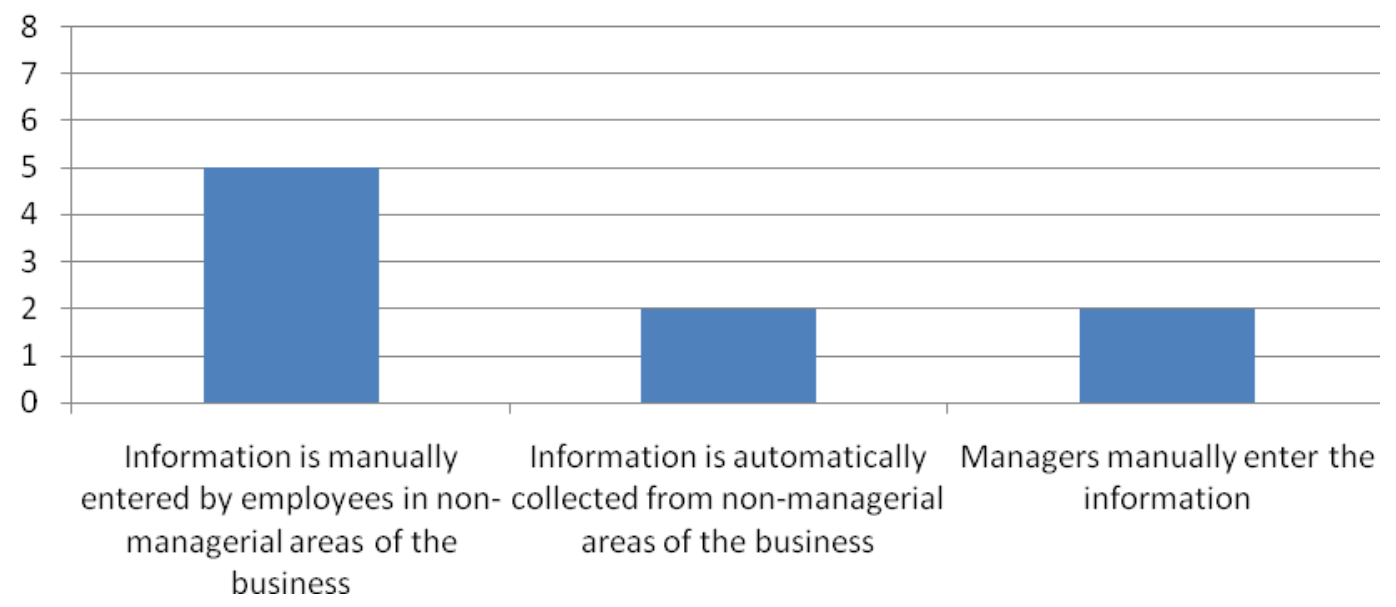

Figure 29: How Manager-specific Information is Entered (Question 29)

Survey results for question 29 indicates that manager-specific information is largely entered through manual means, either by the managers themselves or by other employees. 


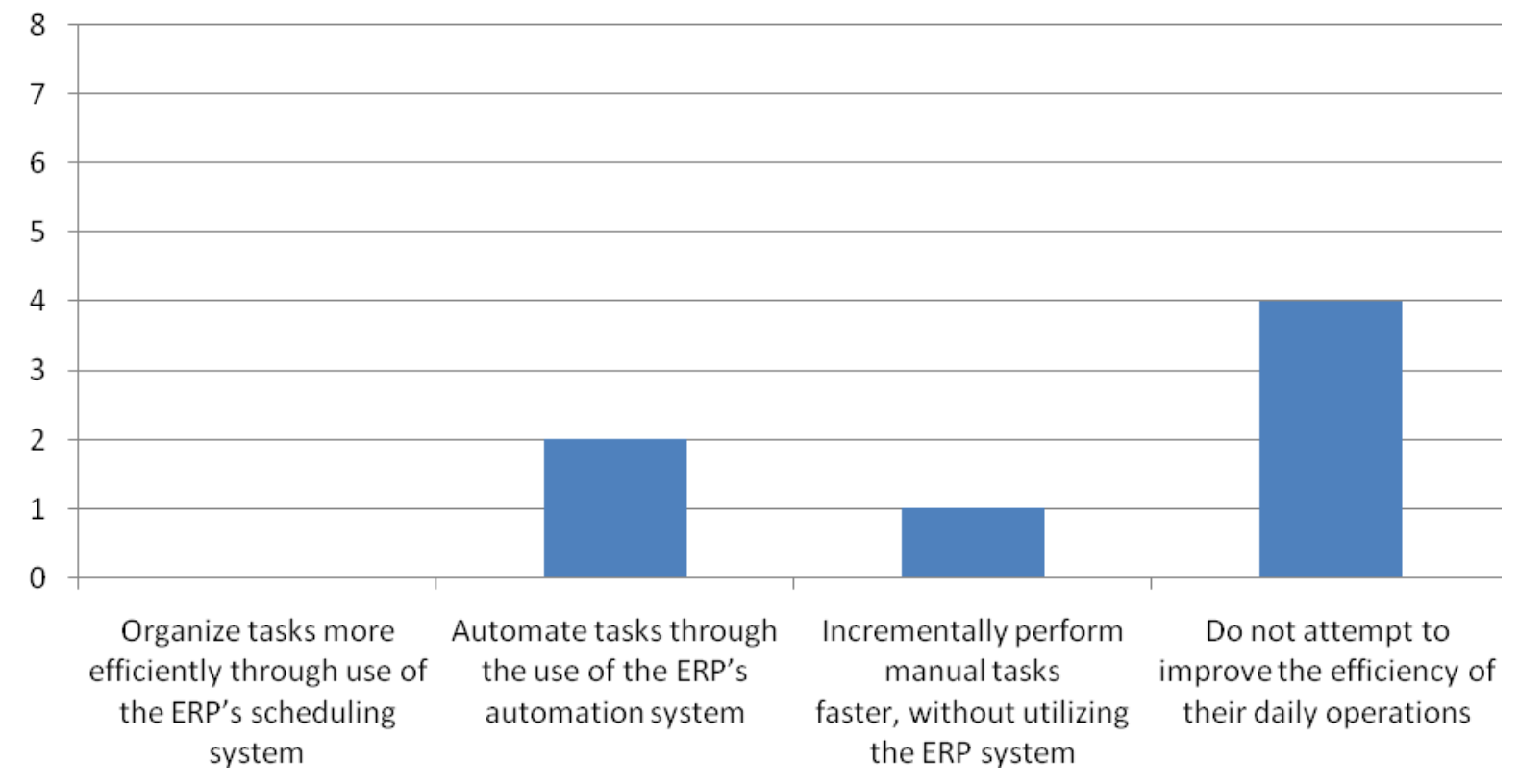

Figure 30: How Managers Improve Efficiency

Survey results for question 30 show that more than half of respondent's managers do not attempt to improve efficiency of their daily operations in any manner.

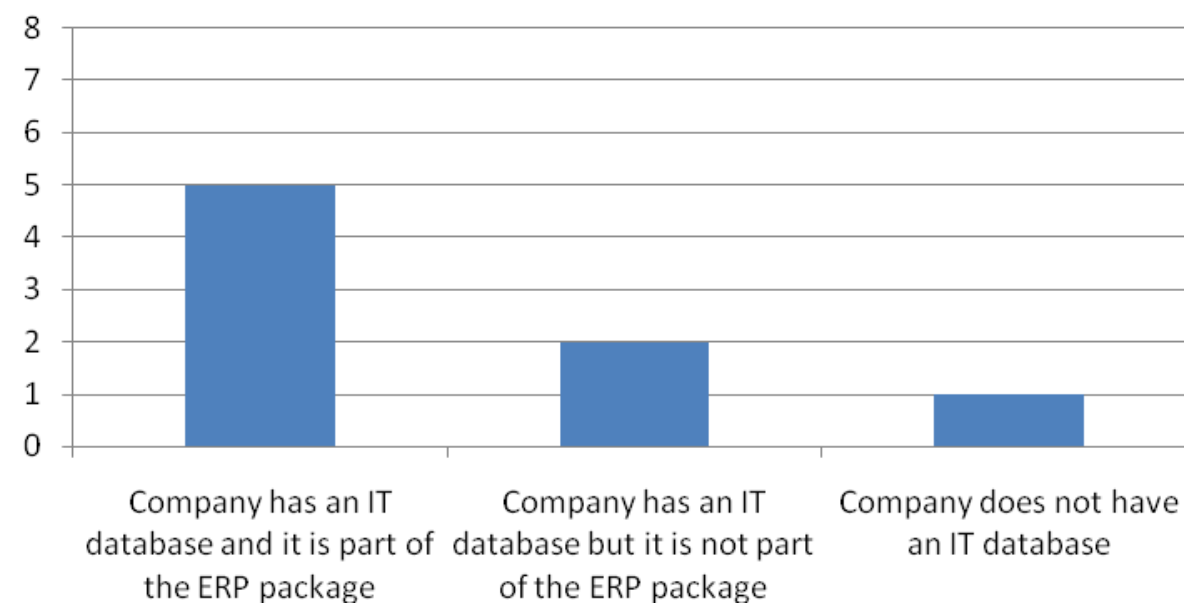

Figure 31: Existence of an IT Database

Survey results for question 31 show that the majority of IT departments have an IT database that is integrated into the ERP system. 


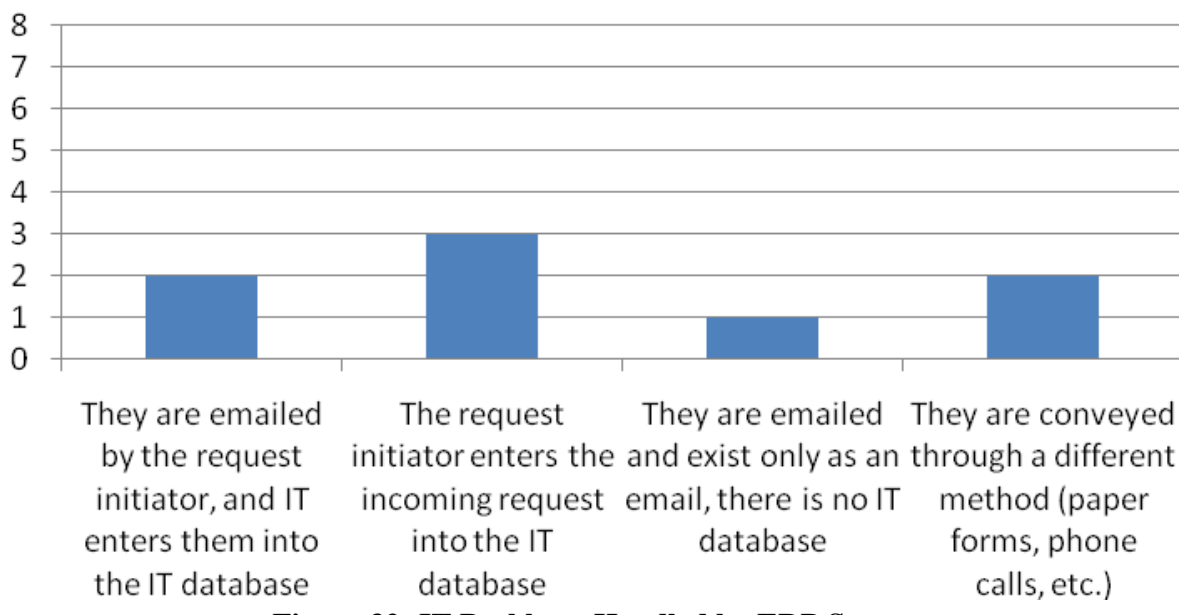

Figure 32: IT Problems Handled by ERP System

Survey results for question 31 indicate that problems reach the IT department through various methods.

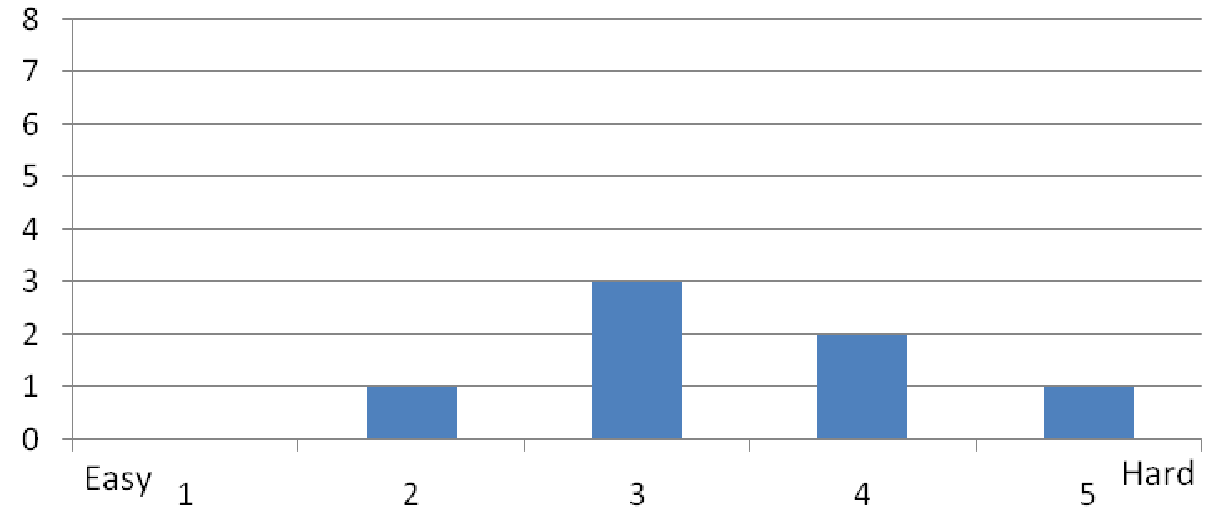

Figure 33: Difficulty of Implementing Additional ERP Modules (Question 33)

Survey results for question 33 show that the subjective difficulty of implementing additional ERP modules can vary greatly depending on the company. 


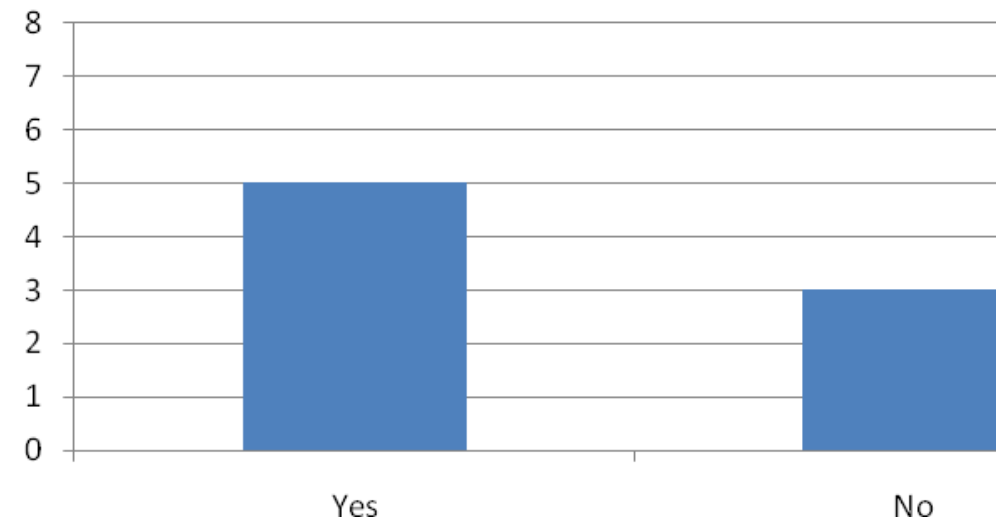

Figure 34: ERP Communication Ability with Supply Chain (Question 34)

Survey results for question 34 indicate that the majority of ERP system are able to communicate with the company's supply chain.

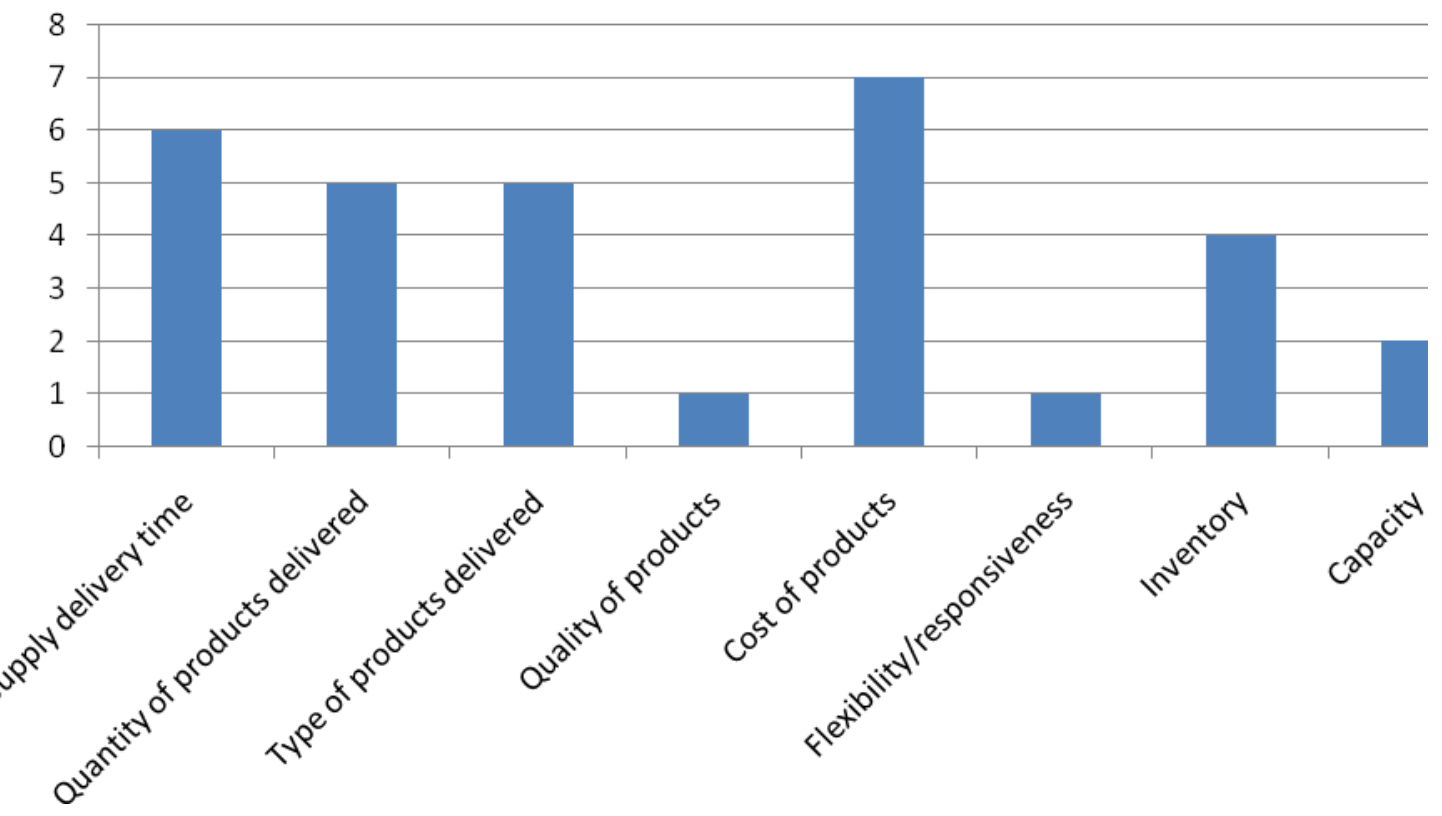

Figure 35: Supply Chain Elements Monitored by ERP (Question 35)

Survey results for question 35 show that the majority supply chain elements are being monitored by the ERP system. 


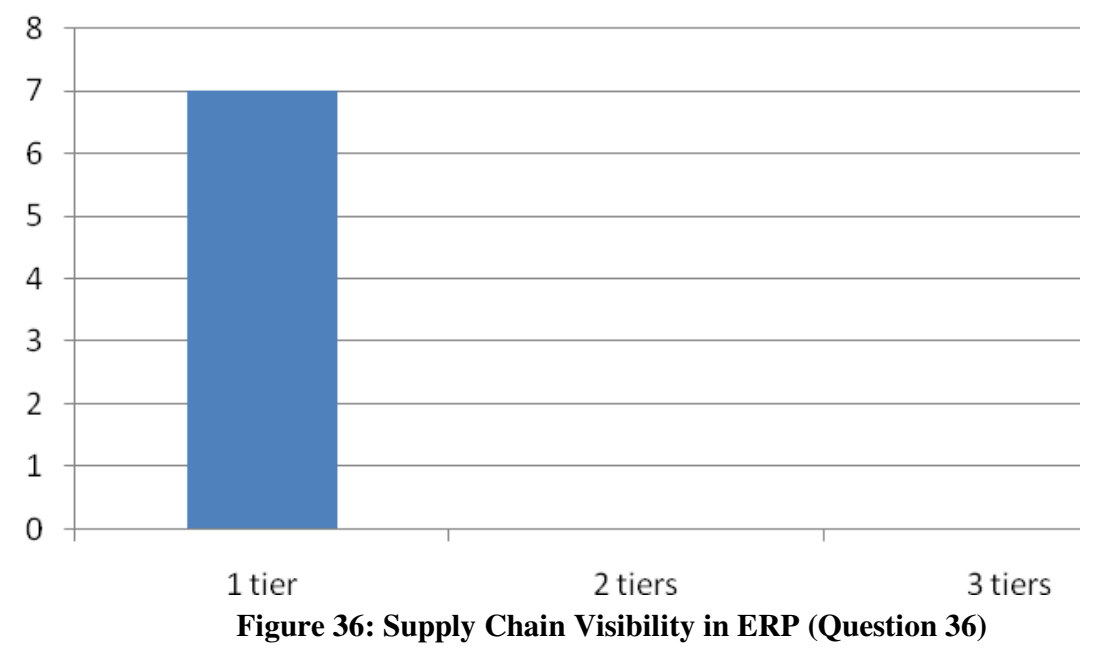

Survey results for question 36 indicate that all respondents have only 1 tier of visibility for their supply chain. The suppliers of their primary suppliers do not have access to supply chain information (2 tier).

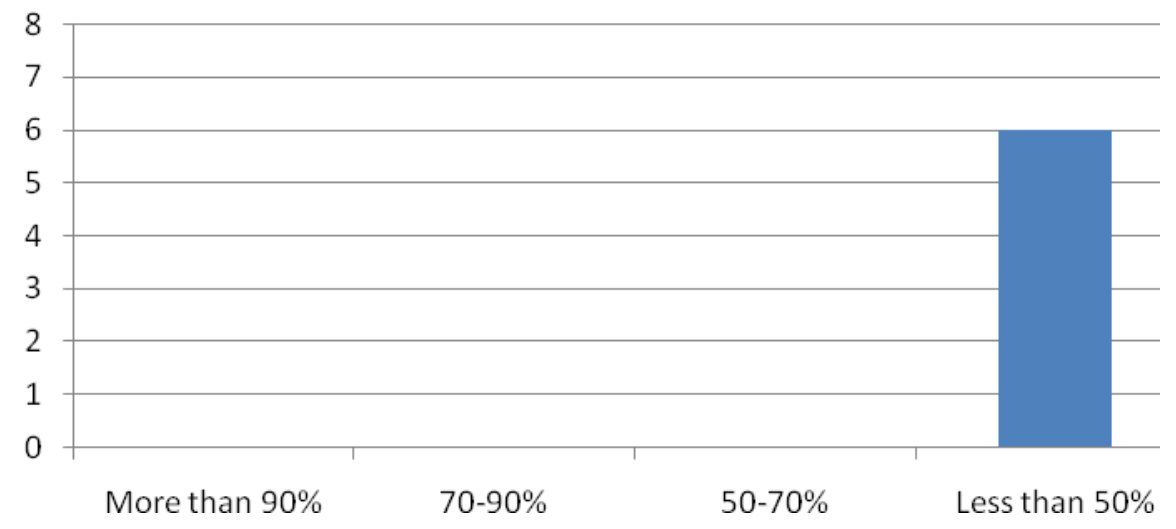

Figure 37: Percent of Companies in Supply Chain Interacting with ERP (Question 37)

Survey results for question 37 show that less than $50 \%$ of the companies within the respondents' supply chain interact with the respondents' ERP systems. 


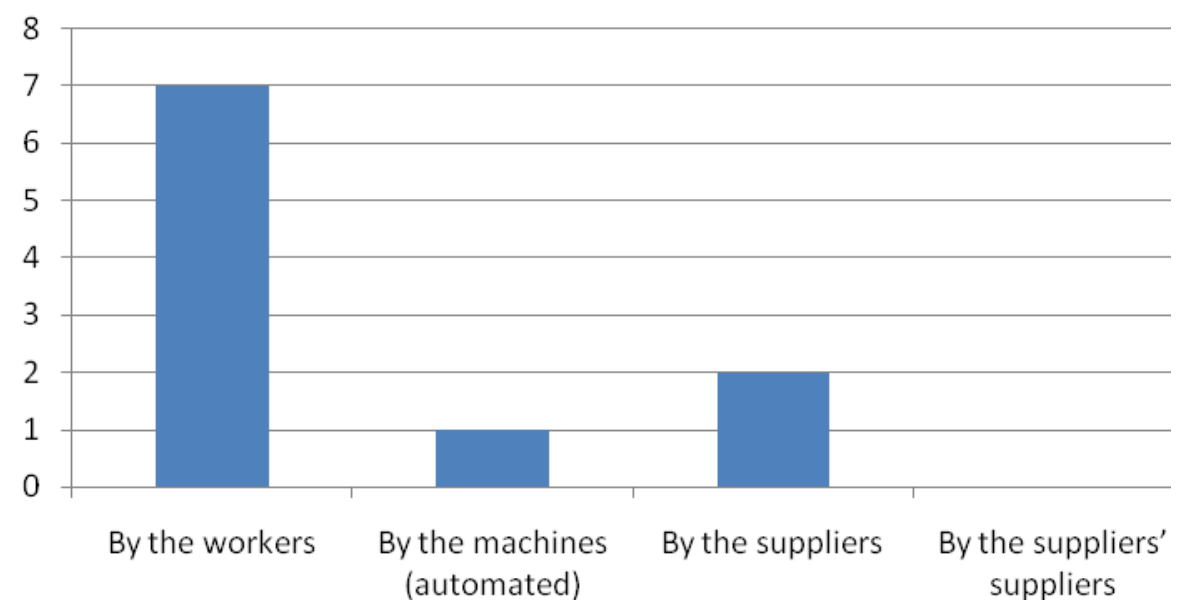

Figure 38: How Information is Input into ERP System (Question 38)

Survey results for question 38 show that the majority of supply chain information is input by workers.

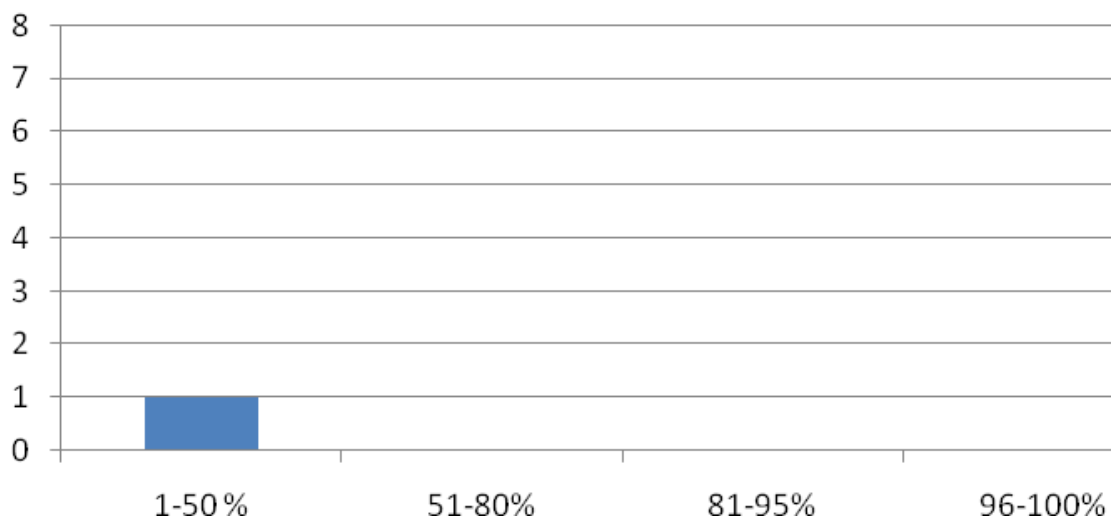

Figure 39: Percent of Supply Chain Information Being Input Automatically (Question 39)

Survey results for question 39 indicate that very little, if any, information is input automatically into the supply chain. 


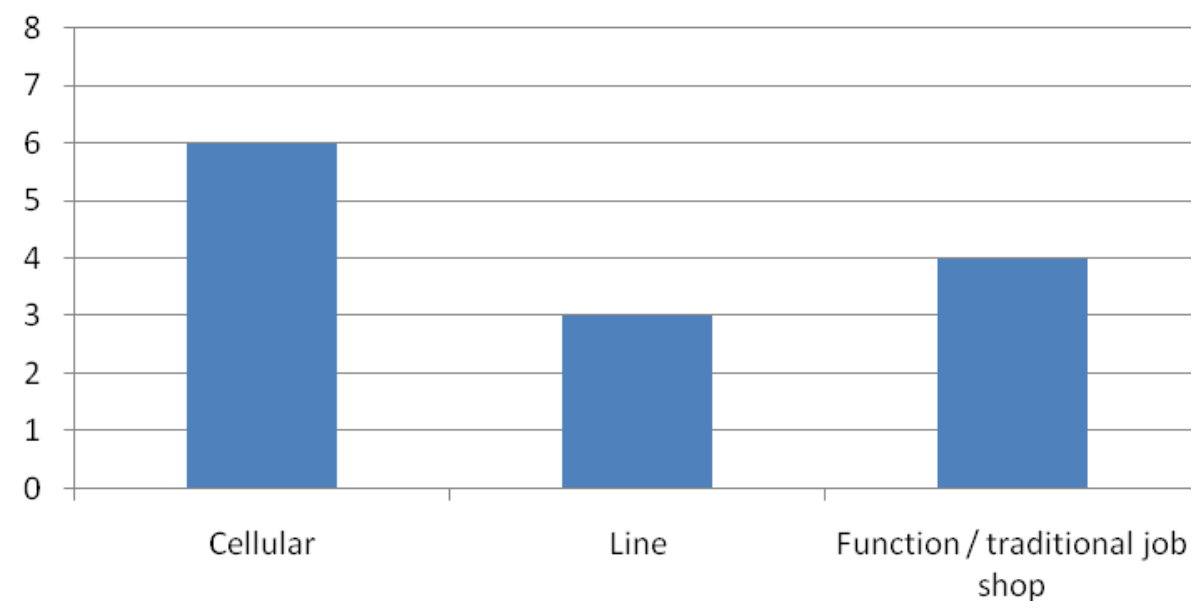

Figure 40: Manufacturing Shop Layout (Question 40)

Survey results for question 40 indicate that the majority of respondents employ a cellular layout with their companies, and that a lot of the companies employ more than one type of manufacturing shop layout.

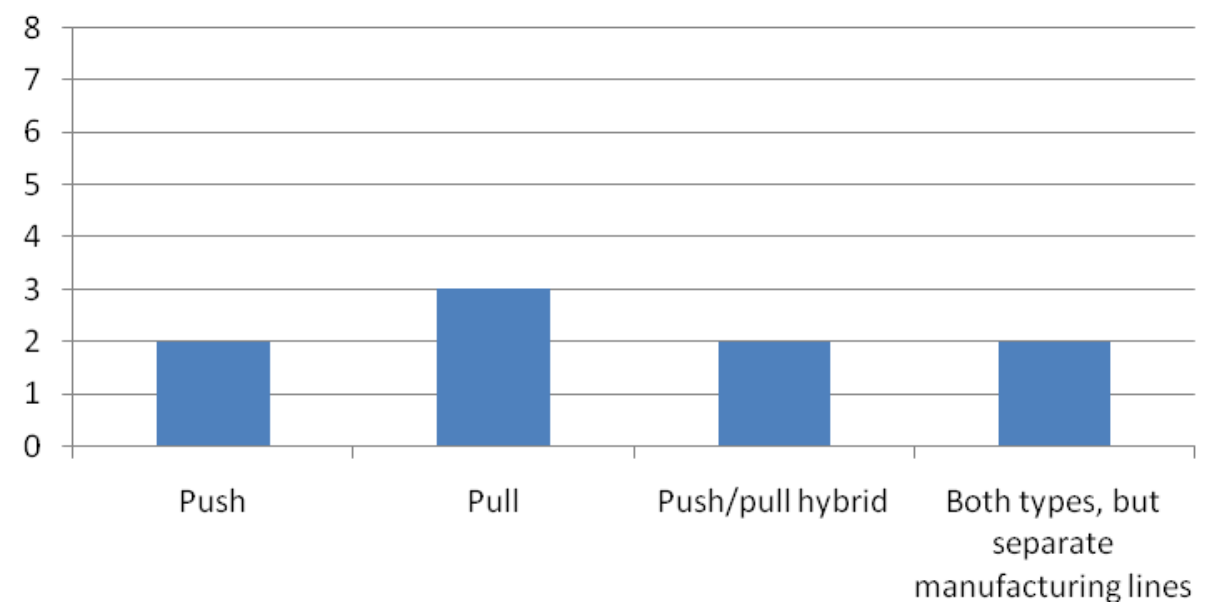

Figure 41: Push or Pull Manufacturing (Question 41)

Survey results for question 41 indicate that respondents are almost evenly distributed between push, pull, push/pull hybrid, and both manufacturing types. 


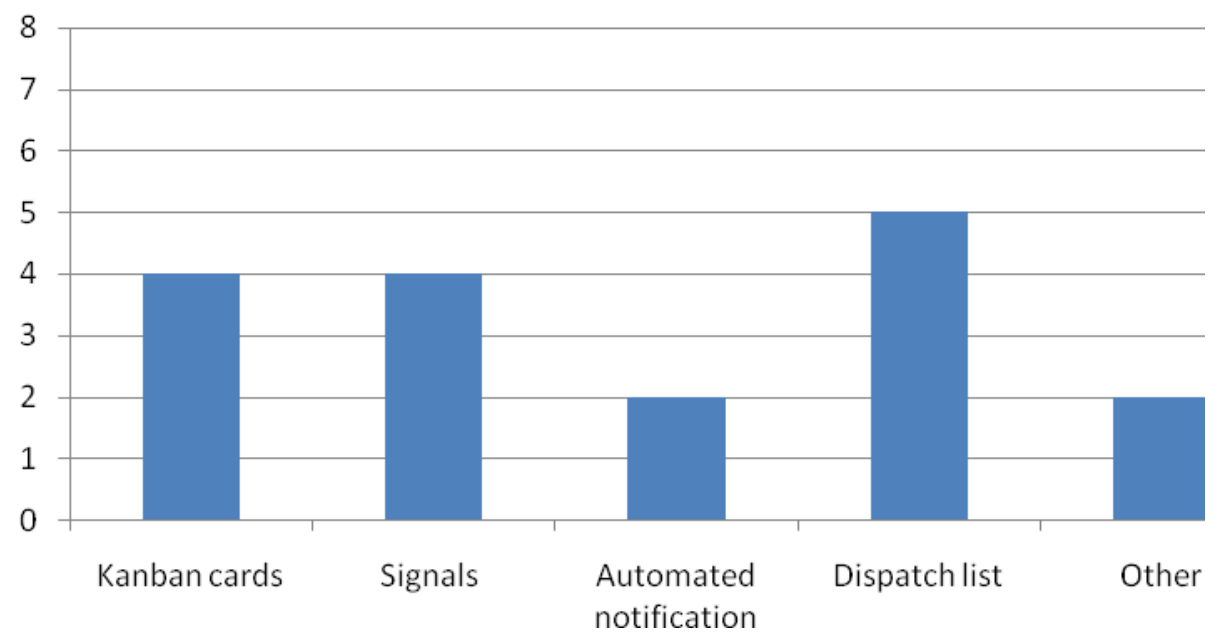

Figure 42: Material Flow through Manufacturing Line (Question 42)

Survey results for question 42 shows that respondents utilize multiple methods for material flow within their manufacturing lines. 50\% use Kanban cards and signals to flow materials down the line.

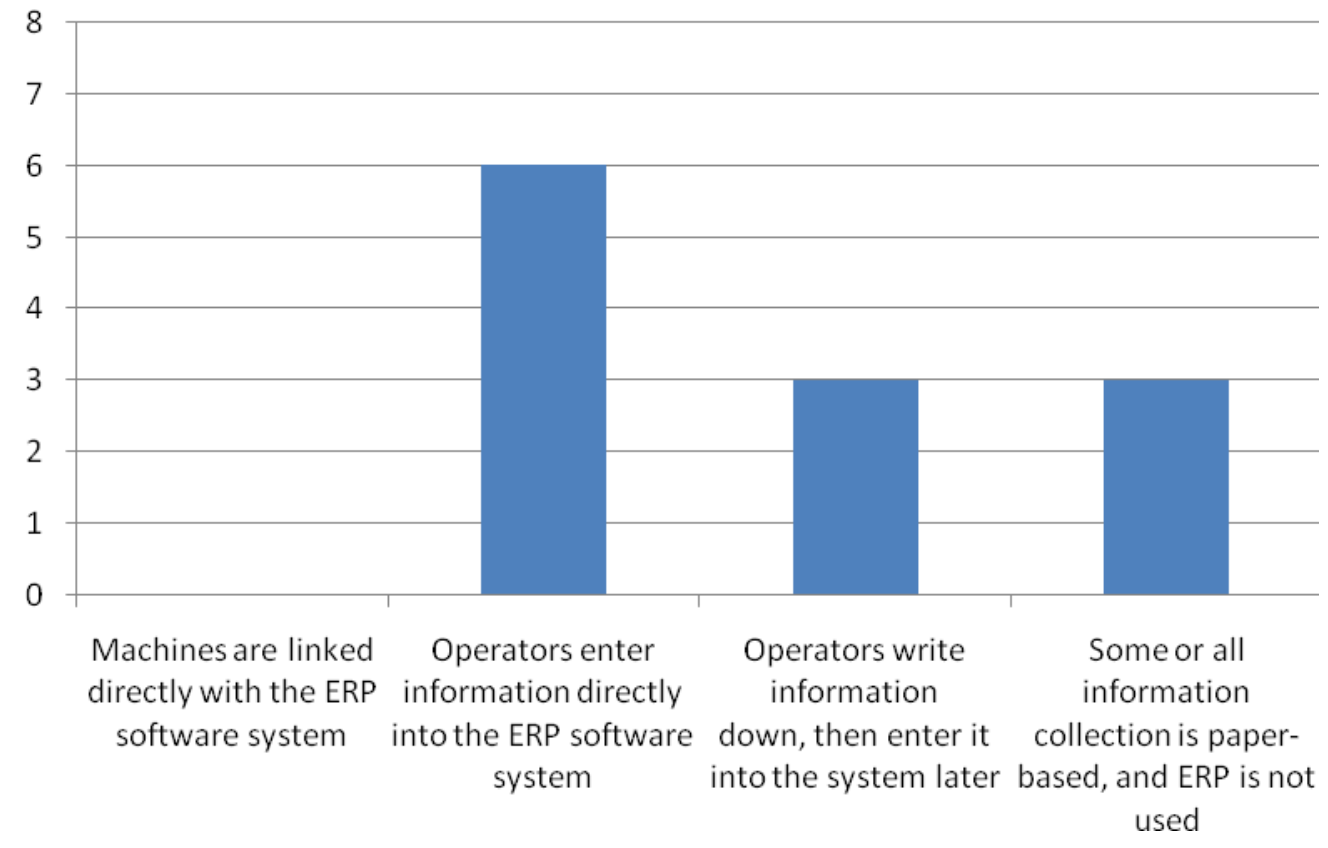

Figure 43: How Production Information is Collected (Question 43)

Survey results for question 43 indicate that all companies use manual means of collecting information from the manufacturing line, as opposed to information being automatically entered into the ERP system. 


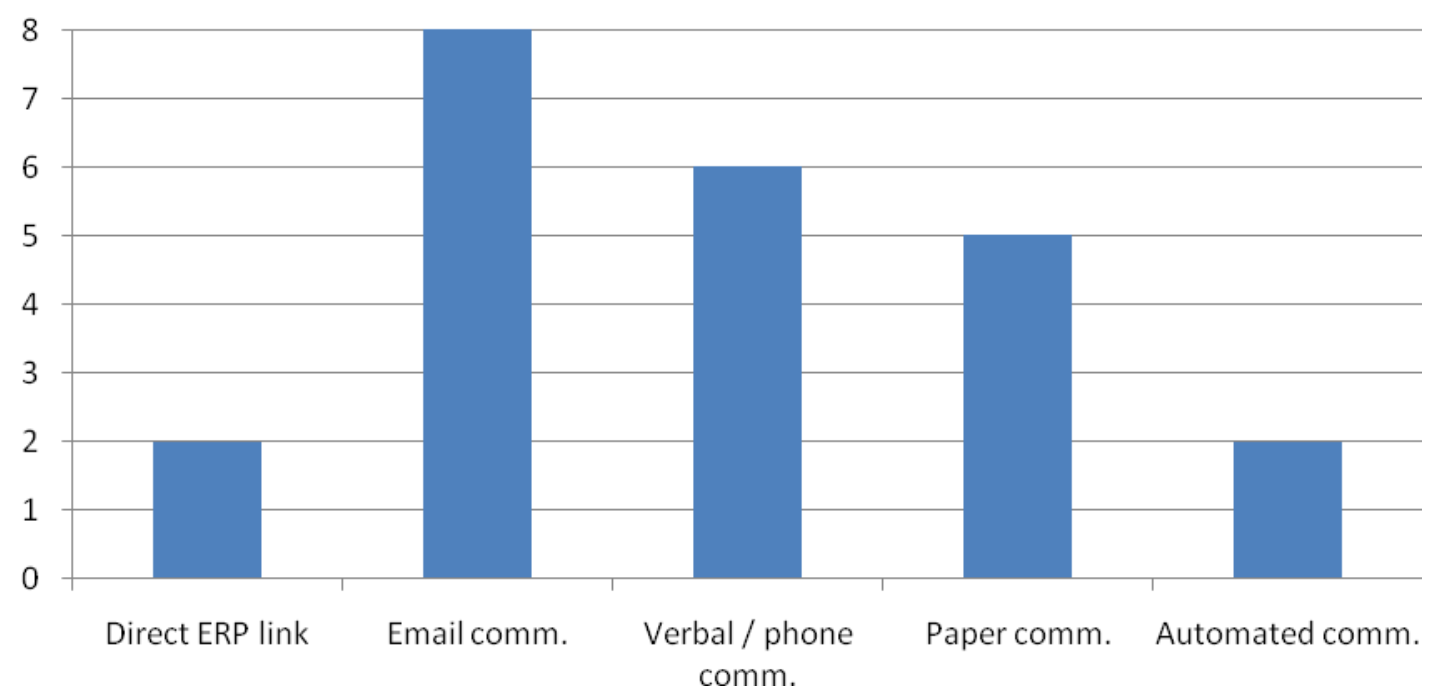

Figure 44: How Quality Control Collects/Disseminates Information (Question 44)

Survey results for question 44 indicate all companies' QC departments use email as a means of collecting and disseminating information, but that other methods are used as well. Only a small portion of respondents use direct ERP links or automated communication to transfer information to other departments.

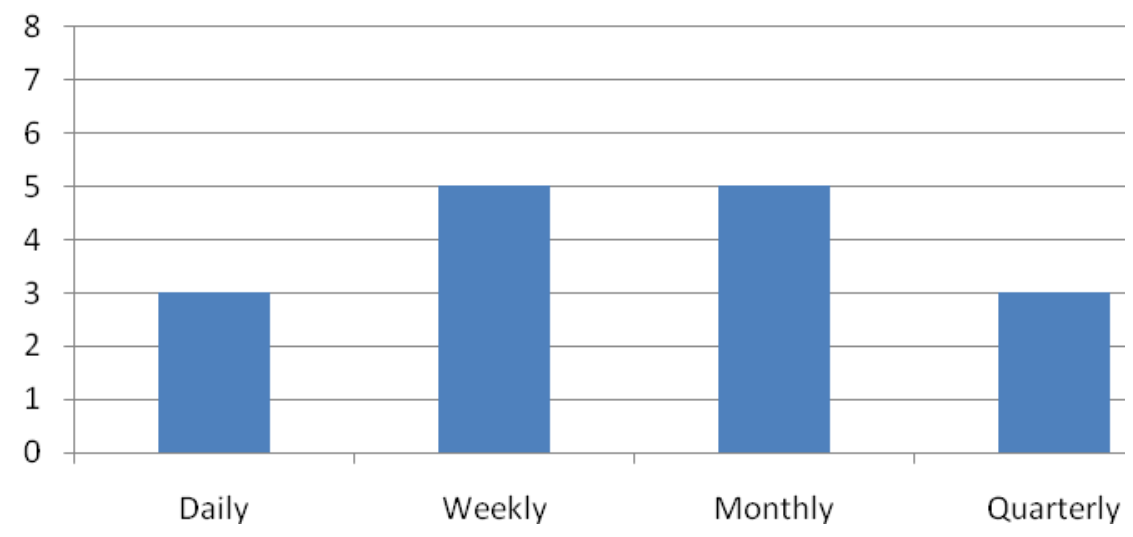

Figure 45: Frequency of Quality Control Report Generation (Question 45)

Survey results for question 45 shows that quality reports are mostly generated on weekly and monthly intervals, but that other intervals are also utilized within the same company. 


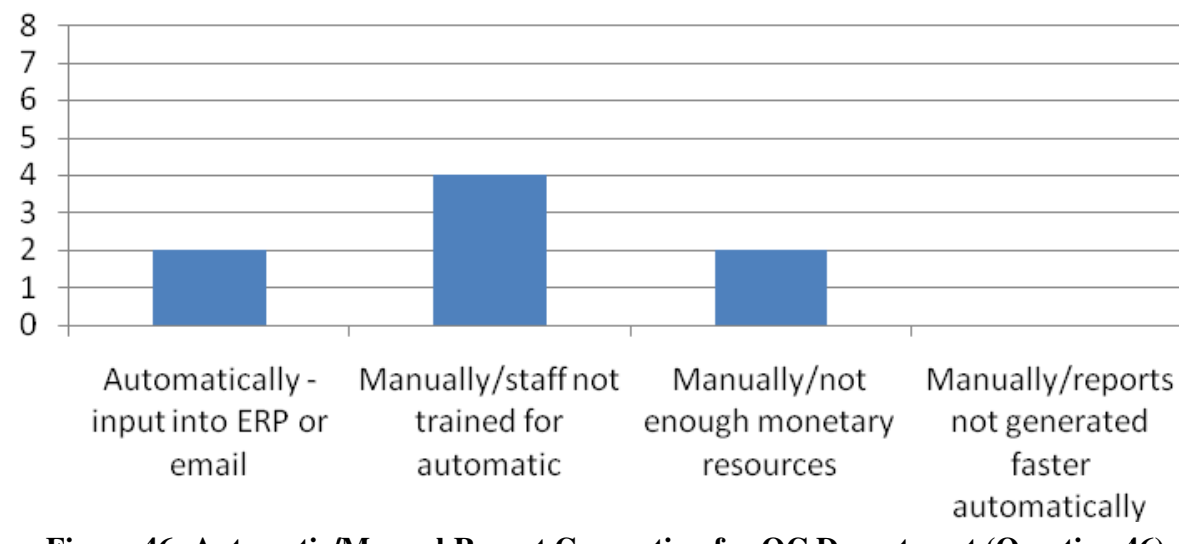

Figure 46: Automatic/Manual Report Generation for QC Department (Question 46)

Survey results for question 46 indicate that the majority of QC reports are generated manually.

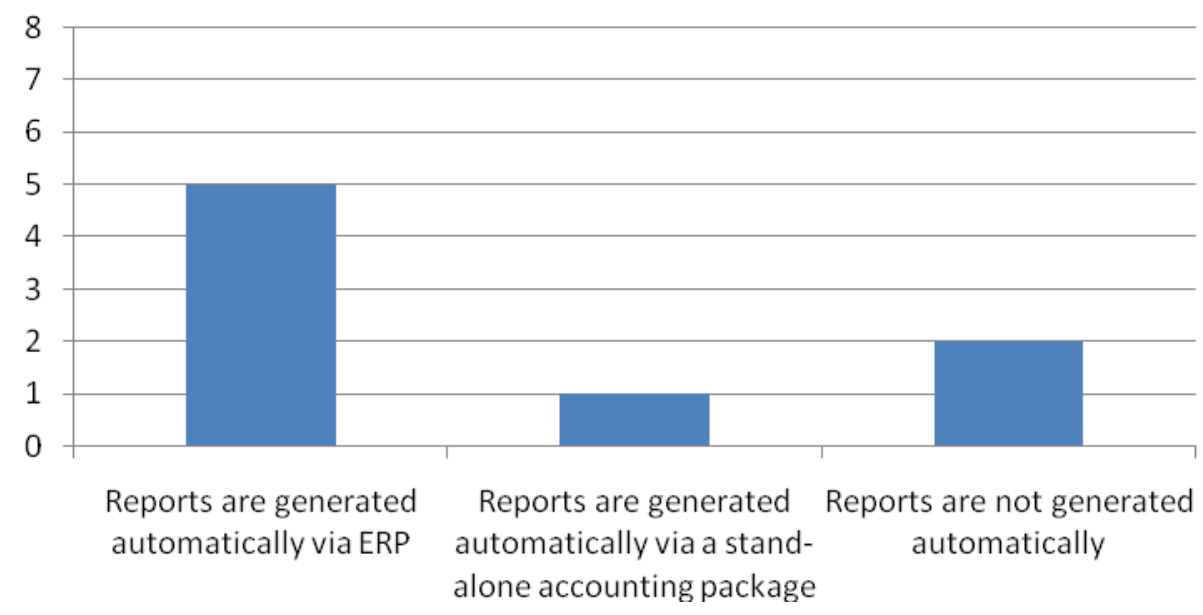

Figure 47: Accounting Reports Generation (Question 47)

Survey results for question 47 show that the majority of accounting reports are generated automatically. However, one respondent also indicated that a stand-alone accounting package was used instead of the ERP system. 


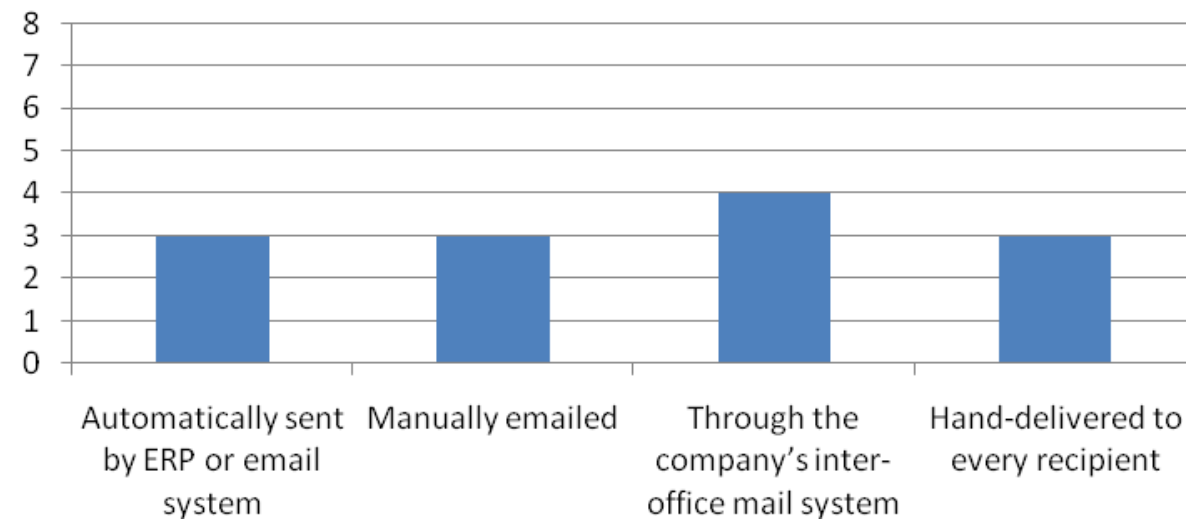

Figure 48: How Accounting Reports Reach Recipients (Question 48)

Survey results for question 48 show that accounting reports reach recipients through a variety of methods. A smaller portion - three of eight - indicated that the reports are sent automatically via ERP or email system.

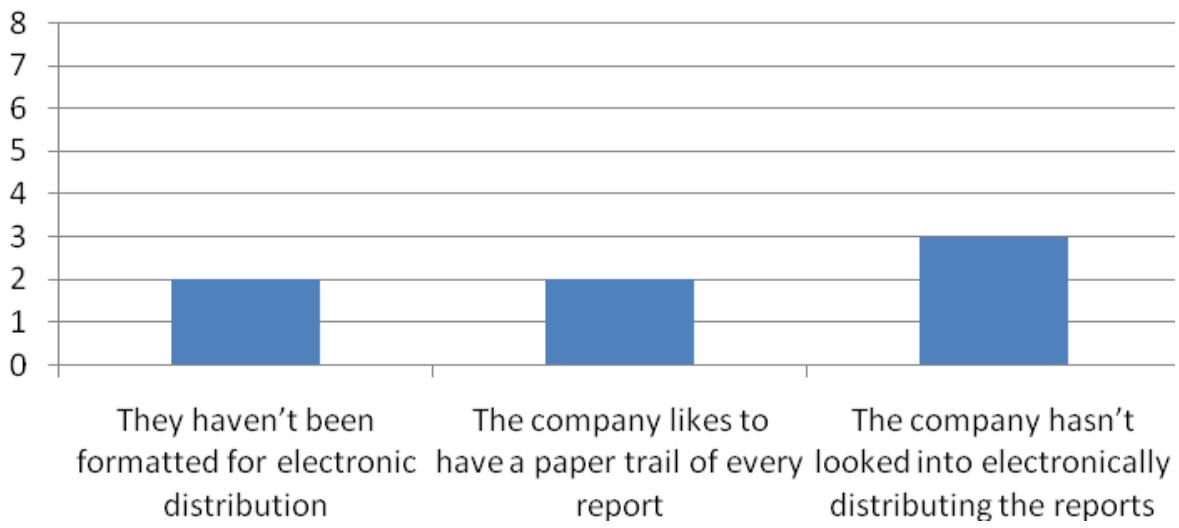

Figure 49: Why Accounting Reports Are Not Sent Electronically (Question 49)

Survey results for question 49 show that a variety of reasons exist why the accounting reports are not sent electronically (and subsequently through automated means). 


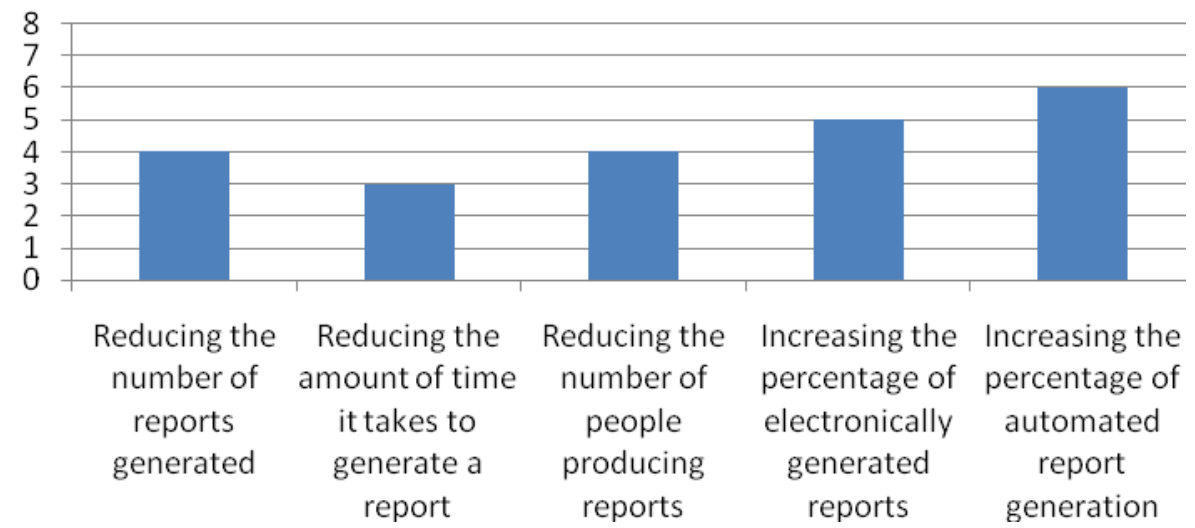

Figure 50: ERP System Improvement Capability for Accounting (Question 50)

Survey results for question 50 indicate that the respondents' ERP systems are capable of improving various aspects of the accounting department. A large percentage of respondents indicated that the ERP system is capable of increasing the percentage of automatically-generated reports.

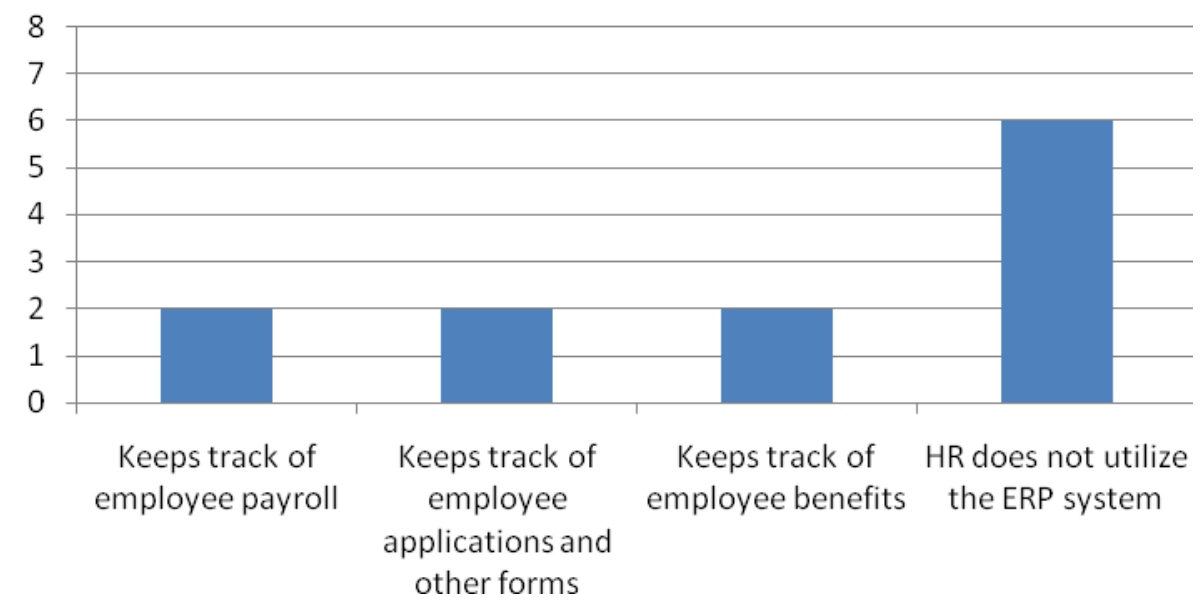

Figure 51: HR Utilization of ERP

Survey results for question 51 shows that the majority of Human Resources departments do not utilize the ERP system at all. 


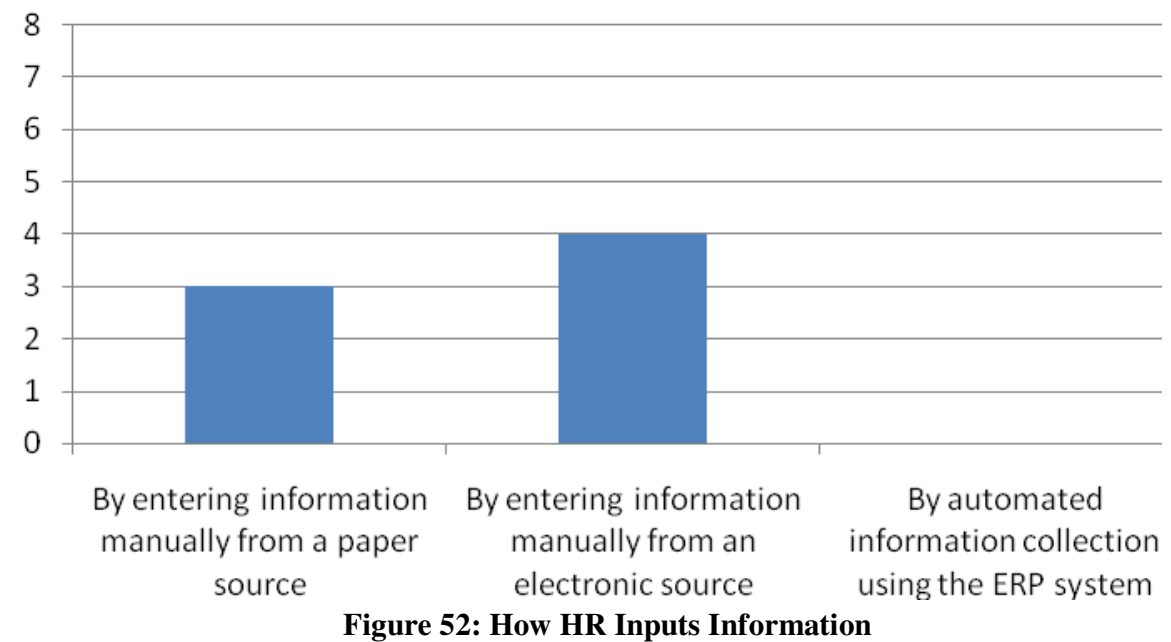

Survey results for question 52 show that HR inputs all their information manually, either from a paper or electronic source.

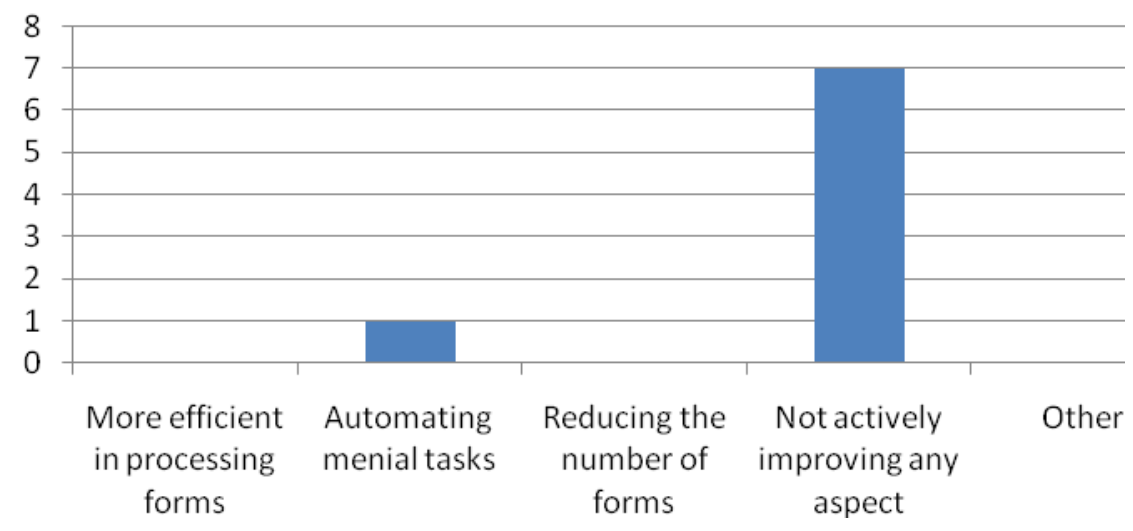

Figure 53: Aspects of HR Being Improved by ERP (Question 53)

Survey results for question 53 indicate that for the majority of respondents, aspects of HR are not being improved by the ERP system. 


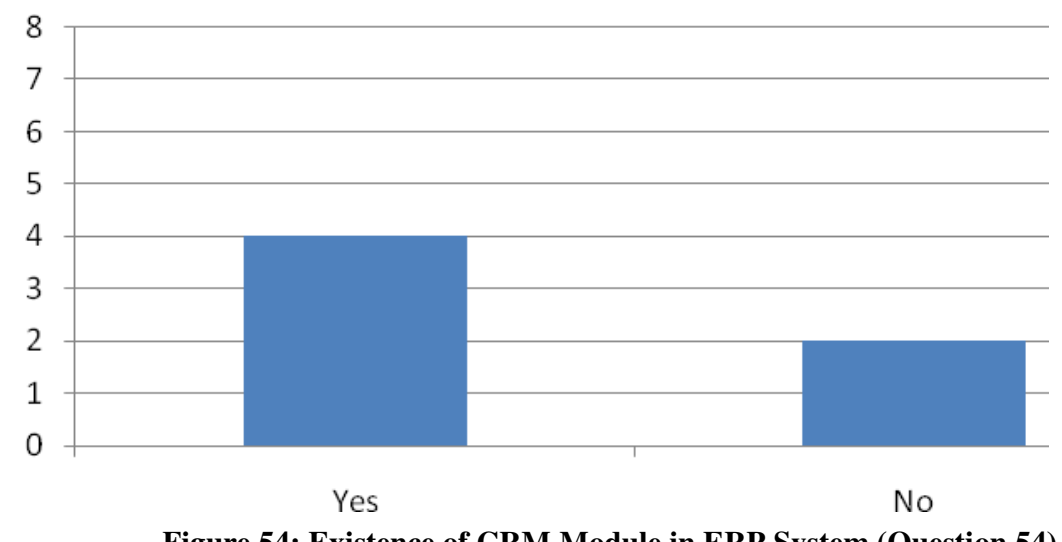

Survey results for question 54 shows that only half of the respondents have a Customer Relations Management module within their ERP system.

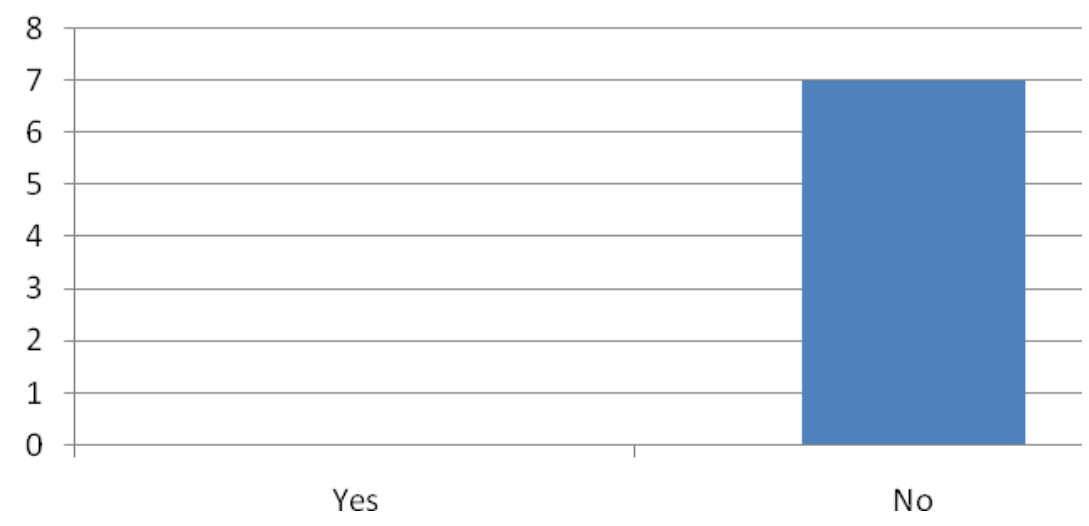

Figure 55: Does ERP System Respond Automatically to Outside Customers (Question 55)

Survey results for question 55 indicate of the respondents that do have a CRM system, none of their systems are capable of automatically responding to requests from outside customers.

\subsection{Correlation Analysis}

The first four questions of the survey - company size, type of manufacturing, manufacturing environment, area of manufacturing - were correlated against all other questions in the survey. The following tables contain the more notable correlations that were observed, 
with a confidence level of $90 \%$ or greater. The top value in each table is the Pearson correlation coefficient, indicating the strength of the correlation and whether the correlation is positive or negative. The bottom value is the p-value for that particular correlation, corresponding to the test of hypothesis for the strength of that correlation (probability of Type 1 Error).

\begin{tabular}{|c|c|c|c|}
\hline & \multicolumn{3}{|c|}{ Question 1: Size of Company } \\
\hline $\begin{array}{c}\text { Significant factor ( } p \leq 0.1) \text { to the size } \\
\text { of company }\end{array}$ & $\begin{array}{l}1-100 \\
\text { employees }\end{array}$ & $\begin{array}{l}100-1000 \\
\text { employees }\end{array}$ & $\begin{array}{l}1000-10,000 \\
\text { employees }\end{array}$ \\
\hline $\begin{array}{l}\text { Quantity of products delivered is } \\
\text { monitored, tracked, and } \\
\text { continuously improved by ERP } \\
\text { system }\end{array}$ & & $\begin{array}{l}0.745 \\
0.034\end{array}$ & \\
\hline $\begin{array}{l}\text { Automated notification for } \\
\text { material/information flowing } \\
\text { through manufacturing line }\end{array}$ & & & $\begin{array}{l}0.655 \\
0.078\end{array}$ \\
\hline $\begin{array}{l}\text { Utilizing a dispatch list for } \\
\text { material/information flowing } \\
\text { through manufacturing line }\end{array}$ & $\begin{array}{r}-0.745 \\
0.034\end{array}$ & & \\
\hline $\begin{array}{l}\text { Quality reports generated } \\
\text { automatically }\end{array}$ & & & $\begin{array}{l}0.655 \\
0.078\end{array}$ \\
\hline $\begin{array}{l}\text { ERP can increase the percentage of } \\
\text { electronically generated reports }\end{array}$ & $\begin{array}{r}-0.745 \\
0.034\end{array}$ & $\begin{array}{l}0.745 \\
0.034\end{array}$ & \\
\hline $\begin{array}{c}\text { HR not improving any aspect of their } \\
\text { department via ERP }\end{array}$ & $\begin{array}{r}-0.655 \\
0.078\end{array}$ & & \\
\hline $\begin{array}{l}\text { ERP automatically responds to } \\
\text { outside customers' requests for } \\
\text { quantity, timing, and flexibility } \\
\text { changes }\end{array}$ & $\begin{array}{r}-0.655 \\
0.078\end{array}$ & $\begin{array}{l}0.655 \\
0.078\end{array}$ & \\
\hline
\end{tabular}

Table 1: Size of Company Correlations

Table 1 is a description of significant size of company correlations. According to the results, a significant number of companies of 100-1000 employees monitor, track, and continuously improve the quantity of products via their ERP system. Given that the number of respondents in the "100-1000 company size" category is also significant (six of eight), a statement can be made about the general population that reflects the results of this particular correlation. 
Reviewing the correlation results as a whole also indicates that a significant number of companies of 1-100 people tend to not utilize their ERP systems in an efficient manner. All of the categories under the 1-100 people column are negatively related. Therefore, small companies tend to not use dispatch lists, increase electronically generated report, and their ERP does not respond to outside customers' requests.

\begin{tabular}{|c|c|c|c|c|}
\hline & \multicolumn{4}{|c|}{ Question 2: Type of Manufacturing } \\
\hline $\begin{array}{l}\text { Significant factor ( } p \leq 0.1 \text { ) to the type } \\
\text { of manufacturing }\end{array}$ & Assembly & Job Shop & Repetitive & $\begin{array}{l}\text { Assemble to } \\
\text { Order }\end{array}$ \\
\hline $\begin{array}{c}76-90 \% \text { of company is practicing lean } \\
\text { concepts }\end{array}$ & $\begin{array}{l}0.745 \\
0.034\end{array}$ & & & \\
\hline Management trained on lean & & $\begin{array}{r}-0.745 \\
0.034 \\
\end{array}$ & & \\
\hline Middle managers trained on lean & & $\begin{array}{l}-0.775 \\
0.024\end{array}$ & & \\
\hline Department managers trained on lean & & $\begin{array}{r}-0.775 \\
0.024\end{array}$ & & \\
\hline Line supervisors trained on lean & & $\begin{array}{r}-0.775 \\
0.024 \\
\end{array}$ & & \\
\hline $\begin{array}{l}76-90 \% \text { of the company had ERP } \\
\text { implemented }\end{array}$ & & & $\begin{array}{l}0.655 \\
0.078\end{array}$ & \\
\hline ERP implementation took $5+$ years & & & $\begin{array}{l}0.655 \\
0.078\end{array}$ & \\
\hline $\begin{array}{l}\text { Managers manually enter information } \\
\text { into the ERP system }\end{array}$ & & $\begin{array}{r}-0.745 \\
0.034\end{array}$ & & \\
\hline $\begin{array}{l}\text { Quality of products delivered is } \\
\text { monitored, tracked, and continuously } \\
\text { improved by ERP system }\end{array}$ & & & $\begin{array}{l}0.655 \\
0.078\end{array}$ & \\
\hline $\begin{array}{c}\text { Less than } 50 \% \text { of the supply chain } \\
\text { companies interact with the company } \\
\text { ERP system }\end{array}$ & $\begin{array}{r}-0.745 \\
0.034\end{array}$ & & & \\
\hline Push type of manufacturing system & & & & $\begin{array}{r}-0.745 \\
0.034\end{array}$ \\
\hline $\begin{array}{l}\text { Push/pull hybrid manufacturing } \\
\text { system }\end{array}$ & $\begin{array}{l}0.745 \\
0.034\end{array}$ & & & \\
\hline $\begin{array}{l}\text { Utilizing signals (hand, voice, } \\
\text { electronic) for material/information } \\
\text { flowing through manufacturing line }\end{array}$ & & & & $\begin{array}{l}0.775 \\
0.024\end{array}$ \\
\hline $\begin{array}{c}\text { Production information is collected by } \\
\text { operators writing down information } \\
\text { and entering it into the ERP system at } \\
\text { a later time }\end{array}$ & & & $\begin{array}{l}0.745 \\
0.034\end{array}$ & \\
\hline
\end{tabular}




\begin{tabular}{|c|c|c|}
\hline $\begin{array}{l}\text { Quality reports entered manually } \\
\text { because staff is not trained to perform } \\
\text { the work through automatic means }\end{array}$ & & $\begin{array}{c}-0.775 \\
0.024\end{array}$ \\
\hline $\begin{array}{l}\text { Acctg reports reach recipients through } \\
\text { company's inter-office mail system }\end{array}$ & & $\begin{array}{l}0.775 \\
0.024\end{array}$ \\
\hline $\begin{array}{l}\text { ERP can increase the percentage of } \\
\text { automatically generated reports }\end{array}$ & $\begin{array}{r}-0.745 \\
0.034\end{array}$ & \\
\hline
\end{tabular}

Table 2: Type of Manufacturing Correlations

Table 2 is a description of significant types of manufacturing correlations. According to the results, a significant number of job shops do not train their management and line supervisors on lean concepts. However, the same job shops are also indicate that their management automatically enters information into the ERP system. Assembly manufacturing companies tend to have more positive correlations. A significant number of assembly manufacturers have reported that $76-90 \%$ of the company practices lean concepts, and that more than $50 \%$ of their supply chain companies interact with the respondents' ERP systems. They also tend to have a push/pull hybrid manufacturing system, possibly employing the best of both methods to be as efficient as possible.

\begin{tabular}{|c|c|c|}
\cline { 2 - 3 } \multicolumn{1}{c|}{} & \multicolumn{2}{c|}{ Question 3: Manufacturing Environment } \\
\hline Significant factor $(p \leq 0.1)$ to the & Build to stock & Build to order \\
manufacturing environment & & \\
\hline 51-75\% of the company is practicing lean & -0.745 & 0.034 \\
\hline Push type of manufacturing system & & -0.655 \\
& & 0.078 \\
\hline Utilizing automated (computerized) & -0.745 & \\
notification for material/information flowing & 0.034 & \\
through manufacturing line & & \\
\hline QC collects/disseminates information via & -0.745 & \\
direct ERP link with other departments & 0.034 & \\
\hline Quality reports are generated automatically & -0.745 & \\
& 0.034 & \\
\hline
\end{tabular}

Table 3: Manufacturing Environment Correlations

Table 3 is a description of significant manufacturing environment correlations. According to the results, a significant number of build to stock companies do not utilize a number of 
processes that would improve the efficacy of their ERP systems: they do not utilize automated notification for material/information flow through manufacturing line, quality control does not have direct ERP links with other departments, and quality reports are not generated automatically. A significant amount of build to order companies do not utilize push systems, indicating that they instead employ a pull, push/pull hybrid, or combined push and pull manufacturing system.

\begin{tabular}{|c|c|c|c|}
\hline & \multicolumn{3}{|c|}{ Question 4: Area of Manufacturing } \\
\hline $\begin{array}{l}\text { Significant factor }(p \leq 0.1) \text { to the area of } \\
\text { manufacturing }\end{array}$ & $\begin{array}{l}\text { Heavy } \\
\text { Industry }\end{array}$ & $\begin{array}{l}\text { Medium size } \\
\text { manufacturing }\end{array}$ & $\begin{array}{c}\text { Small } \\
\text { component } \\
\text { manufacturing }\end{array}$ \\
\hline $\begin{array}{l}51-75 \% \text { of the company is practicing lean } \\
\text { concepts }\end{array}$ & & $\begin{array}{r}-0.745 \\
0.034\end{array}$ & \\
\hline $76-90 \%$ of the company had ERP implemented & & & $\begin{array}{l}0.655 \\
0.078\end{array}$ \\
\hline $\begin{array}{l}\text { ERP implementation exceeded the budget, but } \\
\text { met the time allotted }\end{array}$ & $\begin{array}{l}0.655 \\
0.078\end{array}$ & & \\
\hline $\begin{array}{l}\text { ERP implementation exceeded the budget, and } \\
\text { exceeded the time allotted }\end{array}$ & & $\begin{array}{l}0.775 \\
0.024\end{array}$ & \\
\hline ERP implementation did not exceed the budget & & $\begin{array}{r}-0.745 \\
0.034\end{array}$ & \\
\hline $\begin{array}{c}\text { Quality of products delivered is monitored, } \\
\text { tracked, and continuously improved by ERP } \\
\text { system }\end{array}$ & & & $\begin{array}{l}0.655 \\
0.078\end{array}$ \\
\hline $\begin{array}{l}\text { Cost of products delivered is monitored, tracked, } \\
\text { and continuously improved by ERP system }\end{array}$ & & & $\begin{array}{r}-0.655 \\
0.078\end{array}$ \\
\hline $\begin{array}{c}\text { Inventory is monitored, tracked, and continuously } \\
\text { improved by ERP system }\end{array}$ & & $\begin{array}{r}-0.775 \\
0.024 \\
\end{array}$ & \\
\hline $\begin{array}{c}\text { Capacity is monitored, tracked, and continuously } \\
\text { improved by ERP system }\end{array}$ & & $\begin{array}{r}-0.745 \\
0.034 \\
\end{array}$ & \\
\hline $\begin{array}{l}\text { Automated notification for material/information } \\
\text { flowing through manufacturing line }\end{array}$ & & $\begin{array}{r}-0.745 \\
0.034 \\
\end{array}$ & \\
\hline $\begin{array}{l}\text { QC collects/disseminates information via direct } \\
\text { ERP link with other departments }\end{array}$ & & $\begin{array}{r}-0.745 \\
0.034 \\
\end{array}$ & \\
\hline Quality reports are generated automatically & & $\begin{array}{r}-0.745 \\
0.034\end{array}$ & \\
\hline $\begin{array}{l}\text { Accounting reports are hand-delivered to every } \\
\text { recipient }\end{array}$ & & & $\begin{array}{l}0.745 \\
0.034\end{array}$ \\
\hline
\end{tabular}

Table 4: Area of Manufacturing Correlations 
Table 4 is a description of significant area of manufacturing correlations. According to the results, a significant number of medium size manufacturing companies are not practicing methods that would improve their effectiveness. The results suggest that they do not monitor, track, and continuously improve inventory and capacity, that automated notification is not present in the manufacturing line, that quality control does not collect and disseminate information via ERP, and that quality reports are not generated automatically. The results also suggest that medium size manufacturing companies also exceeded both the budget and time allotted for ERP implementation, as evident by both columns four and five of Table 4 .

A significant number of small component manufacturing firms indicate that at least 7690\% of the company had ERP implemented, and that quality of products delivered is monitored, tracked, and continuously improved by the ERP system. However, the same results also indicate that the cost of products delivered is not monitored or tracked, showing that there are areas of improvement for all areas of manufacturing. 


\begin{tabular}{|c|c|c|c|c|c|c|c|c|}
\hline \multirow[b]{2}{*}{ Significant factor $(p \leq 0.1)$ to the } & \multicolumn{2}{|c|}{ Question 1} & \multicolumn{2}{|c|}{ Question 2} & \multirow{2}{*}{$\begin{array}{l}\text { Question } 3 \\
\text { Build to } \\
\text { stock }\end{array}$} & \multicolumn{3}{|c|}{ Question 4} \\
\hline & $1-100$ & $1 \mathrm{~K}-10 \mathrm{~K}$ & $\begin{array}{l}\text { Repe } \\
\text { titive }\end{array}$ & $\begin{array}{l}\text { Assemble } \\
\text { to Order }\end{array}$ & & $\begin{array}{l}\text { Heavy } \\
\text { Industry }\end{array}$ & $\begin{array}{l}\text { Medium } \\
\text { size } \mathrm{mfg}\end{array}$ & $\begin{array}{c}\text { Small } \\
\text { cmpnt mfg }\end{array}$ \\
\hline $\begin{array}{l}\text { Provides for continuous } \\
\text { measurement and reporting of } \\
\text { setup times }\end{array}$ & & & & & & $\begin{array}{l}0.745 \\
0.034\end{array}$ & & \\
\hline $\begin{array}{l}\text { Compares actual lot size to } \\
\text { planned lot size }\end{array}$ & & & $\begin{array}{l}0.655 \\
0.078\end{array}$ & & & & & $\begin{array}{l}0.655 \\
0.078\end{array}$ \\
\hline $\begin{array}{l}\text { Notifies the supply chain when a } \\
\text { visual determination reorder point } \\
\text { is reached }\end{array}$ & $\begin{array}{c}-0.745 \\
0.034\end{array}$ & & & & & & & \\
\hline $\begin{array}{l}\text { Supports electronic transfer of } \\
\text { replenishment signals }\end{array}$ & $\begin{array}{l}-0.745 \\
0.034\end{array}$ & & & & & & & \\
\hline $\begin{array}{l}\text { Supports electronic work } \\
\text { instructions with color coding, } \\
\text { digital photos, or video }\end{array}$ & & & & & $\begin{array}{r}-0.745 \\
0.034\end{array}$ & & & \\
\hline $\begin{array}{l}\text { Supports electronic, color-coded } \\
\text { work instructions }\end{array}$ & & & & & $\begin{array}{r}-0.745 \\
0.034\end{array}$ & & & \\
\hline $\begin{array}{l}\text { Supports measurement of safety } \\
\text { stock by line or cell }\end{array}$ & & $\begin{array}{l}0.655 \\
0.078\end{array}$ & & & $\begin{aligned}-0.745 \\
0.034\end{aligned}$ & & $\begin{array}{r}-0.745 \\
0.034\end{array}$ & \\
\hline $\begin{array}{l}\text { Tracks actual inventory turnover } \\
\text { vs. planned inventory turnover }\end{array}$ & & & $\begin{array}{l}0.745 \\
0.034 \\
\end{array}$ & & & $\begin{array}{l}0.745 \\
0.034\end{array}$ & & \\
\hline $\begin{array}{l}\text { Compares actual lead time vs. } \\
\text { planned lead time }\end{array}$ & & & $\begin{array}{l}0.745 \\
0.034\end{array}$ & & & & & \\
\hline
\end{tabular}

Table 5: Lean ERP Questions (Q27) Correlated to Q1 - Q4

Question 27 was analyzed separately from the other questions, due to its large size and significance. Out of the twenty-two mini-questions that comprise Question 27, eleven were found to have significant correlations to some of the answers in Questions 1 through 4. Answers that had no correlations (for example Question 1, 100 - 1,000 employees) were omitted because there was no value in discussing them. The results indicate that a significant number build to stock companies have no support for electronic work instructions, and do not support measurement of safety stock by line or cell. Small companies of $1-100$ do not notify the supply chain when a reorder point is reached, and do not support electronic transfer of replenishment signals. 
Repetitive manufacturers did have significant factors working in their favor. A p-value of 0.078 indicates that repetitive manufacturers compare actual lot size to planned lot size, and utilize their ERP systems to track actual inventory turnover vs. planned inventory turnover, and compare actual lead time vs. planned lead time.

\subsection{Test of Proportion}

Six out of eight, seven out of eight, and eight out of eight responses were analyzed with the test of proportions. The charts below represent all answers that fell within one of those three categories. The test of proportions was calculated by pushing the hypothesized proportion as high as possible without falling beneath the $90 \%$ confidence level. All three stated with a hypothesized proportion of $\mathrm{p}=0.50$ vs. $\mathrm{p}>0.50$, and adjusted accordingly. Answers that had six out of eight respondents reply positively indicated that the null hypothesis failed to be rejected at

0.46 . The samples show that the population practicing these methods is significantly larger than $46 \%$. 


\begin{tabular}{|c|c|c|}
\hline 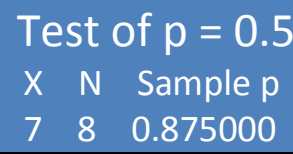 & $\begin{array}{l}9 \text { vs } p>0.59 \text { for } \\
90 \% \text { Lower Bound } \\
0.593755\end{array}$ & $\begin{array}{l}7 \text { out of } 8 \text { responses } \\
\text { Exact P-Value } \\
0.096\end{array}$ \\
\hline \multicolumn{3}{|c|}{ Build to order manufacturing environment } \\
\hline \multicolumn{3}{|c|}{ Manufacturing was given training on ERP } \\
\hline \multicolumn{3}{|c|}{$\begin{array}{l}\text { ERP modules implemented into the ERP system because they were deemed necessary by the } \\
\text { company }\end{array}$} \\
\hline \multicolumn{3}{|c|}{ Material division is using the ERP system } \\
\hline \multicolumn{3}{|c|}{ Cost of products is monitored, tracked, and continuously improved by ERP system } \\
\hline \multicolumn{3}{|c|}{ 1-tier supplier visibility offered by ERP system (as opposed to 2- or 3-tiers) } \\
\hline \multicolumn{3}{|c|}{ Workers input information manually for the supply chain section of the ERP system } \\
\hline \multicolumn{3}{|c|}{ HR is not actively improving any aspect of the department via the ERP system } \\
\hline \multicolumn{3}{|c|}{$\begin{array}{l}\text { The ERP system does not automatically respond to outside customers' requests for quantity, timing, } \\
\text { and flexibility changes }\end{array}$} \\
\hline
\end{tabular}

Table 7: Test of Proportions for 7 out of 8 Responses

Table 7 shows the result of test of proportions for seven out of eight survey responses. The test indicates that a population significantly larger than $59 \%$ gave ERP training to the manufacturing department, that the material division is using the ERP system, and that cost of products is monitored, tracked, and continuously improved by the ERP system. However, the same population also offer only 1-tier visibility, the workers input supply chain information manually, and the ERP system does not automatically respond to outside customers' requests for quantity, timing, and flexibility changes. 


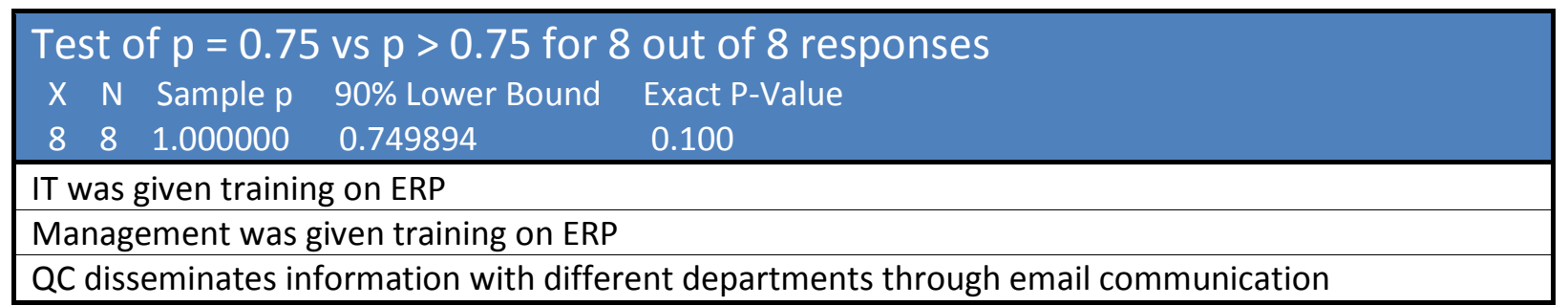

Table 8: Test of Proportions for 8 out of 8 Responses

Table 8 shows the result of test of proportions for eight out of eight survey responses.

The test indicates that a population significantly larger than $75 \%$ gave training to both management and the IT department. The same population also indicates that the quality control department disseminates information through email communication. 


\subsection{Chi-Square Analysis}

A Chi-Square analysis has been used to see if any evidence exists for association between certain lean performance factors outlined in Question 27 and other survey questions. Due to the restrictions outlined in Analysis Procedures section, only a small number of questions were eligible for Chi-Square analysis. Unfortunately none of the results below allowed the null hypothesis to be rejected, indicating an association between the factors. Some of the Chi-Square analyses also provided identical results. These analyses were condensed into one representative chart for brevity purposes.

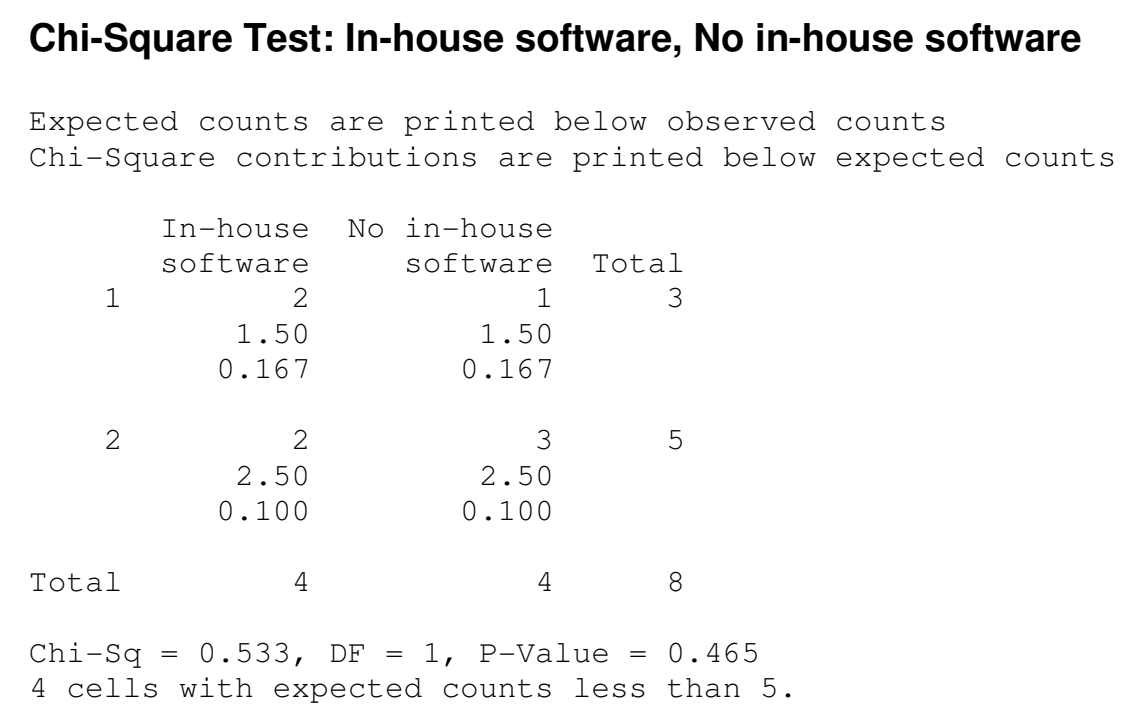

Figure 56: Chi-Square Analysis of Q27 Answer 1 with Question 24

Figure 56 above represents the results for this Chi-Square analysis. Question 24 asks if any in-house software tools are being utilized by the employees in order to avoid using the tools in the ERP system. Question 1 asks if the ERP system provides for continuous measurement and reporting of setup times. A p-value of 0.465 indicates there is no evidence to associate Question 1 with Question 27. 


\section{Chi-Square Test: In-house software, No in-house software}

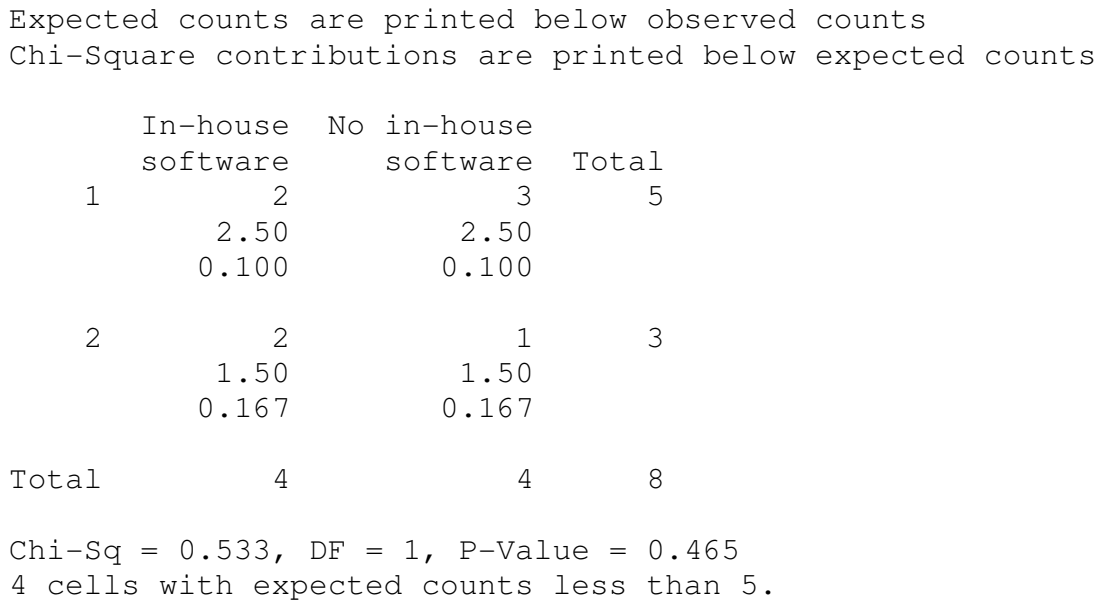

Figure 57: Chi-Square Analysis of Q27 Answer 6 and 7 vs Question 24

The Chi-Square test for Answers 6 and 7 was identical; Figure 57 above represents the results for both. Question 27, Answer 6 asks if the supply chain is notified when a reorder point is reached, whereas Answer 7 asks if electronic transfer of replenishment signals is supported. A p-value of 0.465 indicates there is no evidence to associate either Question 6 or 7 with Question 27.

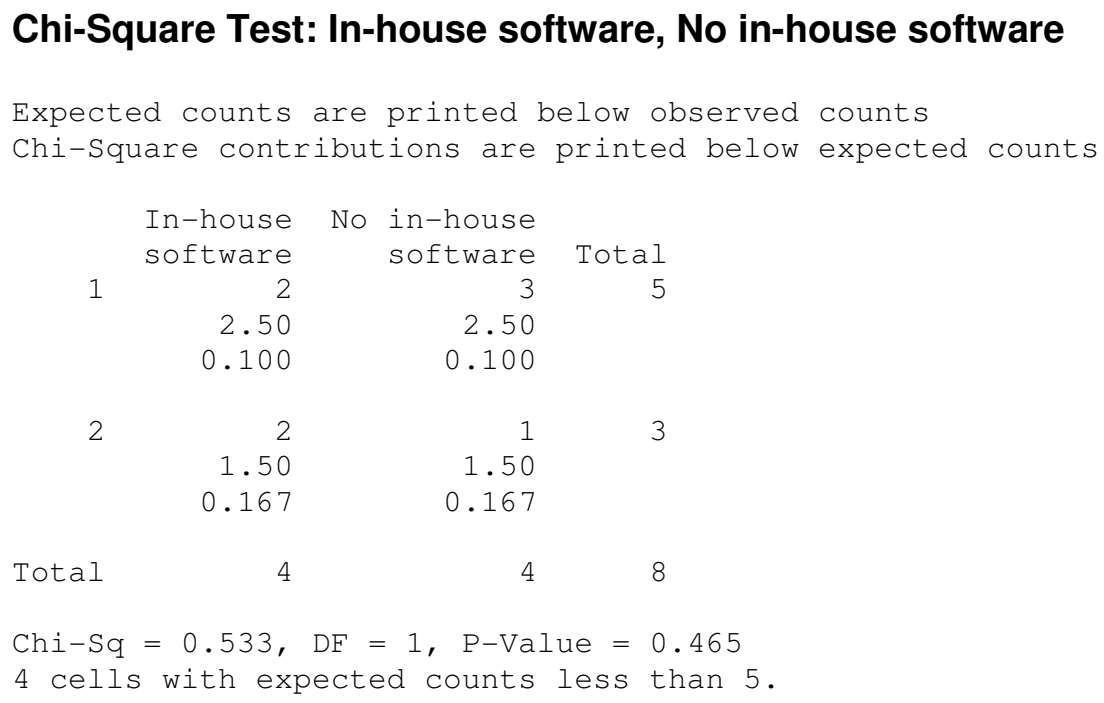

Figure 58: Chi-Square Analysis of Q27, Answer 8 with Question 24 
The Chi-Square test for Answer 8 is very similar to that of Answers 6 and 7, but not exactly the same. Figure 58 above represents the results for this analysis. Question 8 asks if electronic printing and posting of kanban signals is supported. A p-value of 0.465 indicates there is no evidence to associate Question 8 with Question 27.

\section{Chi-Square Test: In-house software, No in-house software}

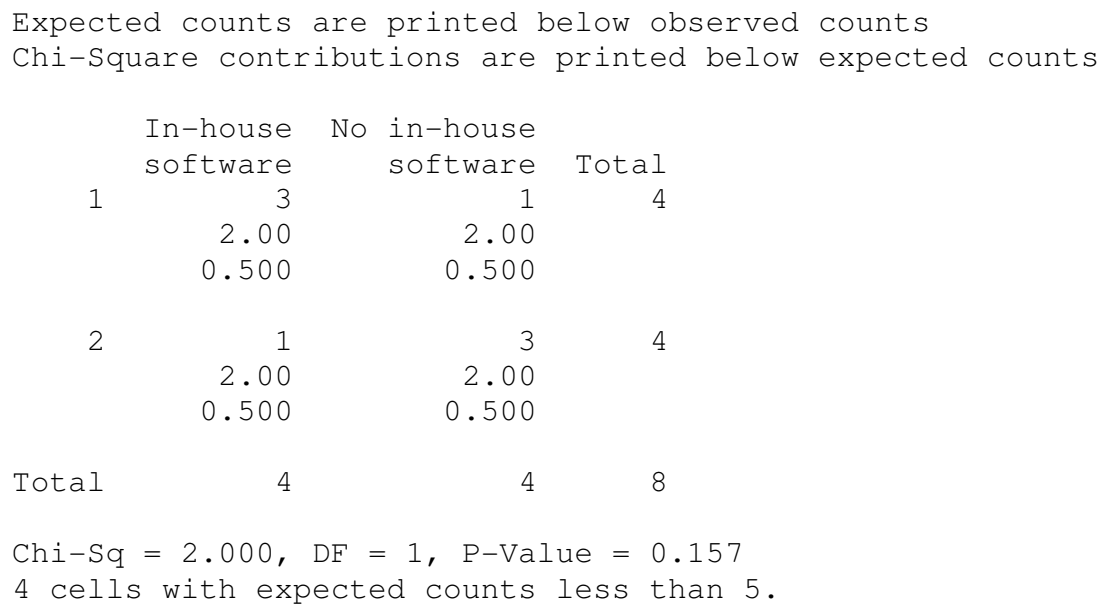

Figure 59: Chi-Square Analysis of Q27, Answer 14 with Question 24

The Chi-Square test for Answer 14 approaches significance by having a p-value of 0.157 . Figure 59 above represents the results for this analysis. Question 14 asks if electronic work instructions with color-coding, digital photos, or video are supported. A p-value of 0.157 still indicates there is no evidence to associate Question 14 with Question 27, but the analysis approaches a significance level that is closer to accepting the null hypothesis. 


\section{Chapter 5 - Summary of Important Findings}

The objective of this investigation was to identify and analyze current practices and methods used by lean manufacturing practitioners who also utilize ERP systems. Several important findings surfaced as a result of statistical analysis of the survey information:

- According to the test of proportions, populations significantly larger than $59 \%$ give initial ERP training to the manufacturing department, and populations significantly larger than $75 \%$ initially train their management and IT departments. However, populations significantly larger than $46 \%$ also indicate that top, middle, and department managers, as well as line supervisors, operators, and support staff are never given continuing education classes on ERP systems. The lean concept of continuous improvement for ERP education does not apply for almost half the population, as evident by the results.

- Populations significantly larger than $59 \%$ indicate that cost of products is monitored, tracked, and continuously improved by the ERP system, and those significantly larger than $46 \%$ indicate the same for supply delivery time. Yet seven of eight respondents, or significantly more than $59 \%$ of the population, offer only a single tier of visibility within their supply chains. Providing visibility to additional levels within the supply chain would increase the effectiveness of the chain and prevent less potential downtime due to a shortage of parts.

- Populations significantly larger than $75 \%$ indicate that the quality control departments disseminate information through email communication, and populations significantly larger than $46 \%$ indicate that the quality control department disseminates information 
through verbal/phone communication. Additionally, six out of eight companies responded by saying that quality reports are not generated automatically - either input into ERP or emailed - due to either money or training deficits, and only two of eight trained the quality department on lean concepts. A discrepancy exists with companies striving for lean operation if the majority of the organizations do not train a department integral to the successful operation of the company.

- Build to stock companies are significantly correlated with a p-value of 0.034 to not using various methods that are required in order to be considered "lean." Automated notification for material/information flowing through the manufacturing line, direct ERP links for QC departments, and automatic generation of quality reports comprise the methods not being utilized. Four out of five build to stock respondents indicated that 1$50 \%$ of each company practiced lean, confirming the significant correlation that $51-75 \%$ of each company does not practice lean.

- Assemble to order companies were strongly correlated with a p-value of 0.024 to the utilization of signals (hand, voice, electronic) for material/information flow through a manufacturing line. The same respondents were also correlated to not using the push type of manufacturing system, indicating that either a pull, push/pull hybrid, or both push and pull are used within the companies.

- Assembly companies were correlated with a p-value of 0.034 to the use of a push/pull manufacturing system within the companies. The same correlation significance also applied to having $76-90 \%$ of the company practicing lean concepts. 
- Medium-size manufacturing companies were correlated with a p-value of 0.034 to not utilizing techniques that would constitute a lean ERP system. The companies that fit into this category did not monitor, track, and continuously improve supply chain capacity with the ERP system, nor did they have automated notification for material/information flowing through the manufacturing line. Additionally, supply chain inventory was not monitored, tracked, or continuously improved by the ERP system with an even stronger significance $-\mathrm{p}=0.024$. 


\section{Chapter 6 - Conclusion}

The concept of lean ERP is at its stages of infancy. Only recently has the industry been able to understand lean manufacturing and how to apply lean to daily operations. There is a great leap from lean manufacturing to lean ERP, however. Lean ERP is a new concept that few industry professionals are talking about and even fewer are practicing. The practitioners who claim to operate as a lean enterprise have to inherently use a lean ERP, as by its own definition lean has to encompass the enterprise - yet ERP runs the enterprise. The survey results obtained for this study, and the subsequent analysis, indicate that many companies are applying lean thinking towards their ERP systems, albeit at different levels. The results show that no single company has all the elements necessary to be able to consider their ERP system truly "lean."

Very few, if any, studies have been made on the subject of lean ERP. As the literature review suggests, very few articles exist as well. The paper revises the existing body of knowledge by providing a fresh introduction of this topic to the manufacturing industry, and by asking for further, more focused research to be done. The survey was sent to lean manufacturing websites with thousands of subscribers, and directly emailed to several industry professionals. Even so, the analysis was based on a relatively small sample size, since very few people responded. However, due to the fact that the industry population practicing lean ERP is also very small, the survey sample size is comparative to that of actual industry. The survey and analysis set the framework for further exploration of the topic. Future surveys - which focus in on key aspects of lean ERP, and expand on this research - can be sent out to a much larger worldwide audience in order to capture more detailed results. Speculation suggests that manufacturing capabilities and operations would be quite different in Japan and Europe compared to the United 
States. The prevalent lean thinking and application at Japanese organizations could have inadvertently also resulted in the formation of a truly lean ERP system. Since all of the surveyed companies and websites are based in the United States, the results would not indicate such a development. However, regardless of the size and location of a business, the concept and application of lean ERP should be every company's goal in the rapidly-advancing, technologically-inclined $21^{\text {st }}$ Century. 


\section{Works Cited}

Caruso, Dave. "ERP at the crossroads, facing "lean" split." MSI (2003): 40.

Costs of Lean implementation. 7 January 2008. 7 January 2008

<http://www.sixsigmaonline.org/six_sigma_news16.html>.

Dixon, Dave. "The truce between Lean and IT." Industrial Engineer (2004): 42-45.

"Executing on lean with production IT." Manufacturing Computer Solutions (2006): 20-21.

Ford, Henry and Samuel Crowther. My Life and Work. Whitefish: Kessinger Press, 2003.

James-Moore, Mike. "ERP Implementation and Maintenance in a Lean Environment." IET

Seminar Digest (2006): 97-112.

"Lean thinking and IT do go together." Manufacturing Computer Solutions (2006): 42-43.

"Tapping into lean processess and systems." Manufacturing Computer Solutions (2006): 46-47.

Ward, Andrew. "Lean thinking and appropriate IT - Plus KPIs." Manufacturing Computer

Solutions (2005): 48-51. 


\section{Apppendix A: Lean ERP Survey}

\section{Lean ERP Survey}

Please enter the following information about yourself:

Name:

Company Name:

E-mail Address:

Telephone:

\section{General Questions}

1) What is the size of your company?

1-100 people

ᄃ 100-1,000 people

ᄃ 1,000-10,000 people

$\ulcorner\quad$ More than 10,000 people

2) What type of manufacturing best describes your company? (Select all that apply)

Assembly

$\ulcorner\quad$ Job Shop

$\ulcorner\quad$ Repetitive

$\sqsubset \quad$ Assemble to order

3) What is your company's manufacturing environment?

ए Build to stock

$\ulcorner\quad$ Build to order

4) What is your company's area of manufacturing?

Heavy industry manufacturing 
Medium size manufacturing

Small component manufacturing

\section{Lean Questions}

\section{$\underline{\text { General Questions }}$}

5) Which ERP system are you currently using?

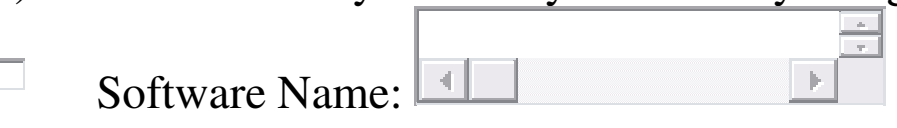

Customized in-house system

6) Is the lean concept part of the strategic plan of your company, and has the lean concept been streamlined across your company through a centralized/decentralized effort?

$\square$ Yes, the lean concept is part of the strategic plan, and it has been streamlined through a centralized effort

$\square$ Yes, the lean concept is part of the strategic plan, and it has been streamlined through a decentralized effort

$\square \quad$ Yes, the lean concept is part of the strategic plan, but it has not been streamlined

No, the lean concept is not part of the strategic plan

7) Approximately what percentage of your company is currently practicing lean concepts?

$\begin{array}{ll}\ulcorner\quad & 1-50 \% \\ \ulcorner\quad & 51-75 \% \\ \ulcorner\quad & 76-90 \% \\ \ulcorner\quad & 91-100 \%\end{array}$

8) Which lean initiatives is the company pursuing? (Select all that apply)

Definition of Value

Value Stream Mapping

Material \& Information flow analysis

Application of pull production 
$\ulcorner\quad$ Kaizen (Continuous Improvement)

Other:

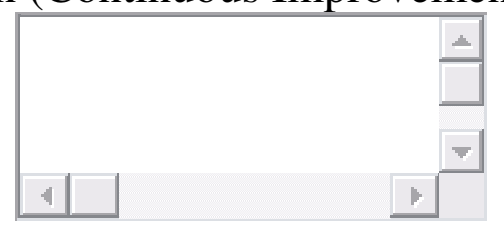

\section{Employee Training on Lean Concepts}

9) Which departments and employees were trained on lean concepts prior to the ERP conversion? (Select all that apply)

$\begin{array}{ll}\square & \text { Manufacturing } \\ \square & \text { IT } \\ \square & \text { Management } \\ \square & \text { Quality Control } \\ \square & \text { Human Resources } \\ \square & \text { Material Division } \\ \square & \text { Accounting } \\ \square & \text { Maintenance } \\ \square & \text { Top managers } \\ \square \quad & \text { Middle managers } \\ \square \quad & \text { Department managers } \\ \square \quad & \text { Line supervisors } \\ \square & \text { Operators } \\ \square \quad \text { Support Staff } \\ \square \quad \text { None of the above }\end{array}$

10) How was your lean training achieved?

$\square \quad$ Through external consultants

$\square \quad$ Internally 
11) How often do the following employees go through continuing education classes on lean concepts?

\begin{tabular}{|c|c|c|c|c|c|}
\hline Employees: & $\begin{array}{l}\text { Every } \\
\text { month }\end{array}$ & $\begin{array}{l}\text { Every } 3 \\
\text { months }\end{array}$ & $\begin{array}{l}\text { Every } 6 \\
\text { months }\end{array}$ & $\begin{array}{l}\text { Every } \\
\text { year }\end{array}$ & Never \\
\hline Top managers & $\Gamma$ & $\bar{\Gamma}$ & $\Gamma$ & $\Gamma$ & $\Gamma$ \\
\hline Middle managers & $\Gamma$ & $\Gamma$ & $\Gamma$ & $\Gamma$ & $\Gamma$ \\
\hline $\begin{array}{l}\text { Department } \\
\text { managers }\end{array}$ & $\Gamma$ & $\Gamma$ & $\Gamma$ & $\Gamma$ & $\Gamma$ \\
\hline Line supervisors & $\Gamma$ & $\bar{\Gamma}$ & $\Gamma$ & $\Gamma$ & $\Gamma$ \\
\hline Operators & $\Gamma$ & $\Gamma$ & $\Gamma$ & $\Gamma$ & $\Gamma$ \\
\hline Support staff & $\Gamma$ & $\Gamma$ & $\Gamma$ & $\Gamma$ & $\Gamma$ \\
\hline
\end{tabular}

12) Do you feel your company benefited from already having lean principles in place before implementing the ERP system?

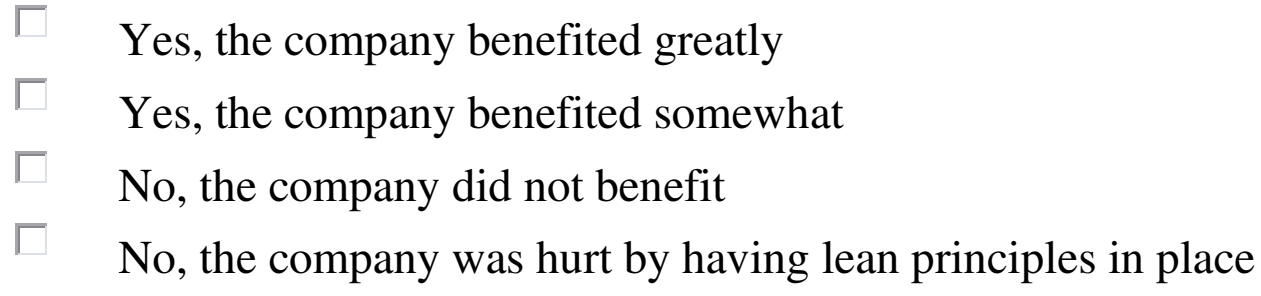

\section{ERP Questions}

\section{ERP Training}

13) What parts of the company were given training on ERP either before or after ERP implementation?

$\begin{array}{ll}\square & \text { Manufacturing } \\ \square & \text { IT } \\ \square & \text { Management } \\ \square & \text { Quality Control } \\ \square & \text { Human Resources } \\ \square & \text { Material Division } \\ \square & \text { Accounting } \\ \square & \text { Maintenance }\end{array}$


$\ulcorner\quad$ None of the above

14) How was your ERP training achieved?

$\ulcorner$ Through external consultants

$\ulcorner\quad$ Internally

15) How often do the following employees go through continuing education classes on ERP concepts?

\begin{tabular}{|c|c|c|c|c|c|}
\hline Employees: & $\begin{array}{l}\text { Every } \\
\text { month }\end{array}$ & $\begin{array}{l}\text { Every } 3 \\
\text { months }\end{array}$ & $\begin{array}{l}\text { Every } 6 \\
\text { months }\end{array}$ & $\begin{array}{l}\text { Every } \\
\text { year }\end{array}$ & Never \\
\hline Top managers & $\Gamma$ & $\Gamma$ & $\Gamma$ & \ulcorner & $\Gamma$ \\
\hline Middle managers & $\Gamma$ & $\bar{\Gamma}$ & $\Gamma$ & $\bar{\Gamma}$ & $\bar{\Gamma}$ \\
\hline $\begin{array}{l}\text { Department } \\
\text { managers }\end{array}$ & $\Gamma$ & $\bar{\Gamma}$ & $\Gamma$ & $\Gamma$ & $\Gamma$ \\
\hline Line supervisors & $\Gamma$ & $\Gamma$ & $\Gamma$ & $\Gamma$ & $\Gamma$ \\
\hline Operators & $\Gamma$ & $\Gamma$ & $\Gamma$ & $\Gamma$ & $\Gamma$ \\
\hline Support staff & $\Gamma$ & $\Gamma$ & $\Gamma$ & $\Gamma$ & $\Gamma$ \\
\hline
\end{tabular}

\section{$\underline{\text { ERP Implementation }}$}

16) Was your ERP system implemented end-to-end (total integration) or was it a partial integration of your business areas?

$\ulcorner$ End-to-end integration

$\square \quad$ Partial integration - only a certain percent of the company was included in ERP implementation (Please select below):

$\begin{array}{cc}\sqsubset & 1-50 \% \\ \square & 51-75 \% \\ \ulcorner\quad 76-90 \% \\ \ulcorner\quad 91-99 \%\end{array}$

17) How long did ERP implementation take?

Less than a year

$1-3$ years 
3-5 years

$5+$ years

18) Why were the ERP modules implemented into the ERP system?

They were deemed necessary by our company

They were recommended by the ERP consultant

They were part of the overall ERP package and could not be removed

19) Was the ERP implementation within the budget allotted, and within the time allotted?

$\ulcorner\quad$ Met the budget, met the time allotted

$\ulcorner\quad$ Met the budget, exceeded the time allotted

$\square \quad$ Exceeded the budget, met the time allotted

$\ulcorner\quad$ Exceeded the budget, exceeded the time allotted

20) If your ERP implementation exceeded the target budget, what was the cost overrun?

$\begin{array}{ll}\square & 1-25 \% \\ \square & 26-50 \% \\ \square \quad & 50-80 \% \\ \square \quad & 80-100 \% \\ \square \quad & \text { ERP implementation did not exceed the budget }\end{array}$

21) On a scale of $1-5$ boxes, with 1 box being the least cost and 5 boxes being the highest cost, rate each factor on how it contributed to the total cost of ownership of the ERP system.

\footnotetext{
$\square \square \square \square \square$ Multiple installation sites, i.e. different buildings in different locations

$\ulcorner\square \square \square \square$ Extensive hardware upgrades made to the existing computer infrastructure
$\ulcorner\square \square \square \square$ Extensive non-ERP software upgrades that support the ERP system
$\square \square \square \square \square$ Extensive training across all areas of the company
$\square \square \square \square \square$ Cost of the ERP software modules themselves




\section{ERP Operation}

22) At which levels of the organization is the ERP system being used? (Select all that apply)

Top management

Middle management

$\ulcorner$ Operation management

$\square \quad$ Supervisors

$\ulcorner\quad$ Direct labor

23) Which departments are using the ERP system? (Select all that apply)

$\begin{array}{ll}\square & \text { Manufacturing } \\ \square & \text { IT } \\ \square & \text { Management } \\ \square & \text { Quality Control } \\ \square & \text { Human Resources } \\ \square & \text { Material Division } \\ \square & \text { Accounting } \\ \square & \text { Maintenance }\end{array}$

24) Are any in-house software tools being used by your employees in order to avoid using the tools in your ERP system?
$\square \quad$ Yes
$\ulcorner\quad$ No

25) Is your ERP system capable of collecting both lean (value added) and waste (nonvalue-added) information, and does it alert the ERP system user if waste is entering the system?

$\square \quad$ It is capable of collecting both lean and waste information, and it notifies the user if waste is entering the system

It is capable of collecting both lean and waste information, but it does not notify the user if waste enters the system

26) Does your ERP system support any of the following measurements at cell, operations, and corporate levels: (Select all that apply) 
The system supports completed units per man-hour

The system supports completed units per hour

The system supports revenue per employee per unit of time

The system supports none of the above

27) Does your ERP system: (Select all that apply)

\begin{tabular}{|l|l|l|}
\hline$\cdot \quad$ Provide for continuous measurement and reporting of setup times? & \\
\hline$\cdot \quad$ Enable comparisons of actual setup time vs. planned setup time? & \\
\hline$\cdot \quad$ Include data and spreadsheets for line balancing and capacity analysis? & \\
\hline$\cdot \quad$ Provide for continuous lot size analysis? & \\
\hline$\cdot \quad$ Compare actual lot size to planned lot size? & \\
\hline$\cdot \quad$ Notify your supply chain when a visual determination reorder point is reached? & \\
\hline$\cdot \quad$ Support electronic transfer of replenishment signals? & \\
\hline$\cdot \quad$ Support electronic printing and posting of kanban signals? & \\
\hline$\cdot \quad$ Support automatic capture of line/cell production completion times? & \\
\hline$\cdot \quad \begin{array}{l}\text { Offer real-time measurement of performance to takt time? (takt time is equal to } \\
\text { time allotted to manufacture a product in order to meet demand) }\end{array}$ & $\square$ \\
\hline$\cdot \quad$ Include spreadsheets for calculating line/load balance and total labor \\
requirements?
\end{tabular}




\begin{tabular}{|ll|l|}
$\cdot \quad$ Support effective, custom measurement of the cost of quality $?$ & \ulcorner \\
\hline$\cdot \quad$ Support a direct measurement of lead time reductions? & $\square$ \\
\hline$\cdot \quad$ Compare actual lead time vs. planned lead time? & $\square$ \\
\hline
\end{tabular}

\section{ERP Questions for Specific Business Areas}

\section{Management}

28) How do managers use the ERP system in your company? (Select all that apply)

Track finances

$\ulcorner\quad$ Track scheduling operations

$\square \quad$ Record historical data

$\ulcorner\quad$ Track communications

$\square \quad$ Forecast future sales

$\ulcorner\quad$ Exception reporting

$\square \quad$ Production reporting

$\ulcorner\quad$ Customer delivery performance reporting

$\ulcorner\quad$ Master schedule performance reporting

$\ulcorner\quad$ Manufacturing operations performance reporting

$\sqsubset \quad$ Supply chain performance reporting

$\ulcorner$ Other:

29) How is manager-specific information stored after the ERP system has been implemented? (Select all that apply) business

Information is manually entered by employees in non-managerial areas of the $\ulcorner$ Information is automatically collected from non-managerial areas of the business

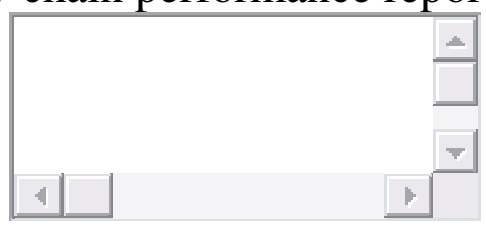

Managers manually enter the information 
30) How do managers improve the efficiency of their daily operations through ERP? (Select all that apply)

$\square \quad$ Organize tasks more efficiently through use of the ERP's scheduling system Automate tasks through the use of the ERP's automation system Incrementally perform manual tasks faster, without utilizing the ERP system Do not attempt to improve the efficiency of their daily operations

\section{Information Technology (IT)}

31) Do you have a IT database, and is it part of the ERP package?

Yes, we have a IT database and it is part of the ERP package

Yes, we have a IT database but it is not part of the ERP package

No, we do not have an IT database.

32) How are incoming IT problems handled by the ERP system?

They are emailed by the request initiator, and IT enters them into the IT database

The request initiator enters the incoming request into the IT database

They are emailed and exist only as an email, there is no IT database

They are conveyed through a different method (paper forms, phone calls, etc.)

33) On a scale of 1-5, with 1 being the smallest and 5 being the highest difficulty, how hard is it for you to incorporate additional ERP modules into the current ERP system?

$\begin{array}{ll}\sqsubset & 1 \\ \sqsubset & 2 \\ \sqsubset & 3 \\ \ulcorner & 4 \\ \ulcorner & 5\end{array}$

\section{$\underline{\text { Supply Chain }}$}

34) Does your ERP system have electronic communication capability with your supply chain companies? 


\section{$\square \quad$ Yes \\ No}

35) Which of the following elements of the supply chain are monitored, tracked, and continuously improved by the ERP system? (Select all that apply)
$\square \quad$ Supply delivery time
$\ulcorner\quad$ Quantity of products delivered
- Type of products delivered
$\square \quad$ Quality of products
$\square \quad$ Cost of products
$\square \quad$ Flexibility/responsiveness of the company
$\ulcorner\quad$ Inventory
$\ulcorner$ Capacity

36) What level of visibility is offered by your ERP system?

$\square \quad$ Only on our suppliers (1 tier)

$\sqsubset \quad$ At our supplier's suppliers (2 tiers)

$\ulcorner\quad$ At our supplier's suppliers' suppliers (3 tiers)

37) What percentage of your supply chain companies interact with your ERP system?

\section{ㅁore than $90 \%$}

ए 70-90\%

Г 50-70\%

$\ulcorner\quad$ Less than $50 \%$

38) How is information input into the supply chain section of the ERP system? (Select all that apply)

$\square \quad$ By the workers

$\square \quad$ By the machines (automated)

$\square \quad$ By the suppliers

$\ulcorner\quad$ By the suppliers' suppliers

39) If "machines" was selected above, what percentage of your supply chain information input is performed automatically? 


$\begin{array}{ll}\ulcorner & 1-50 \% \\ \ulcorner\quad & 51-80 \% \\ \ulcorner\quad & 81-95 \% \\ \square \quad 96-100 \%\end{array}$

\section{Manufacturing}

40) What kind of shop layout do you have at your manufacturing facility? (Select all that apply)

\section{Cellular}

$\ulcorner\quad$ Line

$\ulcorner\quad$ Function / traditional job shop

41) Are you currently on a Push or Pull type of manufacturing system?

$$
\begin{array}{ll}
\square & \text { Push } \\
\square \quad \text { Pull } \\
\square \quad \text { Push/pull hybrid } \\
\square \quad \text { Both types, but separate manufacturing lines }
\end{array}
$$

42) How does material and information flow throughout the manufacturing line?

Utilization of Kanban cards

$\ulcorner\quad$ Utilization of signals (hand, voice, electronic)

$\square \quad$ Automated (computerize notification

$\ulcorner\quad$ Utilizing a dispatch list including MRP generated orders

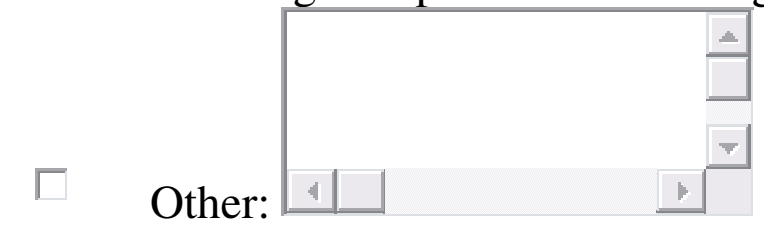

43) How is production information collected throughout the manufacturing line?

$$
\text { Machines are linked directly with the ERP software system }
$$

$\square \quad$ Operators enter information directly into the ERP software system

$\ulcorner$ Operators write information down, then enter it into the system later 
Some or all information collection is paper-based, and ERP is not used

\section{Quality Control (QC)}

44) How does QC collect and disseminate information /audit results with different departments? (Select all that apply)

Direct ERP link with other departments

$\square \quad$ Through email communication

$\ulcorner\quad$ Through verbal / phone communication

$\ulcorner\quad$ Through paper communication

$\ulcorner\quad$ Through automated communication (computer-generated)

45) How often are quality reports generated?
$\square$ Daily
$\square \quad$ Weekly
$\square \quad$ Monthly
$\ulcorner$ Quarterly

46) Are the quality reports generated automatically or manually?

Automatically (input into ERP or email)

$\ulcorner\quad$ Manually, because the staff is not trained to perform the work through automatic means

$\ulcorner\quad$ Manually, because there is not enough monetary resources to perform the work through automatic means

$\ulcorner\quad$ Manually, because the reports are generated faster through automatic means

\section{Accounting}

47) Are accounting reports generated automatically via ERP or a stand-alone accounting package?

$\ulcorner\quad$ Reports are generated automatically via ERP

$\ulcorner\quad$ Reports are generated automatically via a stand-alone accounting package

$\ulcorner\quad$ Reports are not generated automatically 
48) By what means do the reports reach the recipients? (Select all that apply)

$\square \quad$ Automatically sent by ERP or email system

$\ulcorner\quad$ Manually emailed

$\square \quad$ Through the company's inter-office mail system

$\ulcorner\quad$ Hand-delivered to every recipient

49) If reports are handled manually, why aren't the reports sent through electronic means?

They haven't been formatted for electronic distribution

$\square \quad$ The company likes to have a paper trail of every report

$\ulcorner\quad$ The company hasn't looked into electronically distributing the reports

50) Is your ERP system capable of improving any of the following: (Select all that can be improved)
$\ulcorner\quad$ Reducing the number of reports generated
$\square \quad$ Reducing the amount of time it takes to generate a report
$\ulcorner\quad$ Reducing the number of people producing reports
$\ulcorner\quad$ Increasing the percentage of electronically generated reports
$\sqsubset \quad$ Increasing the percentage of automated report generation

\section{Human Resources (HR)}

51) How does HR utilize ERP? (Select all that apply)

ㄷeps track of employee payroll

Keeps track of employee applications and other forms

$\square \quad$ Keeps track of employee benefits

$\ulcorner\quad$ HR does not utilize the ERP system

52) How does HR obtain information that goes into the system? (Select all that apply)

By entering information manually from a paper source

By entering information manually from an electronic source

By automated information collection using the ERP system 
53) What aspects of HR are currently being improved through ERP? (Select all that apply)

They are becoming more efficient in processing forms

They are automating menial tasks that can be handled by the computer

$\square \quad$ They are reducing the number of forms needed to perform the same action

$\ulcorner\quad$ They are not actively improving any aspect of the department

\section{Customer Relations Management (CRM)}

54) Does the ERP system have a module that handles your customer relations management system?

$\sqsubset \quad$ Yes
$\ulcorner\quad$ No

55) If "Yes" to the question above, does the ERP system automatically respond to outside customers' requests for quantity, timing, and flexibility changes?

$\ulcorner\quad$ Yes
$\ulcorner\quad$ No

Thank you for taking the time to fill out this survey. Would you like a copy of the results?

$\ulcorner\quad$ Yes, I would like a copy of the results.

$\ulcorner\quad$ No thank you, I would not like a copy of the results.

Comments about the survey: 


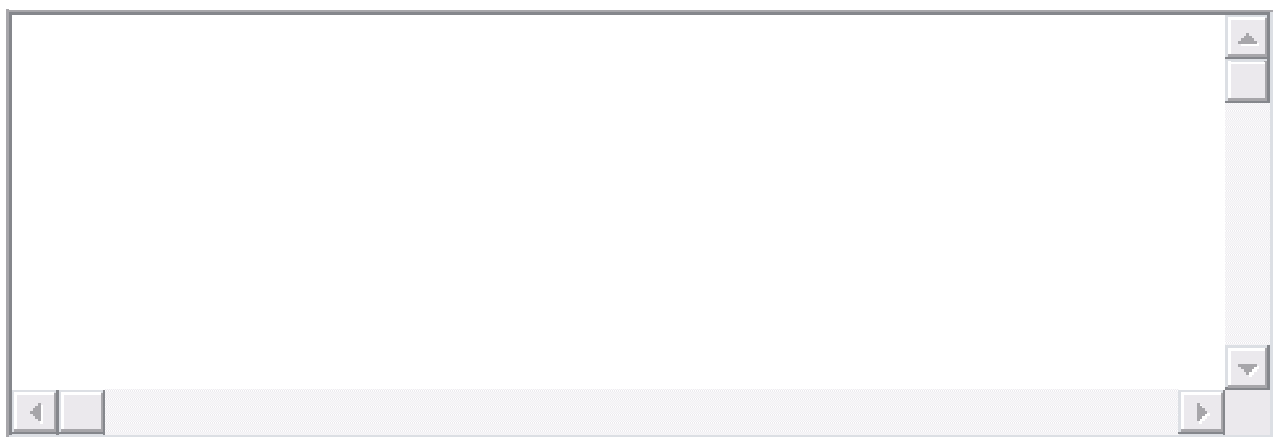

If you are ready to submit the survey, please type "Yes" into the field below. The field is used to prevent a partial submission of the survey by an accidental click of the Enter key.

Ready to submit?

Please make sure to click "Send" only once so survey results are not double counted.

...or Reset the Form

